\title{
Reflections on the term Micoquian in Western and Central Europe. Change in criteria, changed deductions, change in meaning, and its significance for current research
}

\author{
Jens Axel Frick ${ }^{1,2}$ (D) \\ Received: 15 July 2019 / Accepted: 28 November 2019 / Published online: 18 January 2020 \\ (C) The Author(s) 2020
}

\begin{abstract}
The primary objective of this contribution is to show the intricate ways of over 100 years of research concerning the term Micoquian and its multiple shifts in meaning. A detailed analysis of the course of the research history has made it possible to identify several tendencies of shifting meaning. This concerned both its position within the chronology, its spatial extent, and decisive assemblage components. The term Micoquian has been used to describe complexes with very different characteristics. Chronologically, both assemblages dating before, during, and after the last interglacial period were referred to as Micoquian. To avoid difficulties in understanding the term, different names for the generic units of the respective assemblage units have been proposed from time to time. Due to the reflections on the research history, it is possible to investigate the question of whether and to what extent the term Micoquian should continue to be used and what significance is attached to it today, and to what extent it appears necessary to pursue other approaches to the classification of the Middle Paleolithic record. In conclusion, a multidisciplinary approach is proposed (including lithic, faunal, radiometric, site catchment, and/or settlement dynamic analysis) to build a multifaceted framework that is able to form clusters of similarities. The formerly defined generic units (called technocomplexes, facies, groups, space-time units, and so on) are seen purely as umbrella terms to structure the Paleolithic record, without claiming to reflect the former Paleolithic reality. With the addition of a tight chronological corset, the definitions of technocomplexes (by using lithic, faunal, and possibly floral data) could allow small, manageable space-time units to be formed and then compared with one another.
\end{abstract}

Keywords Micoquien $\cdot$ Micoquian $\cdot$ Faustkeilschaberinventare $\cdot$ Keilmessergruppen $\cdot$ Micoquo-Prondnikian $\cdot$ Bocksteinkultur

\section{Introduction}

This article examines the research history of the term Micoquian. It contributes to the discussion of chronological-

This article is part of the Topical Collection on Settlement Patterns Dynamics of the Middle Paleolithic and Middle Stone Age

Jens Axel Frick

jens-axel.frick@ifu.uni-tuebingen.de

1 Department of Early Prehistory and Quaternary Ecology, Institute for Pre- and Early History and Medieval Archaeology, Eberhard Karls University of Tübingen, Schloss Hohentübingen, Burgsteige 11, 72070 Tübingen, Germany

2 Projet collectif de recherche (PCR), "Le Paléolithique supérieur ancien en Bourgogne méridionale" associated with UMR 6298 ARTeHIS at the Université de Bourgogne, Dijon, France spatial units in Paleolithic research and discusses the varying uses of the term in the context of over 100 years of research.

On the whole, the majority of researchers have increasingly narrowed down the term chronologically. However, tendencies toward the use of long chronologies can also be observed occasionally. At times, the term Micoquian was charged with very different, incompatible meanings, which led to a parallel use and made it difficult to give a uniform definition. The generic units defined in this way are sometimes spatially or temporally separated from each other, but are nevertheless assigned the same term, a phenomenon that can also be observed for other chrono-spatial units (e.g., the Mousterian facies of Bordes).

Sometimes ambiguity is countered by trying to define new terms for a generic unit. New definitions occasionally use different basic components for definition, although the same name is used for the generic unit. The reverse case can also be observed. In contrast to biological taxonomy (e.g., McCarthy 1995), there is no recognized set of rules on the basis of which 
it is possible to provide the phenomena recognized in Paleolithic research with a uniform name.

The definition of the term technocomplex represents an attempt to taxonomically structure the archeological material (Clarke 1968, pp. 328-329): "These grosser entities involve groups of cultures which are not related or collateral cultures but which do share polythetic complexes of type families on the basis of common factors in environment, economy and technology. Since it is extremely difficult to discuss an entity without a name let us tentatively call these gross groupings technocomplexes. [...] The technocomplex represents the partly independent arrival of diverse developing culture systems at the same general equilibrium pattern based on a similar economic strategy, in similar environments with a similar technology and a similar trajectory." (emphasis added by the author). Let us summarize this definition of technocomplexes as follows: (Lithic) assemblages that share the same economic strategy, in similar environments with a similar technology and a similar trajectory (see also Frick 2016, pp. 85-87).

The formation of chrono-spatial units in Paleolithic research was and is mainly based on stone artifacts, since their large quantity and generally good preservation allow phenomena to be observed in space and time. With regard to the generic unit of the Micoquian, bifacial lithic objects were and are mostly used as the main criterion for classification.

In the course of the research history, it is easy to observe how the reference system, the systematic approach to these pieces, changed. At the beginning of research, individual lithic index fossils were decisive for the assignment to a generic unit (Mortillet 1873), which could separate coarse bifaces (Acheulian) from more finely made bifaces (Mousterian). The typological approach established by Bordes tried to ensure a higher objectivity by using a larger selection of pieces within an assemblage. Although bifacial pieces were measured here, they were still evaluated qualitatively (Bordes 1953a, b; Bordes and Bourgon 1951). The technological lithic investigations, which were intensified from the 1980 s onwards, provided deep insights into the production process of the pieces (Tixier et al. 1980). As a result, the previously determined lithic types lost their static character, since their great mutability was shown by the extraction of reworking and remolding processes. The limiting factor is that in many cases these three approaches mix and only detailed restudies show how attempts were made to classify the existing material. Particular methodological approaches are already presented in early work, which have become popular later on.

We investigate how the term Micoquian, including alternative terms and synonyms, was used in the course of research below. In order to make the shifts in meaning visible, an attempt will then be made to analyze them over time in order to show the different ways in which the term has been and is used in research. We will also examine the question of whether, given the current state of research, it might make sense to continue to use such a superordinate cluster, the so-called generic unit.

\section{Earliest definitions}

In the search for the origins of the term Micoquian, one comes across the dissertation of Hauser (1916). However, the term was already used earlier by different authors. In this early phase, the term was used primarily in direct relation to the La Micoque site. First, the term was used as an adjective (micoquien, micoquienne) to describe corresponding phenomena of the La Micoque site. Convincingly, here are the classifications of bifaces, for example:

- Peyrony (1908): pointes micoquiennes [Micoquian points] - Obermaier (1908a): Reduzierter lanzenspitzförmiger Faustkeil vom Typus von La Micoque or Micoquekeil [Reduced lance-shaped biface of the La Micoque type or Micoquian biface]

- Schmidt (1912b): Langausgezogener, lanzenspitzförmiger Fäustel vom Typus La Micoque [Long extended, lanceolate biface of the La Micoque type]

- Hauser (1916): Micoque-Keil-Spitze [Micoquian wedge point]

These, however, make it clear that even at the beginning of the research at this site, unusual lithic pieces (deviating from the known norm) enjoyed special attention. The question of what can be addressed as Micoquian biface will be encountered frequently below.

Let us now return first to the site of La Micoque, discovered in 1895 and first excavated by Chauvet and Rivière in the following year (Capitan 1896a, b; Chauvet 1896; Chauvet and Rivière 1896, 1898). Subsequently, further researchers undertook excavations at the site (Peyrony, Coutil, Cartaillhac, Hauser, Bordes, Laville, Rigaud, and Debénath). Rosendahl (2004, 2006, 2011) has summarized the extensive research history of the site, and therefore, it is not repeated here.

The term Micoquien itself, for a generic unit (initially related only to La Micoque) was used by Hauser years before his dissertation: ,[...] das "Micoquien", wie ich bereits 1907 den Sondertypus der auf dieser Station gefundenen, bis jetzt von der Prähistorie dem Acheuléen (Obermaier) bzw. einem warmen Moustérien (Wiegers) zugewiesenen Artefakte genannt habe, eine Sonderkultur der dritten Interglazialzeit darstellt, [...].“ (Hauser 1915, p. 443) [the "Micoquien," as I already called the special type of artifacts found on this station in 1907, assigned to the Acheulian (Obermaier) or to a warm Mousterian (Wiegers) by prehistoric research until now, a special culture of the third interglacial period].

The earliest extensive descriptive and written reference to the term for a spatial-temporal unit was most probably made 
by Hauser (1916). However, he already used it in two ways (Hauser 1916, p. 55). On the one hand, he used the term to describe all archeological remains found in La Micoque under his direction; on the other hand, he used the term to describe numerous sites in Central Europe (German Micoquian). Chronologically, he regarded the Micoquian between the Mousterian and the Aurignacian and justified this on the grounds that the assemblage he regarded as Micoquian was a mixture of Acheul-like, Moustier-like, and Aurignac-like types; see also, Hauser (1916, p. 55).

This was contradicted by the assumption of $\mathrm{H}$. Obermaier, who saw the industry of La Micoque as a subgroup of the late Acheulian (Obermaier 1908a, b, 1912, pp. 128-129; 1924, pp. 8-9). Moreover, the finds were already assigned to the Acheulian within the first excavations, before Obermaier and Hauser described them (Capitan 1896a, b).

Chronologically, the Micoquian was assigned to an interglacial, with Obermaier, Hauser, and Wiegers agreeing. However, the allocation to larger units was different. Obermaier suggested an affiliation to the Acheulian (Obermaier 1908a), Hauser saw a positioning between the Mousterian and Aurignacian (Hauser 1916), and Wiegers placed the Western and Central European Micoquian in the "warm Mousterian" defined by him (Wiegers 1920, 1928).

Both Obermaier (1912, pp. 129-130) and Wiegers et al. (1913, p. 134) have examined the finds from La Micoque in detail, but arrive at completely different conclusions, mainly due to their different approaches. While Obermaier emphasizes the Acheul character (referring to the bifacial pieces and the outline of tools), Wiegers focuses on the Mousterian character (referring to the unifacial components, the cross-section, and blanks) of the finds (see also Weißmüller 1995, p. 40).

In this context, the fact that Hauser as a person was considered controversial during his work in the Vézère valley must be taken into account. The literature of this period includes both defamation (Bégouën 1915a, b; Boule 1915a, 1916a, b, c; CroMagnon 1915; Obermaier 1908b; Verneau 1915) and support for the excavation work and the subsequent doctoral thesis (Bayer 1920; Birkner 1918a, b; Boule 1915b; Hörmann 1916; Mortillet 1907; Werth 1916a, b, 1919). Through this fame, the concept of the Micoquian spread more and more. A total of three positions can thus be identified for the late 1910s:

- The Micoquian is an independent unit, located between Mousterian and Aurignacian, and is chronologically assigned to an interglacial period (Hauser).

- The Micoquian is part of the Acheulian, temporally between the early Acheulian and the Mousterian and is chronologically assigned to an interglacial period (Obermaier).

- The Micoquien is part of the Mousterian, temporally located between the Acheulian and the cold Mousterian, and is chronologically assigned to an interglacial period (Wiegers).
In the 1910 s already, numerous sites in France (Baudouin 1913; Birkner 1918a; Hauser 1916; Schmidt 1911, 1912a) and Germany (Birkner 1918a; Hauser 1916; Hörmann 1916) were assigned to the Micoquian. In the 1920s, sites were added from Great Britain (Breuil 1926) and Poland (Kozłowski 1924) (see Fig. 1).

Toward the end of the 1920s, Hauser (1928) himself recorded a total of $n=116$ sites throughout Europe and even in Central Asia, the Middle East, and Central Africa, which he assigned to the Micoquian. If one compares the distribution of Micoquian sites according to Obermaier (1908a) in Western Europe and Kozłowski (1924) in Central Europe, Hauser's distribution map can be regarded as vastly unrealistic (see also Fig. 2). However, this only applies if rough criteria are used for the assignment of an assemblage to the Micoquian (or any other generic unit).

In the 1910 s and early 1920 s, the Micoquian was uniformly assigned to an interglacial period, although the cultural assignment (generic unit) sometimes differed greatly (see Fig. 3). The use of the Micoquian biface as index fossil for the respective allocation remained uniform here.

\section{Generic unit}

At this point, let us briefly specify what we mean by the term generic unit. Since terms such as Micoquian, Mousterian, Acheulian, and others (and in all their spellings) are not uniformly regarded as a term for a specific unit (in space and time), the term generic unit is used, which very generally implies a supposed connection within a common term. Thus, the generic unit is regarded as an umbrella term under which, depending on the approach, different phenomena or characteristics of an artifact or assemblage can be united. We see this as a way of dealing with the fact that very different definitions of the same term can be presented and examined. Thus, a generic unit can reflect a technocomplex, a facies, a group, a space-time unit, a cultural group, a cluster of sites, etc.

\section{Research in the course of the 1920s}

It already became apparent in the 1920s that the chronological position of assemblages, that were referred to as Micoquian, cannot always be clearly located in the Interglacial, even when Obermaier's industrial definitions were applied instead of Hauser's. The best example of this is Kozłowski's (1924) explanations of Polish sites, which were placed in the early Würm. One could see this as the starting point where the research community began to use the term Micoquian on the basis of different definitions, not necessarily according to the artifact addressed, but according to the supposed chronological position. This is clearly visible when the approaches of Breuil (1926, 1932a, b) and Riek (1934) are juxtaposed. On the basis of Peyrony's 

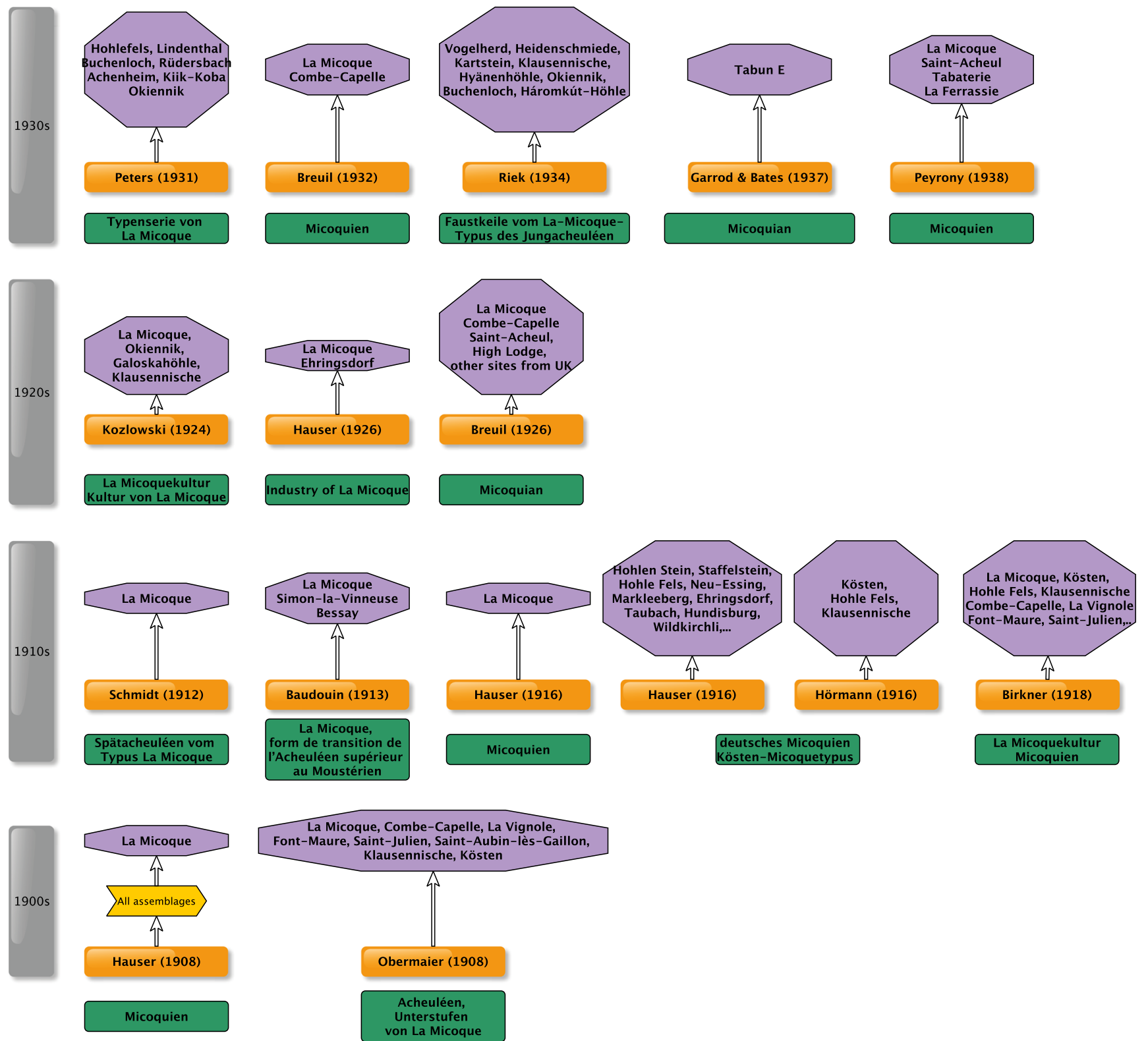

Fig. 1 Cladogram of the term Micoquian and closely related terms (1908-1926). The use of the term, or related terms, is clearly visible here, either solely for the La Micoque site or with the addition of further sites (here: independent of which layers in La Micoque are called Micoquian)

(1930, 1933, 1938) excavations in 1929, Breuil narrowed the term Micoquien to the layer N/6 in La Micoque. He proposed a branched system of complexes that followed each other in time or were parallel to each other, whereby the Micoquian originated from the Acheulian (the hypothesis of Obermaier) and merged into numerous other mousteroid industries (see Fig. 3).

In contrast, Riek (1934) used the term Micoquian for occupations after the Interglacial (as Kozłowski 1924 did), but designated in clearly as part of the Upper Acheulian (as Kozłowski 1924; and Obermaier 1924 did). Riek quoted the work of Kozłowski (in relation to the Aurignacian), but for the Micoquian he followed Obermaier's explanations and assigned the Micoquian to the Upper Acheulian.
The naming of independent complexes was also a controversial issue in the 1920 s and 1930 s, with both factual (Menghin 1926) and polemical national (Andree 1930) arguments being put forward. At the beginning of the 1930s, the term Micoquian was used for two different units. Firstly, Breuil's definitions were used in francophone countries, and secondly, researcher from Poland and Germany used their own definitions. Since the Micoquian biface continued to be used as the defining element, the definitions differed mainly in the chronological location of the assemblages. The German and Polish assemblages (early Würm), for example, were estimated to be much younger than similar sites in France (last interglacial). 


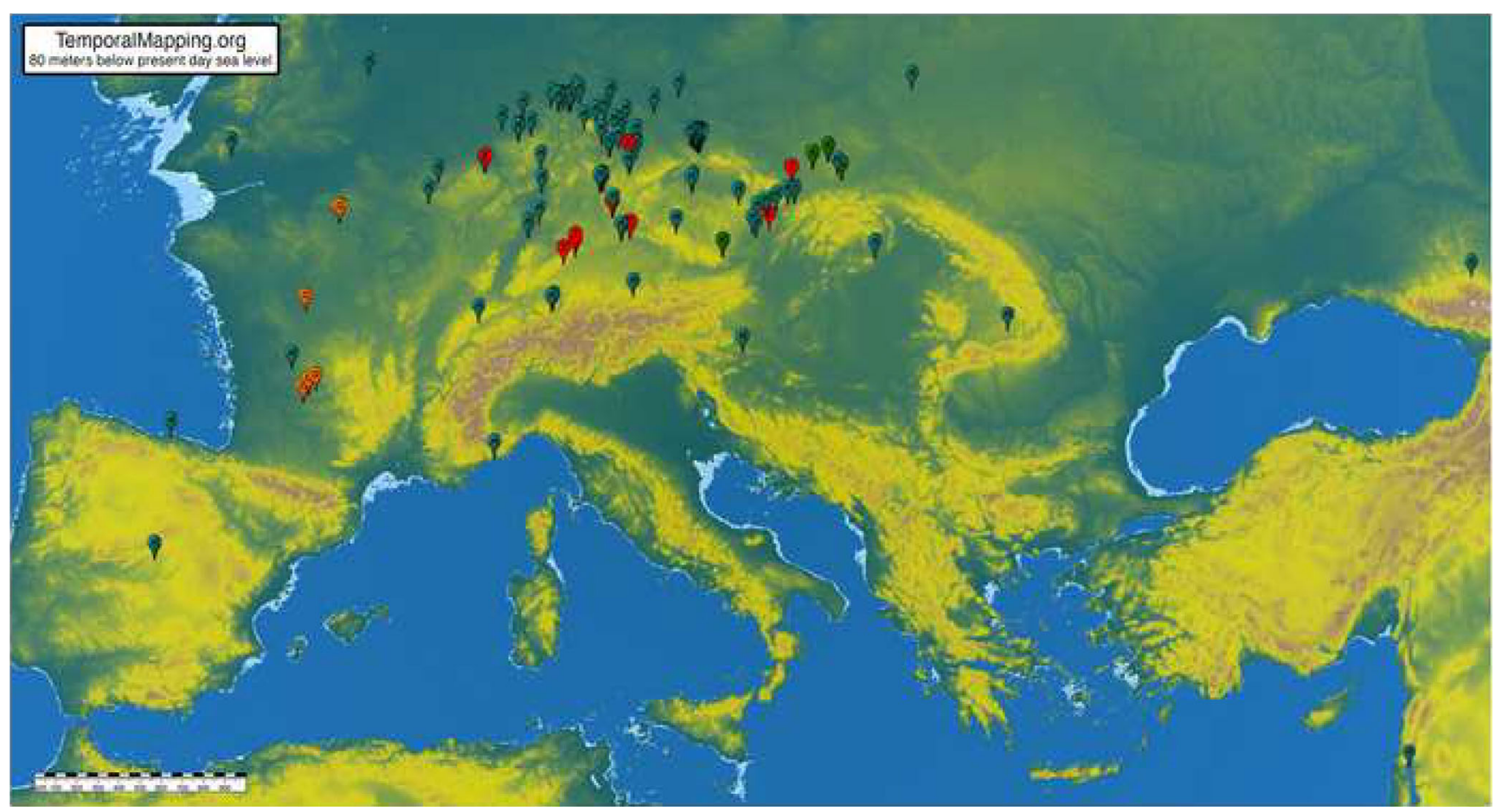

Fig. 2 Map of sites attributed to the Micoquian: orange markings with $\mathrm{O}$ (Unterstufe von La Micoque, lokale Fazies des jüngeren Acheuléen), according to Obermaier (1908a), green markings with $\mathrm{K}$ ( $\mathrm{La}$ Micoquekultur), according to Kozłowski (1924); petrol markings with $\mathrm{H}$ (Artefakt- u. Menschfundorte des Micoquien), according to Hauser
(1928); and red markings with $Z$ (distribution of sites attributed to the Micoquian), according to Zotz (1951). Base maps from TemporalMapping.org ( $80 \mathrm{~m}$ below present-day sea level) from GoogleEarth Pro

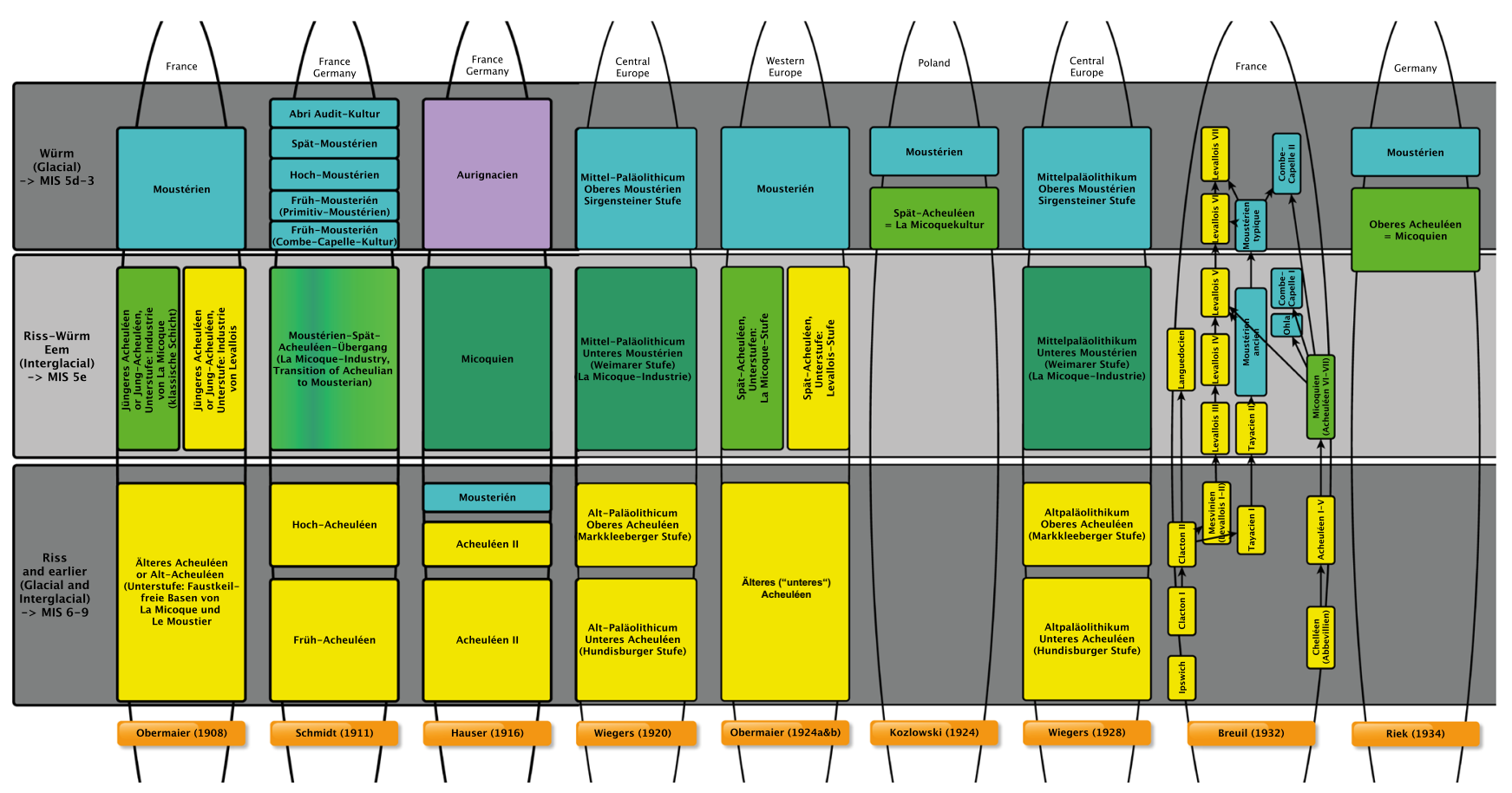

Fig. 3 Cladogram of the chronological positioning of the term Micoquian (1908-1934). For an overview of the diversity of the assignment of the Micoquian, the considerations of Obermaier (1908a), Schmidt (1911), Hauser (1916), Wiegers (1920), Obermaier (1924), Kozłowski (1924), Wiegers (1928), Breuil (1932b), and Riek (1934) are outlined here.
Color code: yellow (Lower Paleolithic, Acheulian), light green (Micoquian as part of the Acheulian), green gradient (Micoquian is Acheulian or Middle Paleolithic), dark green (Micoquian as part of the Middle Paleolithic), blue (Mousterian or Middle Paleolithic), and violet (Upper Paleolithic) 


\section{Research of the 1930s and 1940s}

During the 1930s and 1940s, the Micoquian became an integral part of chrono-cultural terminology and was used for numerous industries in Eurasia and Africa, as the following examples show. As with other industries, affiliation was determined on the basis of index fossils. For the Micoquian, the presence of Micoquekeile [Micoquian bifaces], and those similar enough, according to the researchers, to be determined as such, became the primary determining element.

The first example is the Kiik-Koba site on Crimea, which was described with a La Micoque affinity from the late 1920s onwards due to the bifacial pieces (Bonč-Osmolovskij 1929; Golomshtok 1938), but which was criticized at the same time (Zamiatnin 1929). Furthermore, the layer E in Tabun, which was called Micoquian in its first description, deserves mention (Breuil 1938; Garrod et al. 1937). Another example is Stellenbosch in South Africa, where the upper layers were compared to the Micoquian (Grenier 1945), similar to other sites in Southern Africa (Breuil 1930) or the Wadi Kom Ombo in Egypt (Vignard 1945). In that time, it also became increasingly apparent that the term developed a life of its own, so to speak: the meanings of what was to be understood by the term became more and more different. For this reason, Zamiatnin (1929, p. 293) writes that sites from Germany, Austria, Moravia, Poland, Hungary, TransylvaniaI, Crimea, and the North Caucasus are part of this "culture," whereby these sites are spread over a large area and do not have any contemporaneity.

While industries attributed to the early Würm and showing micoquoid elements in Central Europe were referred to as Micoquian, in Western Europe, the industries attributed to this unit were considered older and attributed to the Interglacial or the period before. For example, in Germany, the postinterglacial layers (layer 8, later named layer h) of Bocksteinschmiede (Wetzel 1944, p. 90; Wetzel et al. 1941), like the lowest layers of Vogelherd (Riek 1934), were assigned to the Micoquian. The important finds of Bocksteinschmiede were also acknowledged in a review by Zotz (1941), who emphasized the micoquoid character of the finds.

In addition to the common use of the established French terms for generic units, which originated from the Mortillet's school (e.g., Mortillet 1869, 1873; Mortillet 1883) and was modified and extended by numerous researchers (e.g., Breuil 1932b; Peyrony 1921), German researchers tried to introduce their own terms (Andree 1930, 1939; Menghin 1926, 1931; Wiegers 1920, 1928). Some of these different approaches are illustrated (Fig. 4).

In exceptional cases, researchers went so far as to completely reject established systems and attempted to develop independent chronological systems. Andree's (1939) system (see Fig. 4) is a good example of how approval or rejection took place within language (attitude) boundaries. Andree suggested that the units envisaged by Wiegers and Menghin should only be considered suitable and valid for Germany. Like Wiegers, he considered Paleolithic research to be a geological discipline that had to base its chronology mainly on geological observations. If the term culture is replaced by industry in the following statement, it can be endorsed to a large extent even today: "Es ist also nicht angängig zu sagen, $\mathrm{da} ß$ in einem bestimmten Zeitabschnitt nur eine ganz bestimmte Kultur auftreten könne oder daß alle Funde aus einer bestimmten Zeit zu einer einzigen Kultur gehören müssen." (Andree 1939, p. 140) [Thus, it is not appropriate to say that in a certain period of time only a certain culture (industry) can appear or that all finds from a certain time must belong to a single culture (industry)]. Andree adopted Wiegers' division of the generic units: Faustkeilkulturen [Biface cultures], Breitklingenkulturen [Broad blade cultures], and Schmalklingenkulturen [Narrow blade cultures] and rejected Menghin's terms (Protolithic, Miolithic, and Neolithic), since they only represent new names for applicable units. Based on an index fossil approach, he suggested the following hypothesis regarding the classification of German assemblages (Andree 1939, p. 142): hand points (Handspitzen-), leaf points (Blattspitzen-), and blades cultures (Klingenkulturen).

Broadly speaking, this approach and its terminology are plausible as well. At this point, however, the difficulty begins in understanding what is meant by these terms and of what types are referred to as such. According to Andree's (1939, p. 142) descriptions, the greatest difficulty lies with the term hand point [Handspitze], because these pieces can be produced both unifacially and bifacially and can be made from blanks or raw pieces. In the case of very large pieces, the term large point [Großspitze] is used. The chronologicalgeological framework for the hand point cultures covers the period between the Günz-Mindel-Interglacial and the early Würm and had to be seen as a step backwards even in the 1930s, since there already were much finer subdivisions, which enjoyed a certain geochronological certainty in individual cases. In order to further complicate the classifications, Andree also mentions the Western European Biface culture [Faustkeilkulturen], including a larger biface and a scraper from the Neanderthal (Andree 1939, p. 569). He completely contradicts the tripartite division of the Biface culture according to Zotz (1939) and tries to prove that assemblages from its middle stage are actually located in the Saale (Riss) glacial, Saale-Weichsel (Riss-Würm) interglacial, and Weichsel (Würm) glacial (Andree 1939, p. 576). Here, the Nordic chronological system is chosen to structure the ice ages for the whole of Central Europe, in contrast to the system established by Penck and Brückner (1909) for the Alpine region. As Weinert (1939) pointed out, in this context, the cultural sequence established by Mortillet is not indispensable for the Central European region and the time before the Upper Paleolithic. Even though Zotz's temporal division is no longer 


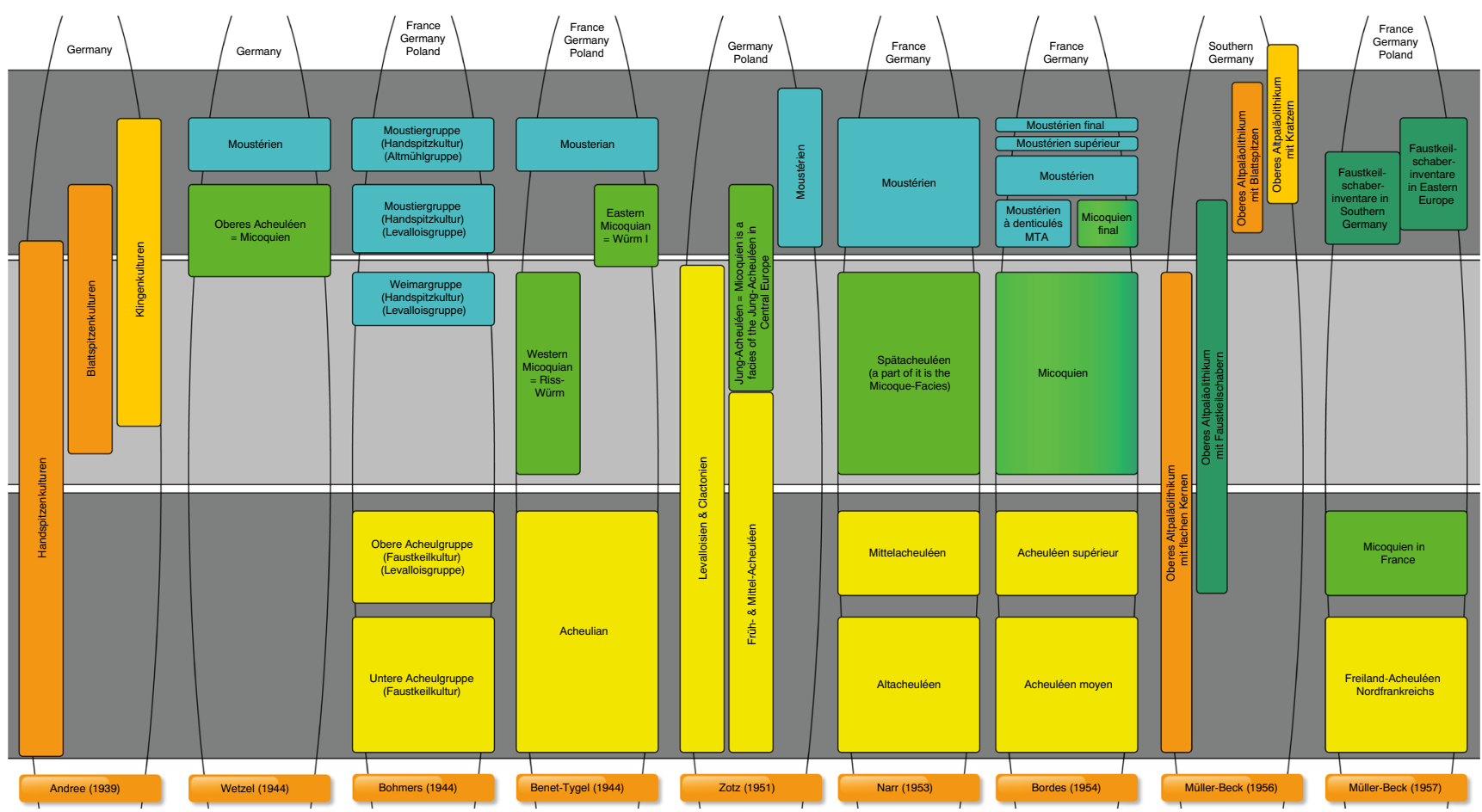

Fig. 4 Comparison of the chronological sequence of generic units proposed by various authors in the end of the 1930s to 1950s. For comparison, the approaches of Andree (1939), Wetzel (1944), Bohmers (1944), Zotz (1951), Narr (1953), Bordes (1954), and Müller-Beck (1956, 1957) are compared. Color code: yellow (Lower Paleolithic, Acheulian),

tenable today, Andree's division of the assemblages was even more imprecise and completely contradicted the results obtained until then.

This can also be seen in numerous reviews of his book. Grahmann (1940, pp. 188-189) writes that Andree's classification scheme provides developmental lines at best, but no chronological stages. Pittioni (1939, p. 452) also comments on the different structures of the archeological material and that terminological issues have always been delicate, since several different names for the same object have always created confusion. McBurney (1950), too, spoke about the typology used by Andree (1939) and did not find it useful for comparison: "Unfortunately this last [contribution], though of crucial importance from a geographical point of view, is rendered a good deal less useful than it might otherwise have been by the author's very novel typological classification."

While Andree and other authors introduced terms for Paleolithic generic complexes, German Paleolithic researchers (including Jacob-Friesen, Rust, Weinert, Wetzel, Wiegers, and Zotz) met in 1939 and agreed to continue the system introduced by Mortillet and Breuil (Zotz 1941, p. 180). This quite positive result for the retention of Mortillet's system also manifested itself in the fact that similar units were assigned the same name despite different time allocations. This problem was taken up again in the 1950s. light green (Micoquian as part of the Acheulian), green gradient (Micoquian is Acheulian or Middle Paleolithic), dark green (Micoquian as part of the Middle Paleolithic), blue (Mousterian or Middle Paleolithic), and orange (allocation according to tool types)

\section{Research in the 1950s}

In his presentation of the Paleolithic of Central Europe, Zotz (1951) made reference to his teacher Obermaier and classified the Micoquian as a special form of the Upper Acheulian. The point of reference for his explanations are the artifacts addressed as Micoquian bifaces, though he only describes sites in Central Europe (see Fig. 2).

McBurney (1950), who was familiar with the discussions on Micoquian and Mousterian assemblages, examined the spatial distribution of cordiform bifaces and miniature planoconvex points. He already noticed at this time that a dating of the type site (La Micoque) was not possible. However, he saw great similarity between la Micoque and two southern German sites (Klausennische and Heidenschmiede), assuming that both sites date back to the beginning of the last glacial, which was in line with the approaches of other authors for Bockstein, Vogelherd, etc.

In France, however in the meantime, the definition coined by Breuil was retained for the time being. For example, Blanchard (1948) continued to place the Micoquian (in his capacity as Acheulian VII) in the end of the Riss glacial and the beginning of the last interglacial. Bordes (1954), who assigned numerous assemblages of the Paris Basin to the Upper Acheulian and thus also to the Micoquian, also adhered to this concept. The connection of Upper Acheulian, 
Micoquian, and interglacial, or pre-interglacial assemblages, remained accepted academic opinion until the 1980s (Bordes 1981, 1984).

But Bordes (1954, p. 440) also remarked that the sites he referred to as Micoquian are very difficult to classify if bifaces are not taken into account. For Houppeville, he explained that the assemblage could be assigned to a Moustérien de tradition acheuléenne de facies Levallois (like Moustier G), if these various bifaces, which distinguish the assemblage as Micoquian, did not exist.

In some cases, even sites which do not meet the author's own definition seem to be attributed to the Micoquian. This is clearly visible in a summary of the prehistory of mankind [Urgeschichte der Menschheit] by Grahmann (1952, p. 260), where he writes: "Das Micoque ist immer zusammen mit der Tierwelt des letzten Interglazials vergesellschaftet." [The Micoque is always associated with the fauna of the last interglacial]. On the next page (but in the same paragraph), he deals with Bocksteinschmiede, which, however, was clearly assigned to the period after the last interglacial (Wetzel 1935, 1944).

Müller-Beck $(1956,1957)$ already recognized this discrepancy in the definitions between Western and Central Europe, so that he described the assemblages in southern Germany, previously referred to as Micoquian, as Faustkeilschaberinventare [Hand axe-side scraper assemblages]: "Die Faustkeilschaberinventare Süddeutschlands besitzen mit dem französischen Micoquien einen nur sehr indirekten, lockeren Zusammenhang. [...] Eine etwas nähere Beziehung scheint dagegen zum späten FreilandAcheuleen Nordfrankreichs (Bordes 1954), das auch mit dem anschließenden Micoquien im engeren Sinne nicht direkt gleichgesetzt werden darf, zu bestehen. [...] Das Jungacheuleen Nordfrankreichs ist in die letzte größere Oszillation der vorletzten Kaltzeit zu stellen (Bordes 1954), die Faustkeilschaber dagegen in das beginnende „Postglazial” der gleichen Periode.” (MüllerBeck 1957, p. 124). [The Hand axe-side scraper assemblages of southern Germany have only a very indirect, loose connection to the French Micoquian. [...] In contrast, there seems to be a somewhat closer relationship to the late open-air Acheulian of northern France $[\ldots]$, which cannot be equated with the subsequent Micoquian in the narrower sense. [...] The Upper Acheulian of northern France should be placed in the last major oscillation of the penultimate cold period [...], while the Hand axe-side scrapers should be placed in the beginning "postglacial" of the same period]. The temporal and spatial difference of these industries with the same name had thus been recognized and a separate name was proposed for the eastern half.

From the mid-1950s onwards, Polish and German researchers mostly assume that the assemblages they had agreed upon as Micoquian originate from the Würmian period and should be referred to as Middle Paleolithic. The Western and Central European discrepancy in the allocation of the Micoquian to the Lower or Middle Paleolithic remained largely unchanged from the 1950s to the 1980s (see also Fig. 4).

\section{Research in the 1960s}

From the 1960s onwards, the different use of the term Micoquian manifested itself. In Western Europe, the Micoquian continued to be mostly assigned to the Upper Acheulian, the dominant element remaining the Micoquian biface. In Central Europe, a change in the approach took place, building on the work of earlier researchers (e.g., Wetzel). The Micoquian biface increasingly lost its character as an index fossil, with the Keilmesser (Prondnik, Faustkeilschaber, etc.) taking its place. At this time at the latest, the term Micoquian was used for two units, very probably separated in time and space. The result was that since then, the terms Western and Eastern Micoquian have been used more and more.

\section{Micoquian research from Western Europe in the 1960s}

Let us now first look at the research developments of the 1960s in Western Europe. Burdo (1960), e.g., referred to pieces from La Cotte de-Saint-Brelade in Jersey as micoquoid. In earlier papers, he placed the assemblage in the Mousterian or Acheulian (Burdo 1951, 1956). Due to its great age, this site was later seen as evidence of a long chronology of the Micoquian (Gouédo 1999) or as evidence of the repeated use (or invention) of a very specific technology (tranchet blow) (Frick et al. 2017).

At the beginning of the 1960s, Bordes (1961a) raised the question of whether the MTA (Moustérien de tradition acheuléenne) developed directly from the Acheulian, or whether a Micoquian was interposed, and whether the Micoquian could also occur at the same time as the lower MTA. At the same time, for Bordes, as also for Lumley (1960), it was clear that the Micoquian must belong to the interglacial (Riss-Würm). For Daniel (1965), the Micoquian was also a transitional industry toward the MTA.

Through Bordes (1961b), providing a typological overview of the Lower and Middle Paleolithic, the assignment of artifacts designated as Micoquian bifaces to the Upper Acheulian manifested itself and thus demonstrated the entrenchment of different views of what should now be addressed as Micoquian. This is also reflected in the fact that Bordes (1961a) does not regard the Micoquian as part of his Mousterian complex. Bordes (1966, p. 50) assigned La Micoque to the early last glacial and said that the Acheulian ends far later than previously thought: "There is perhaps place here to say some words about the date of the Micoquian at la Micoque. It has been attributed to the penultimate glacial or to the last interglacial on very flimsy evidences. Modern studies have conclusively shown that it belongs to an early moment of the last glaciation. So the true Acheulean ends much later than was commonly thought. But, outside of la Micoque, there are other Micoquian sites which can be older and this Late Acheulean seems to begin toward the end of the penultimate glacial." 
Numerous other publications from the 1960s, that dealt with finds from Western Europe, agree that atypical bifaces, which can neither be assigned to the classical Acheulian nor to the MTA, are to be added to the Micoquian (e.g., Blanchard 1963; Combier 1965; Joullié 1963; Lumley 1960).

The assemblage of the Verrières-le-Buisson site (excavated between 1958 and 1967), which was later analyzed by Gouédo (1999), was assigned to the Micoquian, but the artifact names manifested the great proximity to the Acheulian, as seen in the following example: bifaces micoquiens de tradition acheuléenne [Micoquian bifaces of Acheulian tradition] (Basse de Ménorval 1966). During the 1970s, the assemblages were increasingly published and assigned to the Micoquian (Daniel et al. 1973; Sacchi et al. 1978). Ulrix-Closset (19691970) was also able to determine that industries containing Micoquian bifaces could easily be addressed as Middle Paleolithic if these pieces were not taken into account. This can be seen as one of the central observations of the 1960s and 1970s. Even Bordes (1984) noted this in his concluding summary of the European material. For French research in the 1960s, the term Micoquian was only of secondary importance: it either represented a subset of the Upper Acheulian or was regarded as a short transition between the Acheulian and the Mousterian. Sometimes, the Micoquian was also seen as a parallel development alongside the Moustérien de tradition acheuléenne (Giot 1962-1963). Thus, the chronological placement of the unit remained inconsistent.

\section{Central European Micoquian research in the 1960s}

At the beginning of the 1960s, Kozłowski summarized the state of Paleolithic research in Poland and assigned the Pradnik group, as defined by Krukowski, to the Mousterian (Kozłowski 1961). Sometimes, the assignment to generic units was simplified by referring to an Acheulian-Micoquian (Acheulo-Micoquian, etc.), like Günther (1962) or Krüger (1964-1965). The former considered the Micoquian as independent and the latter assigned it to the Upper Acheulian.

In the course of the 1960s, assemblages with asymmetrical bifaces, Keilmesser, Faustkeilschaber, Prondniks, etc., were classified in a variety of ways. The term Micoquian was used for assemblages of the Würm glacial (Bosinski 1967; Günther 1964). Bosinski $(1967,1970)$ even made a special reference to the finds from La Micoque N/6. Günther (1964) also sees a clear connection to La Micoque for his finds from Balve, the connecting elements are to him being the Micoquian bifaces. He rejects the name Micoquian, however, for the northern French and Belgian sites, which are supposed to be a Levalloisio-Upper Acheulian and a legacy of the RissAcheulian, which partly reaches into the early Würm (Günther 1964, p. 131). Bosinski (1967), who analyzed the known Middle Paleolithic finds from Western Central Europe, divided the finds, that he assigned to the Micoquian into four groups (Bockstein, Klausennische, Schambach, and Rörshain). He saw the Micoquian as spread from southeast Europe to Western Europe and saw the oldest evidence in southwest France (La Micoque) and the Crimea (Kiik Koba II). Furthermore, he suspected the origin of this industry in the Eem interglacial (1967, p. 83).

According to Bosinski (1967), the most striking feature of the (Central European) Micoquian is the wechselseitiggleichgerichtete Kantenbearbeitung [alternating unidirectional edge regularization, AUER], where an edge is processed unifacially over its entire length before the artifact is turned over so that the same edge can also be processed from the other side.

Another terminological way was chosen by Chmielewski (1969, 1970, 1972, 1975), who kept the La Micoque reference, but included a regional name, where three features outlined the Micoquo-Prondnikian culture he referred to (Chmielewski 1972, p. 174): "1. The production of bifacially retouched tools (handaxes and some scrapers) from flint nodules. Cores with prepared and unprepared striking platforms for flake manufacture, mainly circular in shape, accidental blades. No traces of Levalloisian technique. Large and medium size of the artifacts. 2. Surfacial flat retouche covering whole or most part of the tool surfaces. 3. Side-scrapers prevail over other types of tools. Numerous hand-axes and similar bifacially retouched tools (prondniks) and scrapers. Very few Mousterian points. Few circular scrapers and burins, mainly made of broken tools." He referred to sites from southern Poland (Wylotne Cave, Ciemna Cave, Piekary I and III, Kraków Wawel) and southern Germany (Vogelherd). Using the stratigraphy of Ciemna cave, Chmielewski (1969) divided the Micoquo-Pradnikian into two parts. Ciemna 5 and Buhlen were integrated into the upper unit. The lower unit was formed by numerous assemblages (Wylotne 5, 6, 7/8; Okiennik; Vogelherd; Piekary I and II; Hohle Stein and Ciemna 6). A cladogram of the assemblage cluster term Micoquian for the 1960s is depicted in Fig. 5.

The French Micoquian was regarded by Müller-Beck (1966, p. 1209, note 32) as part of the Micoquoid complexes: "The term "Micoquoid" is used here only to indicate the partial relationship with the Micoquian in Western Europe, which is a late stage of the hand-ax traditions there. In reality the Micoquian of France is itself just one facie; among the Micoquoid complexes." (see Fig. 6).

In his revision of the prehistory of mankind [Urgeschichte der Menschheit], Müller-Beck (Grahmann and Müller-Beck 1967, pp. 232-248) placed the Micoquian in Western Europe in the Upper Lower Paleolithic (Middle Paleolithic) and classified it after the Upper Acheulian. The main distinction he mentions here is that the artifacts of the Upper Acheulian are large and those of the Micoquian rather small. He placed it into the interglacial (the lower Upper Pleistocene by his definition) and shortly thereafter. He further distinguished a West-Micoquian 
Fig. 5 Cladogram of the chronological positioning of the term Micoquian (1964-1969). For the clarification of the Micoquian, mostly attributed to the Middle Paleolithic, the approaches of Günther (1964), Bosinski (1967), Adam (1969), and Chmielewski (1969) are juxtaposed. Notice that Adam does not mention the Micoquian in his structure of the Paleolithic [Großgliederung der Altsteinzeit]. Color code: yellow (Lower Paleolithic, Acheulian), dark green (Micoquian as part of the Middle Paleolithic), and blue (Mousterian or Middle Paleolithic)

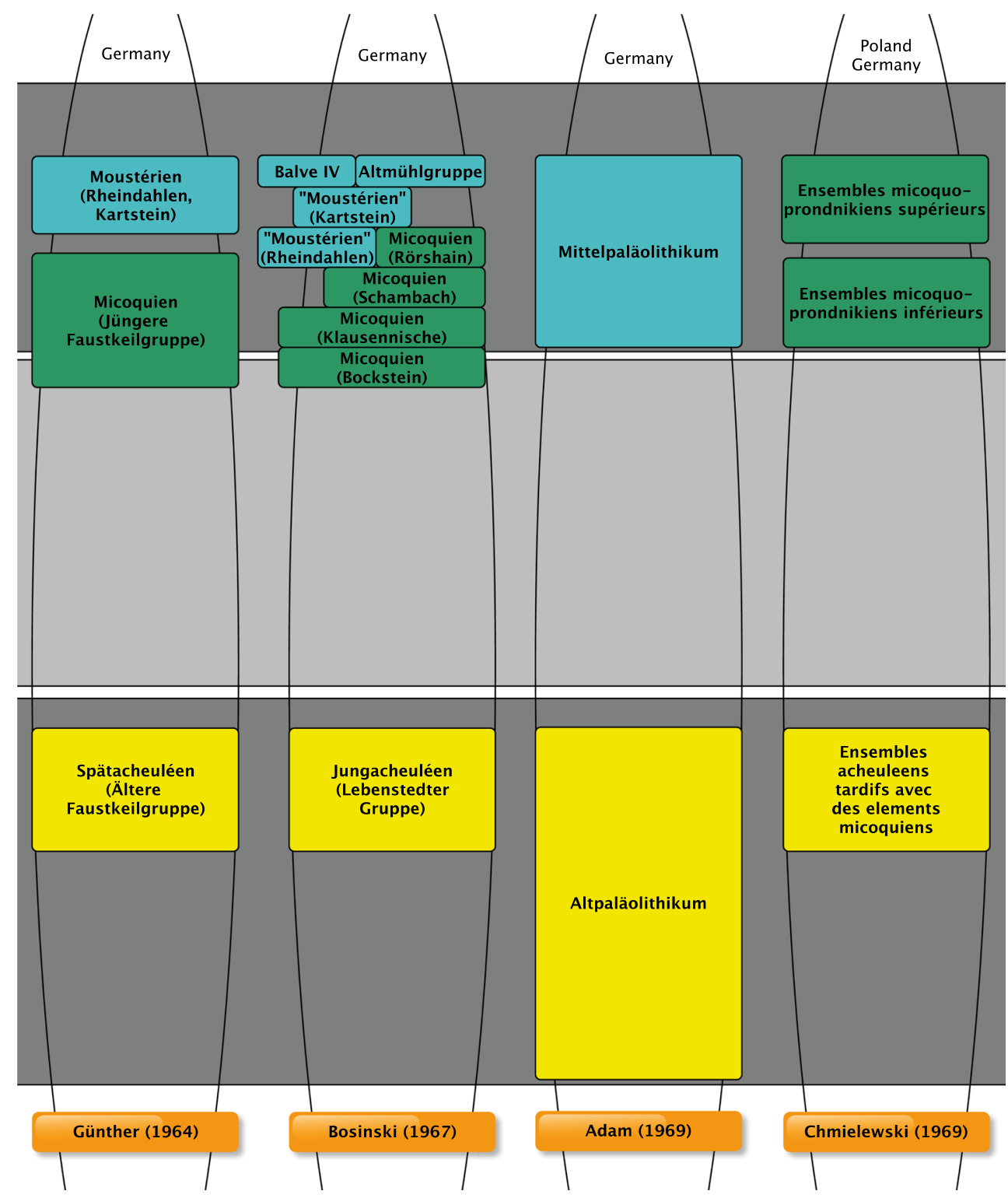

(Western Europe) and East-Micoquian (Central and Eastern Europe). In the discussion of the East-Micoquian, he distinguished an older phase (Bocksteinschmiede, Vogelherd) and a younger phase (Krapina, Kiik Koba, Pantanassa, Okiennik, Ripiceni, Ilskaya, and Starosel'e). The term Micoquian, however, is used by him only for assemblages within Europe.

At the end of the 1960s, Valoch (1967) took a different path for former Czechoslovakia, using the typology established by Bordes and assigning the finds of the Kůlna Cave (layer 7) to the Charentien de tradition micoquienne. Other researchers followed a similar path later. He described how he determined this assignment in the following year by saying (Valoch 1968 , p. 355): “A more significant group, appearing fairly frequently in the western part of Central Europe, is one that corresponds to the biface group of Western Europe. It contains industries distinguished by largely sharp-pointed hand-axes with a thick base, hand-axe-leaves, and small hand-axes, and designated as Micoquian or, in the later phase of their evolution, as Charentien of Micoque tradition. For the period of the last Interglacial, we have as yet insufficient proof of the existence of this Micoque group, yet such industries appear in several localities of South and West Germany in the late Eem, and reach their climax in the early Würm."

The works of the 1960s, mentioned above, all agreed that particular Middle Paleolithic Central European assemblages had to be related to the finds from La Micoque and that they had to be located in the early Würm (see Fig. 5). They all emphasized the similarity of their assemblages to the finds at La Micoque. Chmielewski's approach also combined the proximity of La Micoque with the assemblages published by Krukowski (1939-1948) in which he combined concepts. Already Kozłowski (1924), Benet-Tygel (1944), and 
Fig. 6 Distribution of handaxescraper complexes in Europe. Adopted from Müller-Beck (1966, p. 1196, Fig. 5, modified). In pale blue: distribution of the Western micoquoid complex (Western Micoquian) and in pale red: distribution of the handaxescraper complexes (Eastern Micoquian)

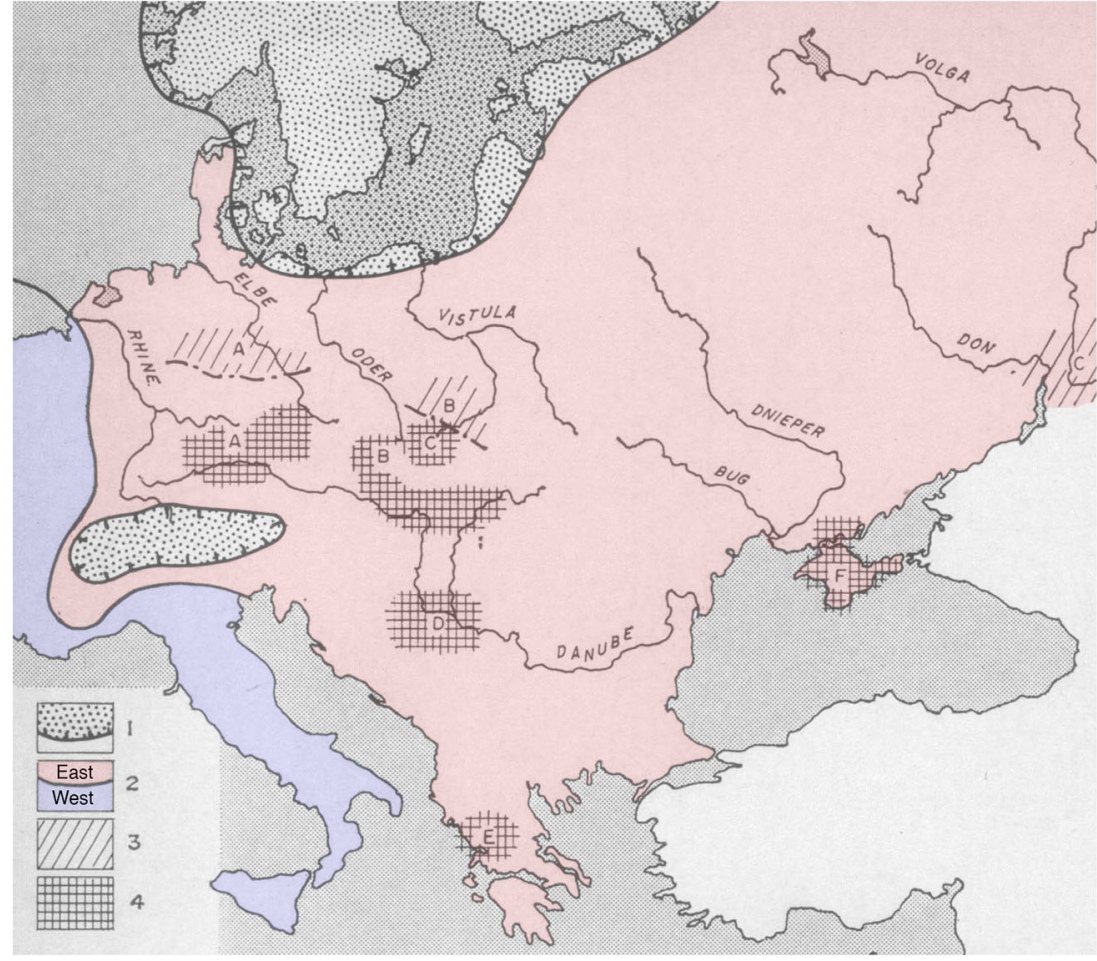

Krukowski (1939-1948) recognized the similarity of Polish finds and la Micoque. It is very likely that the latter used the concept of Breuil to place Polish sites (e.g., Piekary III) into the Upper Acheulian Krukowski (1939-1948, pp. 50-53).

To what extent the temporal shift of the glacial affiliation of sedimentary units (from Riss to Würm), as Gross (19621963) explained, is connected with the increasing location of micoquoid industries in the Würm, remains to be investigated. In this context, not only newly recognized sites of the Würm possessed micoquoid character, but sites that were formerly described as pre-Würm are now to be attributed to the Würm.

At the end of the 1960s, it was possible to intensively investigate further sites by means of improved excavation methodology and typological artifact naming (partly with technological approaches). Buhlen is a good example here (Bosinski 1969; Bosinski and Kulick 1973). An important aspect of this site is the fact that the tranchet blow technology, previously known only from Ciemna in literature (Krukowski 1939-1948), came to light at another site. Initial evaluations in Buhlen made it necessary to extend Bosinksi's model of four assemblage types of the Micoquian by the so-called Pradnik horizon (Bosinski 1969). The Bosinski assemblage types are based on the stratigraphic contexts of the Balve cave, in which the Bockstein type is followed by the Klausennische type. Then, the type Schambach follows and the upper end is represented by the type Rörshein, which is a daring assumption (Bosinski 1967, p. 50). Bosinski now tried to assign the assemblage from Buhlen IIIb to his Micoquian and assumed that it must be younger than the type Bockstein and older than the type Schambach. He saw many parallels to the type Klausennische, but could not make a more exact assignment (Bosinski 1969, p. 73). Sometimes, there were also efforts to date the site La Micoque on the basis of the Central European sites dated to Early Würm and assigned to the Micoquian (Collins 1969), which is, of course, circular reasoning.

To differentiate the French Micoquian of the Seine basin or from La Micoque and the German sites according to Wetzel, Bosinski, or Müller-Beck, Bordes (1968) called the Central European Micoquian: "Micoquien allemande" [German Micoquian]. Bosinski (Wetzel and Bosinski 1969, p. 67) also considered whether it might be necessary to eschew the term Micoquian for one complex or another: „Vielleicht sollte man dieser forschungsgeschichtlich bedingten Zweideutigkeit des Terminus „Micoquien" durch die Wahl einer neuen Bezeichnung entweder für das mittel-und südosteuropäische Micoquien oder für das westeuropäische, zum Jungacheuléen gehörige „Micoquien" aus dem Wege gehen.“ [Perhaps one should avoid this research-historically related ambiguity of the term Micoquian by choosing a new name either for the Central and Southeast European Micoquian or for the Western European "Micoquian" that belongs to the Upper Acheulian]. Thus, by this time at the latest, it is clear that these are probably two complexes that have been given the same name.

\section{The non-European Micoquian in the 1960s}

The term was also in use outside Europe, for example there are descriptions of assemblages from the Levant (e.g., Prausnitz 
1969) or from Anatolia (Esin and Benedict 1963). However, it was occasionally mentioned that the term should only be used for assemblages in Europe. Balout (1967, p. 110) argued that terms coined for industries outside Africa (Clactonian, Micoquian) should not be used in Africa unless their use can be clearly justified. This definition is based on conferences in 1947 (Nairobi, Pan-African Congress on Prehistory), 1955 (Livingstone, Pan-African Congress on Prehistory), and 1965 (Burg Wartenstein Symposium by the Wenner-Gren Foundation) and was published in a very similar way by Clark et al. (1966) a year earlier.

\section{Negation of the term Micoquian in the 1960s}

At the same time, the assignment to the Micoquian was also rescinded. An example is given to illustrate this fact. In the 1930s, Garrod published the finds from Tabun E as Upper Acheulian or Micoquian (Garrod et al. 1937). Now she adopted the nomenclature of Rust and assigned the finds to the Yabrudian (Garrod 1962), as Clark (1966) did, too. The possible link between the Yabrudian and the Micoquian was the subject of lively discussions later on (Ronen and Weinstein-Evron 2000).

\section{Micoquian research in the 1970 s}

\section{Micoquian research from Western Europe in the 1970s}

According to Bosinski (1970), all layers (other than layer I) of the Peyrony excavation at La Micoque belong to the Micoquian (Middle Paleolithic) and layer VI corresponds to the assemblage type Bockstein. According to him, the lower layers possibly represent the initial phase of the Micoquian. This assumption contradicts the analyses of Peyrony (1938) and Breuil (1932b), who assumed that only layer VI could be addressed as Micoquian (as part of the Acheulian). In the same Festschrift volume, Baudet (1970) applied the term Micoquian according to Bordes and Breuil to assemblages from northern France which date to the pre-Würm period.

Increasingly, it can be observed that the typological artifact determination Micoquian biface is becoming more and more detached from the generic unit Micoquian, since the term Micoquian biface can only be interpreted as form-specific and no longer contains a chrono-spatial assignment. In retrospect, this can be seen for sites in the Paris Basin which were deposited during and after the last interglacial and yet all were assigned to a Micoquian due to the presence of pieces referred to as Micoquian biface. It is likely that Brézillon (1971, pp. 160-161) summarized French definitions of Micoquian bifaces from this perspective. On one of these sites in the Paris Basin mentioned earlier, Verrières-le-Buisson, the term Micoquian is used to describe one of the "cultures" that occur.
Fig. 7 Cladogram of the chronological positioning of the term Micoquian (1969 to 1979): a chronological positioning between 1969 and 1976 using the approaches of Bosinski (1969), Schwabedissen (1973), Bosinski and Kulick (1973), Ulrix-Closset (1975), and Lumley (1976); and b chronological positioning between 1976 and 1979 using the approaches of Desbrosse et al. (1976), Gábori (1976), Fiedler (1977), Kozłowski and Kozłowski (1977), and Tuffreau (1979)

In this case, an assemblage of the early Würm is mentioned as Micoquian (Bailloud et al. 1973, p. 105): “[...], l'horizon inférieur a donné une industrie à bifaces appartenant à un Micoquien récent de faciès Levallois du Würm I, le supérieur à un Moustérien tardif du Würm II, également de faciès Levallois." [[...], the lower horizon has yielded a bifacial industry belonging to a recent Micoquian of Levallois facies of Würm I, the superior one belonging to a late Moustérian of Würm II, also of Levallois facies]. The temporal and "cultural" allocation corresponds to Bordes' (1954) approach for sites in the Parisian basin.

The work of Ulrix-Closset (1975) introduced a common element to the Middle Paleolithic in the eastern part of Western Europe (Belgium). She was familiar and worked with the two established classification systems of Bordes and Bosinski and equated her Moustérien à retouche bifaciale with the German Micoquian. At the same time, she used the Mousterian facies developed by Bordes in the 1950s (see Fig. 7a). Further examples of an assignment to the Micoquian come from Eastern France. For Combier and Thévenot (1976), various sites also had at least some affinity to the Micoquian (in particular La Mère Grand in Rully, Saône-et-Loire). However, it is difficult to verify this allocation on the basis of the figure that is intended to demonstrate this (Combier and Thévenot 1976, p. 78, fig. 31). For us, the fragment of a bifacial piece shown there is not enough to make such a precise assignment to a generic unit.

In Western European research, the 1970s was marked by the extensive use of the Bordesian method. This is clearly visible in the very detailed summary of the French research on the Paleolithic, which was compiled for the 9th UISPP Congress 1976 in Niza (Lumley 1976).

In the same year, Desbrosse et al. (1976) published their studies on Prondniks from Germolles. They pointed out the similarity between artifacts from Germolles (Grotte de la Verpillière I) in Saône-et-Loire and those from German and Polish sites, even though, or precisely because, the sites were classified differently. On the one hand, Germolles was attributed to the MTA. On the other hand, the German (Buhlen) and Polish (Ciemna and Okiennik) sites were attributed to the Micoquian. They regarded the "racloirs-couteaux" du type de Prondnik as a common element. For Bosinski (1969), the same artifacts (but named Pradnikmesser) were the common element of his Pradnikhorizont (see Fig. 7a).

In the late 1970s, Bordes (1977, p. 37) raised the question of how the Mousterian should be defined and to what extent 


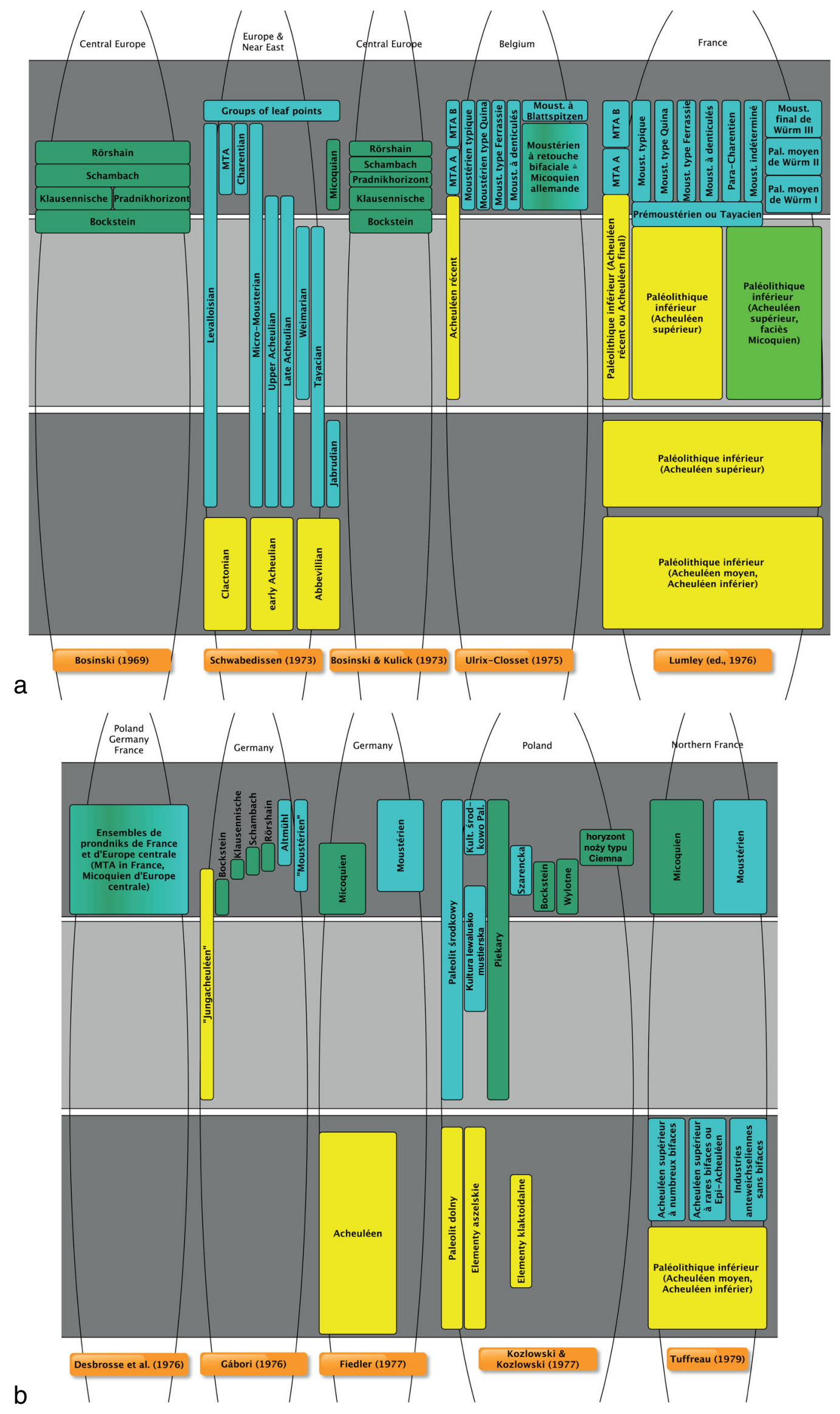


the Micoquian should be integrated into it: "So, one is a little at a loss how to define the Mousterian even in Europe. We can try a chronological approach and say that the Mousterian represents the cultures that flourished during the first half of the last glaciation. But then we would have to include the Micoquian, and to exclude such industries as the interglacial one from Ehringsdorf (East Germany), the Rissian one from Rigabe (Provence, France) or the one from layer 4 at la Micoque, all of which, found outside a stratigraphy, would unhesitatingly have been called Mousterian." This clearly shows that chronological and cultural classifications of assemblages do not necessarily have to coincide.

Through his work in Biache-Saint-Vaast, Tuffreau (1979) was able to show that the beginning of the Middle Paleolithic in northern France probably had to be pushed far back into the penultimate glacial period (see Fig. 7b). His assumption was that alongside the bifacial industries attributed to the Acheulian, there are also unifacial industries (Biache-SaintVaast) that would typologically be addressed as Mousterian (Moustérien typique de faciès levalloisien) in a more recent context. This shifting back of the beginning of the Middle Paleolithic was discussed controversially at the beginning of the 1980s.

\section{Micoquian research from Central Europe in the 1970s}

In Central Europe, the two terms Micoquian and MicoquoPradnikian were mostly used synonymously. Sometimes, artifacts were not described as belonging to the Micoquian, but as possessing a Micoque influence (Boecking 1971, p. 126): "Bei einigen Geräten kann ein gewisser Micoque-einfluß festgestellt werden." [For some tools, a certain Micoque influence can be detected]. Similarly, in southwestern France, Bordes (1971, p. 19) was also able to detect a Micoquian tendency in artifacts from Combe-Grenal: " $[\ldots]$ biface à tendance micoquienne (couche 58)." [Biface with Micoquian tendency (layer 58)]. This Micoquian influence or the Micoquian tendency will still be encountered frequently later on.

Kozłowski already pointed out in 1972 that the term Micoquian may have been poorly chosen for assemblages with Keilmesser with Pradnik form and perhaps also for assemblages with Keilmesser with tranchet blow (Kozłowski 1972, p. 160): "Je ne suis pas favorable à l'introduction du nome "micoquien" pour les ensembles à couteaux-racloirs du type de Pradnik en Europe centrale. Les ensembles du Paléolithique moyen à bifaces d'Europe centrale demandent encore une classification plus détaillée. Il faut introduire pour ces ensembles des dénominations locales." [I am not in favor of the introduction of the name "Micoquian" for assemblages with knife-scrapers of the Pradnik type in Central Europe. The Middle Paleolithic bifacial assemblages of Central Europe still require a more detailed classification. Local denominations must be introduced for these assemblages].
As Central European assemblages have increasingly been reconsidered, the notion of correlation between La Micoque and the Central European sites has given way to the notion that these sites have similar, or to some extent identical, types of finds. Remarkably or particularly noticeably, Bosinski's (1967) observations of the find material increasingly shifted the point of view, with the biface referred to as the Micoquian biface receding into the background in favor of the Keilmesser (with its multitude of names). This have started earlier, when Müller-Beck (1956) adopted the term Faustkeilschaber and promulgated it intensively.

In addition to the assemblages analyzed by Bosinski, further assemblages were added in the course of the 1970s. On the basis of Bosinski's (1967) and Müller-Beck's (1958) nomenclature and explanations of the Micoquian, Mania and Toepfer (1973) integrated the assemblages from Königsaue A and C into the Micoquian as defined by Günther (1964) and Bosinski (1967). Mania and Toepfer (1973, pp. 144-145) also found a connection between Mousterian and early glacial biface cultures, which they initially call Micoquian: "Nach der vergleichenden Betrachtung der frühglazailen [sic!] BifaceKulturen des europäischen Moustériens, die vorerst als Micoquien bezeichnet wurden, lassen sich einige allgemeine Überlegungen anstellen." [On the basis of a comparative examination of the early glacial Biface cultures of the European Mousterian, which were initially called Micoquian, some general considerations can be made]. Building on a previous work, the Micoquian also represented a pan-European generic unit for Mania and Toepfer (1973). As can also be seen on other maps (see Fig. 2), the Micoquian seems to be predominantly represented in Central Europe. To the west and completely remote La Micoque can be found, but east of the main distribution there are also isolated sites (see Fig. 8).

After completion of the excavations in the late 1960s, a preliminary report on the Buhlen site was presented (Bosinski and Kulick 1973). It was suggested to place the assemblage IIIb (Buhlener Pradnikhorizont) chronologically somewhere between type Klausennische and type Schambau (see also Fig. 7a). For the Weinberghöhlen (layer $5\left(F^{\prime}, G^{\prime}, G\right.$, $\mathrm{H})$ near Mauern, Müller-Beck spoke of a mousteroid late Micoquian followed by an assemblage of the "Altmühl group" (Koenigswald and Müller-Beck 1975) or a Central European Late Micoquian (Koenigswald et al. 1974), but he had to admit that the available assemblage was too small to make reliable statements. After viewing the drawings, it seems as though the levalloid character of the unifacial pieces was noticed and set aside as an antithesis to the asymmetrical bifacial component. This type of synthesis of unifacial and bifacial assemblage components will be encountered again in later times.

Gábori (1976) was extensively occupied with the assemblages of the Micoquian in the region between the Alps and the Urals. He correlated the temporal position of assemblages 


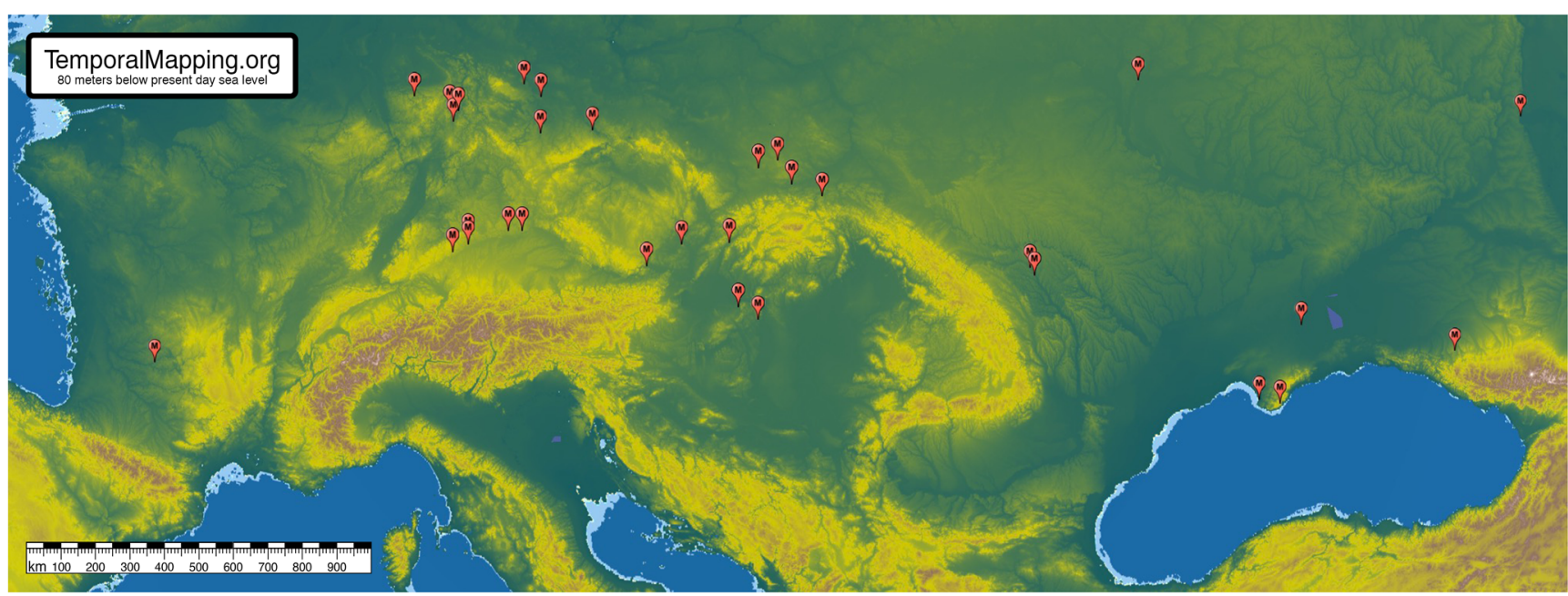

Fig. 8 Distribution of the Micoquian according to Mania and Toepfer (1973, Abb. 37). Base map from TemporalMapping.org ( $80 \mathrm{~m}$ below present-day sea level)

with the inventory types defined by Bosinski and derived a refined chronological assignment of the inventory types (see Fig. 7b).

The assumption that the Levallois concept within the assemblages described as Micoquian was of very subordinate importance or even completely unknown manifested itself visibly. For Fiedler (1977), this was impressively demonstrated in Buhlen IIIb: "Die meisten Werkzeuge sind in „Kerntechnik” durch beidflächige Retuschierung hergestellt, während Abschlagwerkzeuge selten sind und die Levalloistechnik praktisch keine Rolle spielt." [Most tools are manufactured in "core technology" by double-surface retouching, while blank tools are rare and the Levallois technique plays practically no role]. It was only in the 1990s that it was recognized that in some sites there was a connection between Keilmesser (of any shape) and the Levallois concept (e.g., Richter 1997).

\section{Discussion of a long or short chronology for the Micoquian}

Since the 1970s, there has been an enormous increase in the knowledge of relative and absolute chronological dating. These new and more precise methods were used to reevaluate the generic units that had previously been considered fixed in time. Through more precise evaluations of the chronological position of recognized phenomena, the chronological approaches varied in length. Furthermore, the system established by Bosinski (1967) was used to structure the Middle Paleolithic assemblages of western Central Europe and was even extended to eastern Central Europe and Eastern Europe (Gábori 1976). This short chronology for the Micoquian stood in contrast to the long chronology for Polish sites proposed by Kozłowski and Kozłowski (1977) which spread from the early Würm to the last interglacial period.
They also distinguished seven types of assemblages and separated assemblages with asymmetric knives and foliated pieces (see Fig. 7b). The term Group of backed Bifaces was used by Schild and Wendorf (1977) only to group bifacial objects of the Central European Middle Paleolithic and not to classify assemblages as a whole (in our understanding).

At this point, at the latest, it is obvious that different chronological systems are applied in the association of assemblages with the term Micoquian. If the Upper Acheulian (Jungacheuléen) is included in the analysis, the chronological framework becomes even more complex (depending on whether the Micoquian is added to the Upper Acheulian or the Middle Paleolithic).

The question also arose as to whether the Micoquian might not also be part of the Moustérien. Ulrix-Closset (1975, pp. 11-12), for example, coined the term "Moustérien à retouche bifaciale" because she could not find a suitable name in French terminology. She did not want to use the term "Moustérien à Blattspitzen" because it did not describe the Central European assemblages (up to $50 \%$ bifaces, Keilmesser and Blattspitzen) precisely enough, and the term Blattspitze was described very precisely in German literature. For her, the term "Moustérien à Blattspitzen" is synonymous with "Altmühlgruppe" as defined by Bohmers $(1944,1951)$ and should not be used as an umbrella term. In her understanding, the term "Micoquien," as it was used by various German authors, can no longer be used, since it has already been assigned a very precise meaning (in chronological and typological terms) in French literature. Thus, she attests the same meaning to the different terms "mitteleuropäisches Micoquien" (sensu Bosinski) and Eastern Micoquian (sensu Müller-Beck) and believes that these correspond best with a "Charentien de tradition micoquienne" (sensu Valoch). Her "Moustérien à retouche bifaciale" is characterized by a high percentage of bifaces, bifaces scrapers (or bifacially backed 
pieces), and foliated pieces. For her, the term emphasizes that it is indeed a Mousterian industry with points and scrapers, but it is clearly characterized because of the use of a particular retouch technique.

The example shows that the former division into a western and eastern Micoquian, which are represented in different time stages, is no longer applicable. Thus, the controversy remains as to what or which assemblages should now be subsumed under the term Micoquian.

\section{Research during the 1980s}

The 1980s brought momentum to the Micoquian discussion in that the beginning of the Middle Paleolithic was massively postponed and now falls into the period of the Saalian/Riss glacial (Bosinski 1982; Tuffreau 1982). This shift of the transition from the Lower to the Middle Paleolithic was also reflected in the assignment of the Micoquian. Three approaches to the classification of the Micoquian and the beginning of the Middle Paleolithic are shown in Fig. 9, each of which is plausible for its region.

From this time on, the Micoquian in Western Europe is also increasingly classified as belonging to the Middle Paleolithic, but still with the difficulty that the upper layers of the eponymous site have no dating and were destroyed by former excavations (Rigaud 1986). The spectacular assemblages from $\mathrm{La}$ Cotte-de-Saint-Brelade (Callow and Cornford 1986), BiacheSaint-Vaast (Tuffreau and Sommé 1988), or Mesvin IV (Cahen et al. 1984; Cahen and Michel 1986), which probably date from the Saalian glacial, were able to show at that time that elaborated finds could be much older than previously thought. It is noteworthy in this context that two of the sites have evidence for the presence of Keilmesser with tranchet blow (Pradniks, see Soriano 2000, 2001), a technology that was repeatedly attributed to the so-called Pradnikhorizont in the following decade (e.g., Jöris 1992).

\section{0s research on the Micoquian from Central Europe}

The existing diversity of names in relation to assemblages that (predominantly) have great similarities in their bifacial components was discussed by Bosinski (1981). He agreed that the assemblages referred to by Chmielewski (1969) as MicoquoPradnikien, those referred to by Ulrix-Closset (1975) as Moustérien à retouche bifaciale and referred to by himself as Micoquien, could possibly, on the basis of Kolosov (1986), be referred to with the term Bockstein culture (see also Bosinski 1985, p. 62). Kolosov adopted this term probably from Wetzel (but referred to Wetzel and Bosinski 1969), who used it as synonym for his Micoquian at the Bockstein site (Wetzel 1954). Obviously, this was a rather impractical suggestion, since Bosinski himself used the term Bockstein as an assemblage type within his Micoquian and thus represents a pars pro toto. Only one further use of the term as a synonym for the Micoquian in the literature could be discovered (Freericks 1995).

The "antipodes" Micoquian and Mousterian were increasingly established and so Feustel (1983, p. 12) wrote in this context: "Trotz der nun großen Vielzahl und mehr oder weniger klar zu unterscheidender Typen ist über weite Räume hin eine gewisse Gleichförmigkeit zu beobachten; Bezeichnungen wie Moustérien und Micoquien bringen bei aller Differenziertheit im Einzelnen doch große Zusammenhänge zum Ausdruck." [In spite of the now large number and more or less clearly distinguishable types, a certain uniformity can be observed over wide spaces; designations such as Mousterian and Micoquian express broad interconnections despite all the differentiation in the details].

Ringer (1983, pp. 68-69) adopted the technological distinction introduced by Bosinski (1967) between the edge retouching of the German and French Micoquian for bifaces and his new defined Babonyian. Here, we want to illustrate these three technological production approaches on bifaces (see Fig. 10). The produced bifaces differ not only in the order in which the surfaces or edges are processed, but also in the different cross-sections created.

In many sites, even in the 1980 s, it can be seen that a shift in the value of bifacial pieces has taken place. While in earlier works the focus was on the presence of the so-called Micoquian bifaces, this increasingly shifted to the presence of asymmetric bifacial pieces that could not be described adequately with the Bordesian typology. A dichotomy was thus revealed, which was met by using the Micoquian biface as a representative of a Micoquian according to Bordes, whereas asymmetrical bifacial pieces (Keilmesser) were associated with the Central European Micoquian. This dichotomy was already detected in the 1950s by Müller-Beck. He emphasized the differences between the central French assemblages and the southern German assemblages (Bordes and Müller-Beck 1956; Müller-Beck 1956, 1957).

The presence of Keilmesser has been used as a decisive criterion for assemblage classification into the Central European Micoquian since, at the latest, Bosinski (1967). This is evident, for example, for the Micoquian layers of the Kůlna cave. Valoch $(1988$, p. 55) writes that bifaces and Keilmesser are of decisive importance for the classification, although their share in the type spectrum is rather small. Twenty years earlier, he used the term Charentien de tradition micoquienne [Charentian with Micoque tradition] to express the scraper component (Valoch 1967). In the meantime, different terms were used as synonyms for the Central European assemblages, often side by side, since both terms are roughly to bundle the same assemblages within one term. Thus, increasingly similar sentences as the following one can be found in many publications since the 1980s (Kozłowski 1989, p. 
Fig. 9 Cladogram of the Lower and Middle Paleolithic transition. Here, the approaches of Bosinski (1982), Laville (1982), and

Tuffreau (1982) are juxtaposed
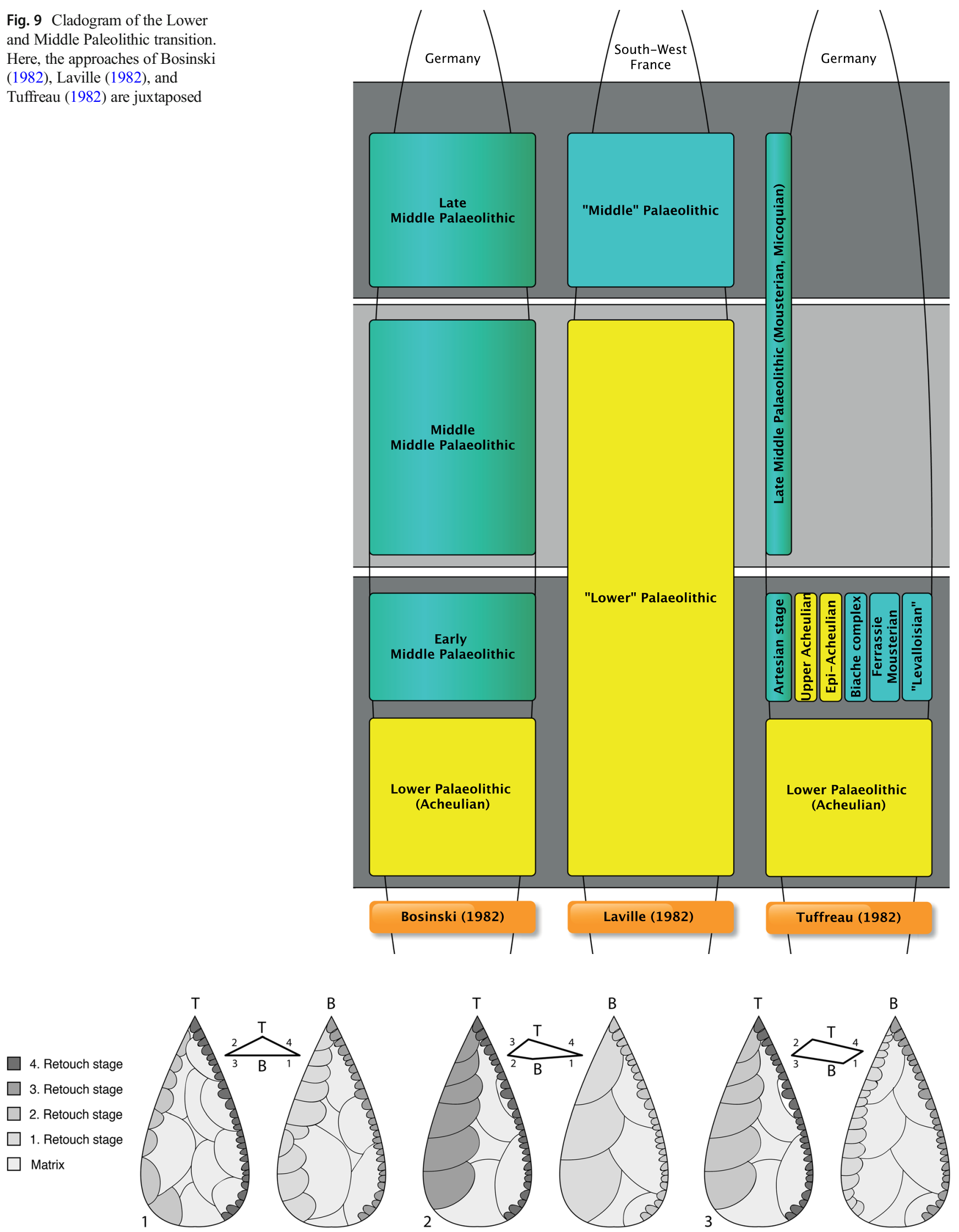

Fig. 10 Technological approach on edge retouch. (1) German Micoquian (Bosinski 1967) and (2) French Micoquian and (3) Babonyian (Ringer 1983), added by retouch stage succession 
139): "Les autres sites attribués à la ,,culture micoquoprondnicienne" ou au, Micoquien de l'Europe centrale“, n'ont que des analogies plus générales avec l'industrie de la grotte Ciemna." [The other sites attributed to the "MicoquoProndnician culture" or the "Micoquian of Central Europe", only have broader analogies with the Ciemna cave industry].

\section{0s research on the Micoquian from Western Europe}

In contrast to Central European researchers, Bordes (1981, 1984) maintained the connection between the Micoquian and the Upper Acheulian for the West European assemblages (see also Fig. 11a). However, he was aware that the Micoquian differed from La Micoque (and thus certainly also from the sites he worked on in the Seine basin) and the German Micoquian. He also drew attention to the differences in relation to tools from blanks (Bordes 1981, p. 78): "Les relations du Micoquien de la Micoque et du Micoquien allemand sont également peu claires: s'il y a de grandes similitudes en ce qui concerne les bifaces, l'outillage sur éclats du gisement allemand est pauvre et peu nombreux, à l'inverse de ce qui se rencontre à la Micoque." [The relationship between the Micoquian of la Micoque and the German Micoquian is unclear: while there are great similarities in terms of bifacial tools, the German sites' flake tools are poor and few in number, unlike those found in la Micoque]. Bordes' approach is complemented by the approaches of Tuffreau (1988) and Campy et al. (1989). However, the latter two contradict each other. Tuffreau (1988) argued that the French Micoquian should be placed in the same time span as an early Mousterian: before the last interglacial (Fig. 11b). This stands in contrast to Campy et al. (1989), who continue to regard the Micoquian as an interglacial phenomenon (Fig. 11c).

The combination of micoquoid-looking artifacts and dating into the early Würm was described repeatedly in the course of the 1980s. Examples come from the extreme East of France (Guillaume 1982; Janot 1981), from Jura Dept. (Campy et al. 1989) or from Aube Dept. (Boëda and Mazière 1989). However, the opposite combination, the connection between micoquoid artifacts and a pre-Würm dating, can be found as well. Here, we refer to works from Central France (Despriée and Lorain 1982) or southwestern France (Leclercq and Briois 1982). In the Dordogne for itself, only layer 6 of La Micoque was considered to be the actual Micoquian (see Rigaud 1988, p. 437) as Breuil did in the 1930s.

Focusing on the northwest of France, we can see that there were different described sites (Treissény, Bois-du-Rocher, or Kervouster) that supposedly had a certain similarity to the Central European Micoquian or Jungacheuléen (Monnier 1988, p. 77).

Due to the presence of pieces with tranchet blow (lateral tranchets or LSF removals), the Mesvin IV and La-Cotte-de-
Saint-Brelade sites were compared to the Central European Micoquian most often attributed to the last glacial (Cahen and Haesaerts 1984; Cahen et al. 1984; Cahen and Michel 1986; Callow and Cornford 1986). Thus, it was recognized that technologies that are very similar or even identical to each other can sometimes occur in clearly separated periods of time. This can be seen as a further indication that while it may be appropriate to compare such phenomena technologically, it is not sensible to combine them in the same generic unit.

\section{Micoquian research in the 1990s}

\section{The 1990s in Central Europe: new approaches bring forth new concepts and terms}

Another prominent point in the history of Micoquian research is the attempt to give a new name to Keilmesser-bearing assemblages in Central Europe. At this point, at the latest, the Micoquian biface loses its significance as a name-giving assemblage element and is replaced by the Keilmesser (as reported, Müller-Beck used the term Faustkeilschaber for his generic unit), which was already regarded as definitive for complexes in the 1950s (Müller-Beck 1956, 1957).

To structure the material of the Bilzingsleben site, Mania (1990) distinguished two groups of assemblages for the late Middle Paleolithic and used two characteristic bifacial object groups (Keilmesser and Blattspitzen) as the distinguishing feature. For the first groups, he used three descriptive terms: Inventare mit Keilmessern [assemblages with Keilmesser], Keilmesserinventare [Keilmesser assemblages], and Keilmessergruppen [Keilmesser groups]. He described these groups as belonging to the Micoquian (Mania 1990, p. 146): "Diese Inventare werden im allgemeinen dem Micoque-Kreis (Fundstelle La Micoque vom Vezere-Tal) zugeschrieben und sind durch asymmetrische, schlanke Faustkeilmesser mit seitlichem Rücken charakterisiert." [These assemblages are generally attributed to the Micoque circle (La Micoque site of the Vezere Valley) and are characterized by asymmetrical, slender biface-knives with lateral backs]. Mania (1990, pp. 146-148) does not limit his description to this assignment, but also describes the lithic typo-technology of these assemblages: long narrow biface leaves (Faustkeilblätter) produced in the same technique, Levallois technique predominates, numerous discoid cores, differently shaped scrapers (single, double, angled, convex, curved, straight, and transverse scrapers), and numerous blades. The presence or absence of the Levallois concept will be discussed repeatedly in later works. In addition to the discussion of the lithic assemblages, Mania (1990, p. 148) narrows the groups down to the early Würm (see Fig. 12) and describes their distribution over the whole of Western, Central, and Eastern Europe. The main area of the 
Fig. 11 a-c Cladogram of the Micoquian positioning in Western Europe (1984-1989), according to Bordes (1984), Tuffreau (1988), and Campy et al. (1989)

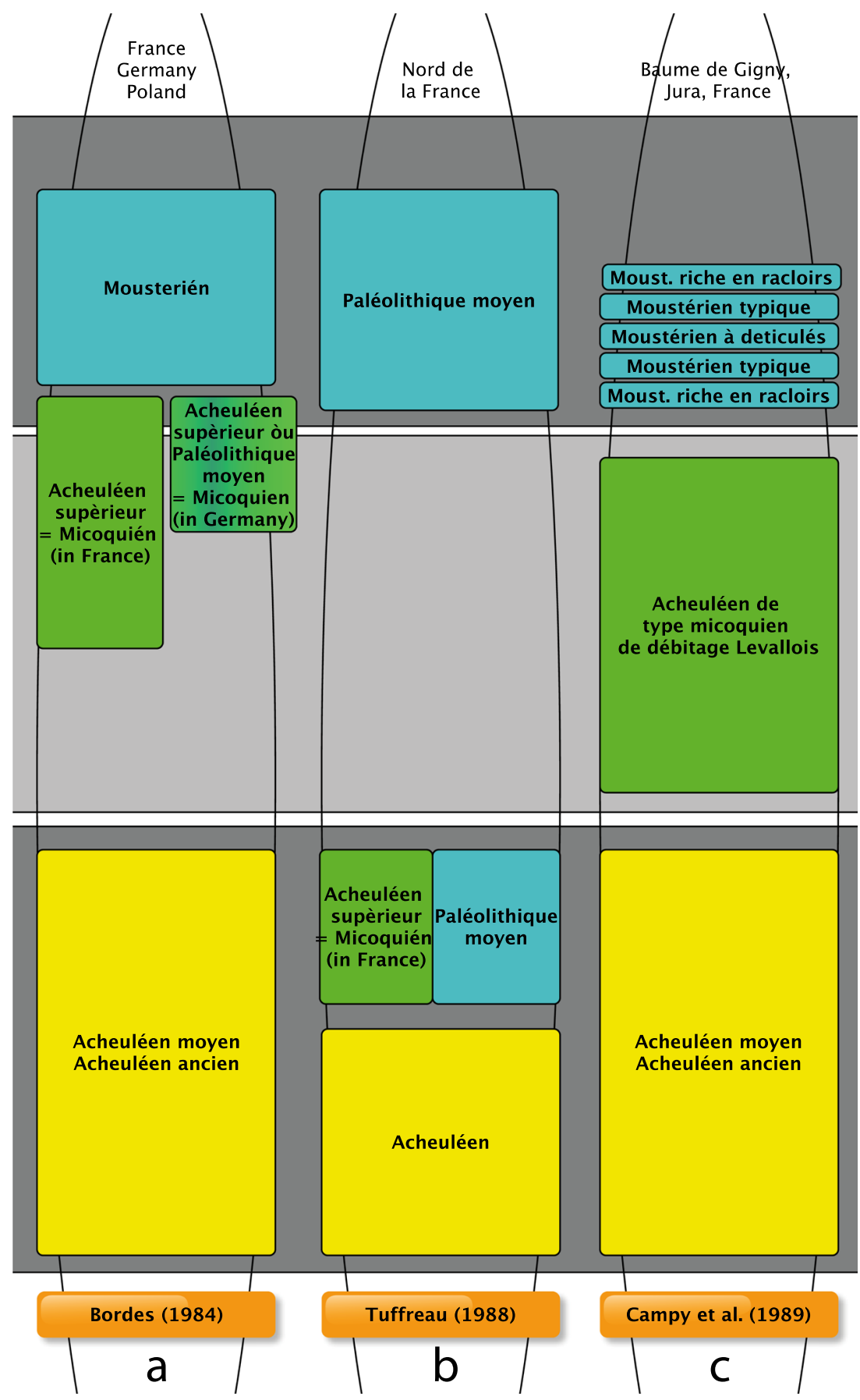

Mousterien, however, was in the west, whereas the main area of the Keilmesser groups was in the east. This description barely differs from other descriptions of the previous two decades, and only the term Micoquian was replaced by the term Keilmessergruppen. For groups that were chronologically later, he adopted the term Blattspitzengruppen from the literature, a term that has already been used by various researchers for some time (e.g., Freund 1963; Kozłowski 1961; MüllerBeck 1956; Schönweiß 1962-1963; Valoch 1955; Zotz 1951).
In the following years, the term Keilmessergrupppen was adopted by various authors, most of them German-speaking, and mostly used as a synonym for the assemblages previously defined as central European Micoquian. The point of reference for this renaming was essentially that even more recent investigations in La Micoque were not able to work out a clear chronological classification of the upper layers. Veil et al. (1994, pp. 40-41) give some reasons why the term Micoquian should be replaced: 


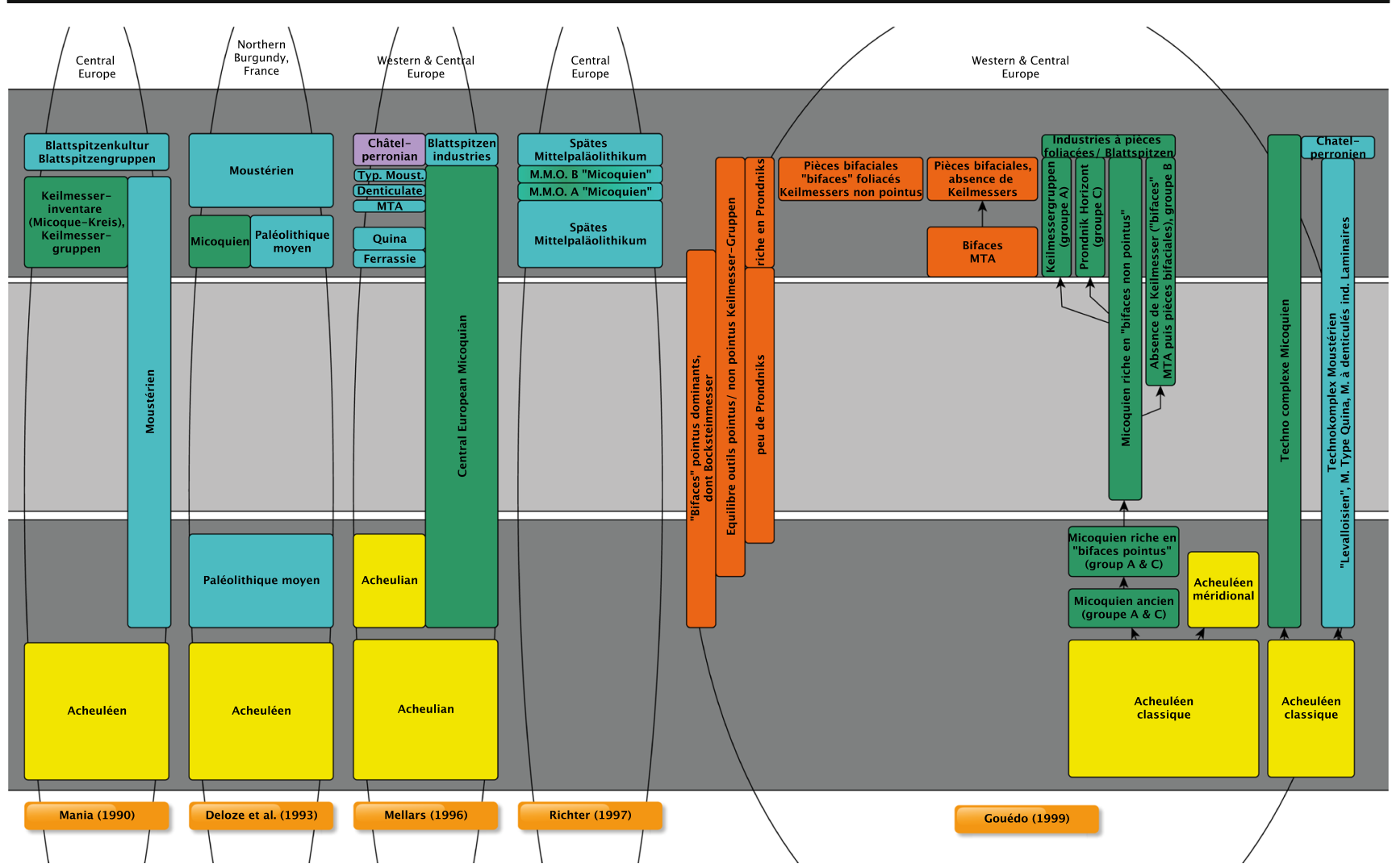

Fig. 12 Cladogram of Micoquian positioning in Western and Central Europe (1990-1999), according to Mania (1990), Deloze et al. (1994), Mellars (1996), Richter (1997), and Gouédo (1999)

- The type assemblage of the layer N/6 (Peyrony excavation) of La Micoque is not considered typical or representative of all the assemblages covered by the term Micoquian.

- The characteristic element in La Micoque, the Micoquian biface, is not or only very rarely present in Central European sites (Lichtenberg and Königsaue are mentioned here).

- Although the tool spectrum of the assemblage N/6 is considered representative of Bosinski's Bockstein type, it has very little in common with the entirety of the sites in Central and Western Europe, apart from a special processing technique [this probably refers to the alternating unidirectional edge regularization, AUER].

- Uncertain time setting of the type assemblage.

- Uncertain in situ character.

- Ambiguity due to the research history of the term Micoquian.

On the basis of these arguments, Veil et al. (1994, p. 41) propose using the term Keilmessergruppen (Micoquian sensu Bosinski, Günther, Toepfer, Valoch) as it designates the smallest common denominator of the comprehensive Weichselian bifacial assemblages of Central and Eastern Europe, and assemblages of these groups are apparently generally characterized by very standardized bifacial cutting tools, which are formally known as leaf-shaped scrapers, foliated bifaces, etc. In this context, it has to be borne in mind that Keilmesser appearing in the assemblage are not to be understood as conditio sine qua non for belonging to these groups. Another important statement is to be reproduced here literally: "Selbstverständlich soll die vorgeschlagene Zusammenfassung der Inventare unter diesem deskriptiven Namen zunächst keine Aussage über ihre Beziehungen untereinander beinhalten, seien sie nun ethnischer, funktional, aktivitätsspezifischer oder chronologisch-genetischer Art." [Therefore, Keilmesser appearing in the assemblage are not to be understood as conditio sine qua non for belonging to these groups [...]. Of course, the proposed consolidation of the inventories under this descriptive name should not initially contain any statement about their interrelationships, be they ethnic, functional, activity-specific or chronological-genetic.]. The preceding explanations led Jöris (1993, p. 46) to regard the terms Micoquian and Keilmessergruppen being synonymous: "Micoquien [= Keilmessergruppen (VERF.)]."

Bosinski (1967) already suspected a decrease of the bifacial assemblage component within his Micoquian. Kind (1992) adopted this assumption and attempted to divide the Middle Paleolithic assemblages in southern Germany into groups on the basis of data from the literature. In addition to a tripartite division already established by Bosinski (Micoquian, Mousterian, Leaf point group), he was able to identify another 
mixed group which has strong similarities to the Mousterien group. A limiting factor in this study, which is also mentioned therein, is that typological evaluations from earlier years had to be used. In the 1990s, Bosinski also began to understand the terms Micoquian and Keilmessergruppen as synonymous (Bosinski et al. 1995, p. 848). Numerous researchers also began to favor the term Keilmessergruppen over the term Micoquian (e.g., Street et al. 1999).

Parallel to the establishment of the new term Keilmessergruppen, the term Micoquo-Pradnikian used by Chmielewski (1969, 1970, 1972) continued to be used and Bárta (1990) thus used the term Micoquien-Pradnik-Kultur. Sometimes, it seems that the differences between Mousterian and Micoquian in western Central Europe have been emphasized more than in the eastern part, e.g., Bárta (1990, p. 125) discusses the possible existence of the Micoquien facies of the Mousterian.

Another approach was advocated by Richter (1997). In the analyses of the assemblages of the G-layer complex of the Sesselfelsgrotte, he found that sometimes the assemblages alternate between many and few or no bifacial elements. His conclusion was that these were initial and consecutive (subsequent) assemblages with a high raw material diversity in the early stages (initial) and only a few or no bifacial elements at all. In the late stage (consecutive), the raw material diversity decreases, but the bifacial component increases. If the unifacial component is considered to be Mousterian and the bifacial component represents Micoquian, these assemblages can be considered to be Mousterian with Micoquian option, whereby the Micoquian option increases over the duration of the settlement. In this approach, Mousterian and Micoquian are no longer perceived as separate entities. In a further evaluation of the assemblages, that had previously been classified as Micoquian (or Keilmessergruppen), he divided the M.M.O. into an early (M.M.O.-A) and a late phase (M.M.O.-B). These two phases differ not only in their chronological position (see Fig. 12), but also in their production of the unifacial accompanying industry. The older Micoquian (M.M.O.-A) is a (mainly) non-Levallois industry, whereas the younger one (M.M.O.-B) is characterized by Levallois.

\section{Micoquian research in Western Europe during the 1990s}

In contrast to research in Central Europe, where new terms were established for the Micoquian, the term Micoquian continued to be used intensively in Western Europe.

In the course of technological considerations, Boëda (1991a) described characteristic differences between MTA bifaces and Micoquian bifaces and thus showed a further way to delineate differences between morphologically similar objects by means of technological criteria. Although both pieces are retouched at the edge in such a way that they become plano- convex and are only retouched at the convex edge, the shape of the surfaces is very different. Both surfaces of Micoquian bifaces are plano-convex. On the other hand, the surfaces of the MTA bifaces are generally convex and only the edges are plano-convex. There are also differences in symmetry. Micoquian bifaces show a double asymmetry, which can be seen in cross- and longitudinal section. In the MTA bifaces, however, the cross-section is only slightly asymmetrical. However, both can be symmetrical when viewed from the top.

During the 1990s, the question of which assemblages can or should be addressed as Micoquian was raised again. In addition to the sites in Brittany (Cliquet and Monnier 1993; Monnier 1986), systematic research in eastern France also contributed to the discussion. In this context, sites investigated by Farizy (formerly Girard) in the 1980s and early 1990s played a role. Of importance here is the site Champlost (Yonne), which was attributed to a "charentoïdo-micoquien" facies (Deloze et al. 1994, p. 20) by its asymmetrical bifacial component and a systematic Levallois reduction. Thus, the reference was assigned to the Mousterian system, but the deviating bifacial component was taken into account. Of interest at this site is not only the combination of Levallois and asymmetrical bifacial components but also the known tentative TL dating between 65 and $45 \mathrm{ka}$ (Farizy 1995). According to Farizy (1995), the Grotte de la Verpillière I (Desbrosse et al. 1976; Desbrosse and Texier 1973b), Blanzy (Desbrosse and Tavoso 1970), or Bissy-sur-Fley (Desbrosse and Texier 1973a) in southern Burgundy also belongs to these sites and is part of her Industries charentiennes à influences micoquiennes. Also, in the course of motorway constructions in the early 1990s, numerous open-air sites were excavated in northern Burgundy. In two sites (Les Hauts Massous in Vinneuf and La Prieurée in Villeneuve-l'Archevêque), the bifacial component was used to assign find layers of the early Würm to the Micoquian (Deloze et al. 1994). In contrast to earlier French works, these assemblages described as Micoquian were clearly assigned to the Middle Paleolithic and sometimes seen as western extensions of the Micoquian sensu Bosinski (1967).

Understandable as it may be to place these assemblages alongside the Central European Micoquian, the question now arises to what extent assemblages before the Eem, during the Eem, and after the Eem might be interrelated. This is one of the questions to which Gouédo (1999) devoted himself. Gouédo (1999, pp. 7-16) is intensively concerned with the research history of the generic unit Micoquian and identifies the definitional differences between the typological approaches of Bordes (1954) and Bosinski (1967). However, both typological approaches are based on the presence of "Micoquian bifaces." The decisive difference between the two approaches is what is meant by this. For French research, the Micoquian biface plays the central role, as there are hardly any other types. Outside of France, however, the focus is on the Keilmesser family. The further we move east, the rarer the Micoquian biface becomes. These are essential factors that attracted the attention of 
researchers as early as the 1950s. The unifacial reduction systems used at the same time are also of great relevance. In addition to typological criteria, technological criteria also play a role in bifacial pieces. Here, Gouédo (1999, pp. 15-16) refers to the morphology of the pieces and points to plano-convex cross-sections and trifacial concepts of the tools, regardless of whether they occur in France or east of the Rhine, or whether the accompanying industry is based on Levallois or not. He then distinguishes the views of typologists and technologists on the research object Micoquian: "La vision technologiste tend donc à unifier le monde micoquien tout en montrant des différences entre groupes alors que la vision typologiste bordienne tend à accentuer ces différences." [The technologist vision therefore tends to unify the Micoquian world while showing differences between groups, while the Bordian typologist's vision tends to accentuate these differences]. Overall, he concludes that the Micoquian phenomenon is by far not considered homogeneous. Gouédo's evolutionary approach to the course of the Micoquian involves a threefold division in time (Micoquien ancien, Micoquien riche en "bifacees pointus," and Micoquien riche en "bifaces nonpointus") and in its structure (groups A, B, and C). Group A is based on the assemblages in Vinneuf and Verrières. Group B is represented by the MTA-A and group $\mathrm{C}$ is based on the assemblage of Champlost (see Fig. 12). According to him, the Micoquian originates from the classical Acheulian as in the sites in Cagny around 450 to $400 \mathrm{ka}$. The Micoquien ancien and then the Micoquien riche en "bifacees pointus" contain two development groups that are not entirely separate (groups A and C); only later in the Micoquien riche en "bifaces non-pointus" do the development lines separate. On the one hand, there is a branch that is characterized by Keilmesser (Keilmessergruppen, group A) and one that is called Pradnikhorizont (group C). On the other hand, there is a branch in which only very few Keilmesser occur, but other types of bifacial pieces (Gouédo 1999, fig. 176). This approach attempts to draw a clear line of development for sites from Western and Central Europe that have so far been referred to as Micoquian. The Micoquian, parallel to the Mousterian, is regarded as an independent development. However, it should be noted that the context presented contains only the technical development and the Micoquian is regarded as a technocomplex (as understood by Clarke), within which the same or very similar concepts of tool manufacture are applied.

\section{Micoquian research in the 2000s}

\section{Micoquian research in Central Europe during the 2000s}

In the early $2000 \mathrm{~s}$, the amount of data that can be evaluated in relation to the literature available increased enormously, so that a strict selection had to be made. The reason for this is twofold. One is the increasing amount of written literature; the other is the amount of scanned or online publications that can be searched successively for keywords. Therefore, hopefully, an adequate selection of representative contributions has been made to do justice to the matter.

At the beginning of the 2000s, Conard and Fischer (2000) attempted to summarize and present the current state of research on the Middle Paleolithic in relation to cultural units. In contrast to Bosinski (1982), who favored a tripartition, they assume a dichotomy into Early Middle Paleolithic (Saalian/ Rissian assemblages) and Late Middle Paleolithic (Eemian and Weichselian/Würmian assemblages). The term Keilmessergruppen is preferred to the term Micoquian. They also propose using the terms Keilmessergruppen and Pradnik Group as synonyms. Furthermore, the authors suggest that the term para-burin, which was introduced into research in the 1960s by Polish researchers (Chmielewski 1969; Kowalski 1967), be preferred to the term Pradnik technique in order to emphasize it. They also assume that although the separation of Keilmesser assemblages and Mousterian assemblages can sometimes be imprecise, reduction systems alone cannot be used for the separation (Conard and Fischer 2000, p. 12): "While it is clear that the distinctions between Late Mousterian and Keilmesser assemblages are not always sharp, it seems unlikely that the observed variation can be explained solely on the basis of reduction sequences." Nevertheless, the Mousterian in particular remains a reservoir for assemblages made by blank tools with or without the use of the Levallois concept. Furthermore, they note that their approach assumes that similar assemblages do not necessarily have to be of the same age as often assumed in earlier approaches. They also point out that no more precise classifications can be made without further reliable chronological data. The isolated generic units are summarized in Fig. 13 (left).

Bosinski's (2000-2001) approach is slightly different (Fig. 13 mid). He distinguished the assemblages of the early Middle Paleolithic according to their age, differentiating between two supergroups in the younger phase, which are separated in time (early and late phase). He distinguished two assemblage types within the early phase (laminar Rheindahliense in MIS 5c, laminar Wallerheim D also in MIS 5c). Within the following Keilmessergruppen (los grupos Keilmesser), he distinguished five assemblage groups, which, in contrast to earlier works, he staggered differently in time. The Keilmessergruppen are placed between MIS 5a and the middle MIS 3. He differentiates between two chronologically successive units, which we would like to call early and late Keilmessergruppen. The early groups contain the types Königsaue, Bockstein, and Klausennische, which are regarded as being chronologically parallel to each other. The late groups consist of the contemporaneous types Lebenstedt and Pradnikhorizont. This structure differed fundamentally from the sequence established by Bosinski (1967). Not only do the types Rörshain (now placed into the 


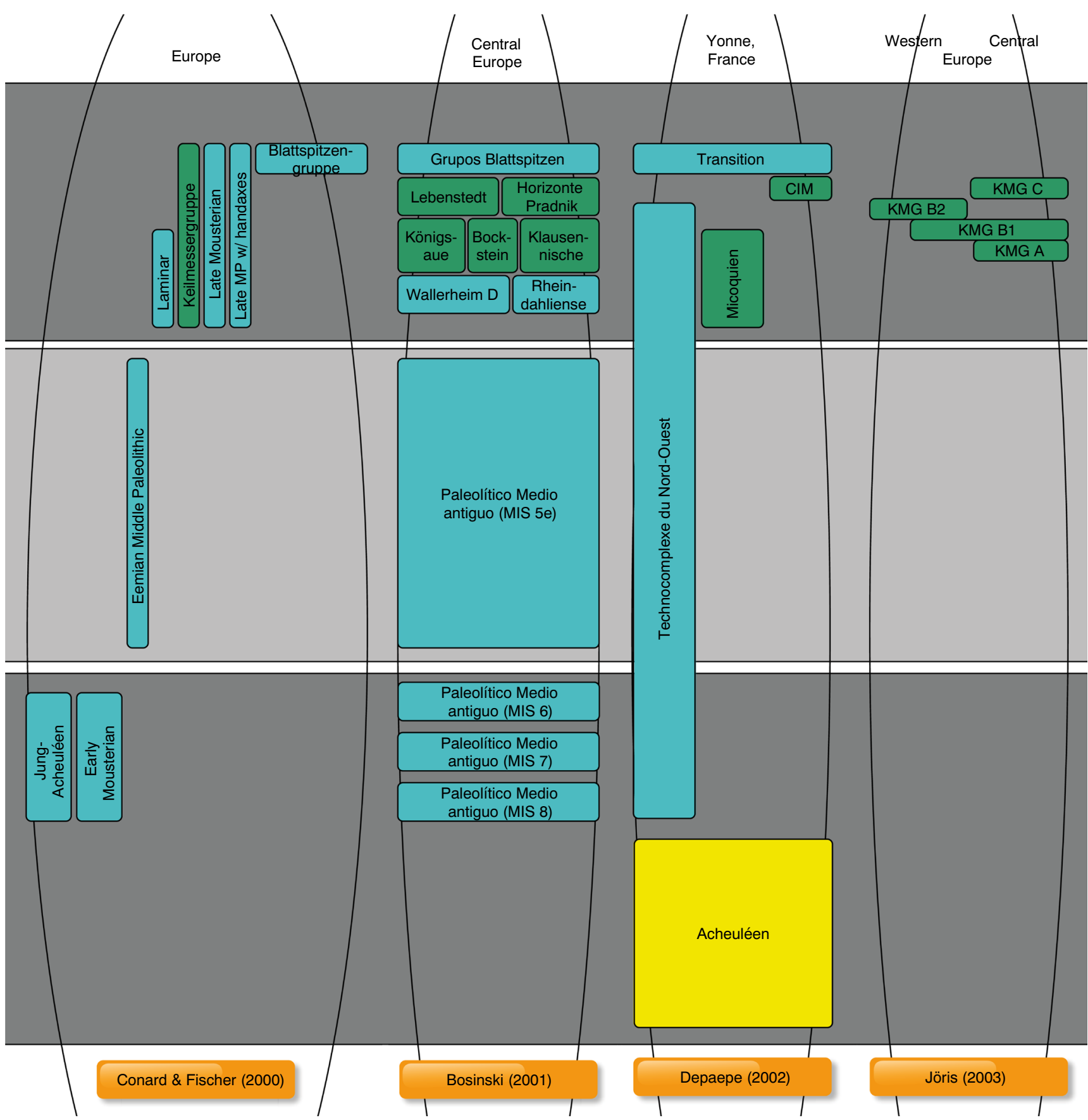

Fig. 13 Cladogram of Micoquian positioning in Western and Central Europe (2000-2003), according to Conard and Fischer (2000), Bosinski (20002001), Depaepe (2002), and Jöris (2003)

Blattspitzengruppen) and Schambach not occur, but the types Königsaue and Pradnikhorizont were also included. In his very early works, Lebenstedt was seen as the type location of the Jungacheuléen, which was located before the Eem (Bosinski 1963).

Böhner (2000, p. 1) sees a clear shift of the Micoquian into the MIS 3 due to dating of newly excavated sites and agrees with the considerations presented by Uthmeier (2004, pp. 381-396) summarizing the assemblages described so far as
Micoquien, Moustérien, Altmühlgruppe, and Szélétien [Obviously, the text of the dissertation available on the Internet is not the submission version from the year 2000, but a revised version. The dissertation was subsequently also published as a book: Böhner (2008)].

In his analysis of the Late Middle Paleolithic and Early Upper Paleolithic in Bavaria, Uthmeier (2004) subsumes the assemblages previously referred to as Mousterian, Micoquian, and Blattspitzengruppen under the generic term Micoquian. 
He refers to the concept of the context area coined by Weißmüller (1995) here, but defines it differently (Uthmeier 2004, p. 297): Micoquian as distribution area of technological and typological features that combine several local groups within the distribution boundaries of a "technocomplex" to form a larger supra-regional unit. On the basis of Richter's (1997) works, he combines the Mousterian and Micoquian of his work area into a single technocomplex. In a similar way, he groups assemblages with leaf points into his regional Micoquian (Uthmeier 2004, p. 299). In his opinion, evaluation units and assemblages with leaf points within Bavaria are part of the regional Micoquian. Therefore, he mapped the Micoquian without leaf points, Micoquian with isolated leaf points $(<5 \%)$, and Micoquian with leaf points $(>5 \%)$ into one map (see Fig. 14).

According to Jöris (2003, p. 53), the term Keilmessergruppen should be preferred to the term Micoquian, because of the presence of specific bifacial tools, especially the Keilmesser. He referred to the discussion in Veil et al. (1994) and chronologically rearranged the complexes defined by Bosinski (2000-2001) within the Keilmessergruppen (KMG). According to the data available at that time, he assumed that the KMG date both before and after the first glacial (MIS 4, see Fig. 13 right). He assumed a period of about 80 to $43 \mathrm{ka}$. In his opinion, the assemblages could be chronologically divided into three groups, which he called KMG A (early), B (middle), and C (late) and which essentially correspond to Bosinski's assemblage types:

- KMG-A: assemblage type "Königsaue-Lebenstedt." Occurs in the north German lowlands, as well as in the northern and southern Central European low mountain ranges. Assemblages dominated by Levallois reduction. Keilmesser and scrapers with convex cutting edges.

- KMG-B1: "Pradnik-Horizont." Northern Central European low mountain ranges. Levallois reduction concepts are almost insignificant, and the systematic extraction of reductions is almost completely absent. Handaxes are rare, domination of Keilmesser with straight cutting edges.

- KMG-B2: not defined for Central Europe. Occurs in Western Europe.

- KMG-C: assemblage type "Bockstein-Klausennische." Northern and southern Central European low mountain ranges. Highly variable shapes of tools, mostly straight cutting edges.

Bosinski (2008) assumes that the majority of the assemblages to be assigned to the Keilmessergruppen are to be placed in the MIS 5a (Odderade), whereby according to Jöris (2003), assemblages belong after the first glacial maximum, and Richter (2002) wants to place the entire Keilmessergruppen (Moustérien mit Micoquien-Option) in the MIS 3 on the basis of ${ }^{14} \mathrm{C}$ data. Bosinski's sequence of assemblages is based on the stratigraphic sequence of the Balve cave, as determined in his doctoral thesis (Bosinski 1967). This approach (Fig. $15 \mathrm{mid}$ ) is congruent to the one he published in 2000-2001 (Fig. 13 mid)

\section{Micoquian research in Western Europe during the 2000s}

So as not to completely go beyond the scope, we limit ourselves to a few (hopefully well chosen) contributions. Let us first take a look at the east of France, where large-scale excavations along a motorway route yielded numerous results. Depaepe (2002) summarized the work in Yonne, northeast France. He extracted four Middle Paleolithic generic units after the Acheulian (Fig. 13 mid) and distinguished two units of "micoquoid" assemblages:

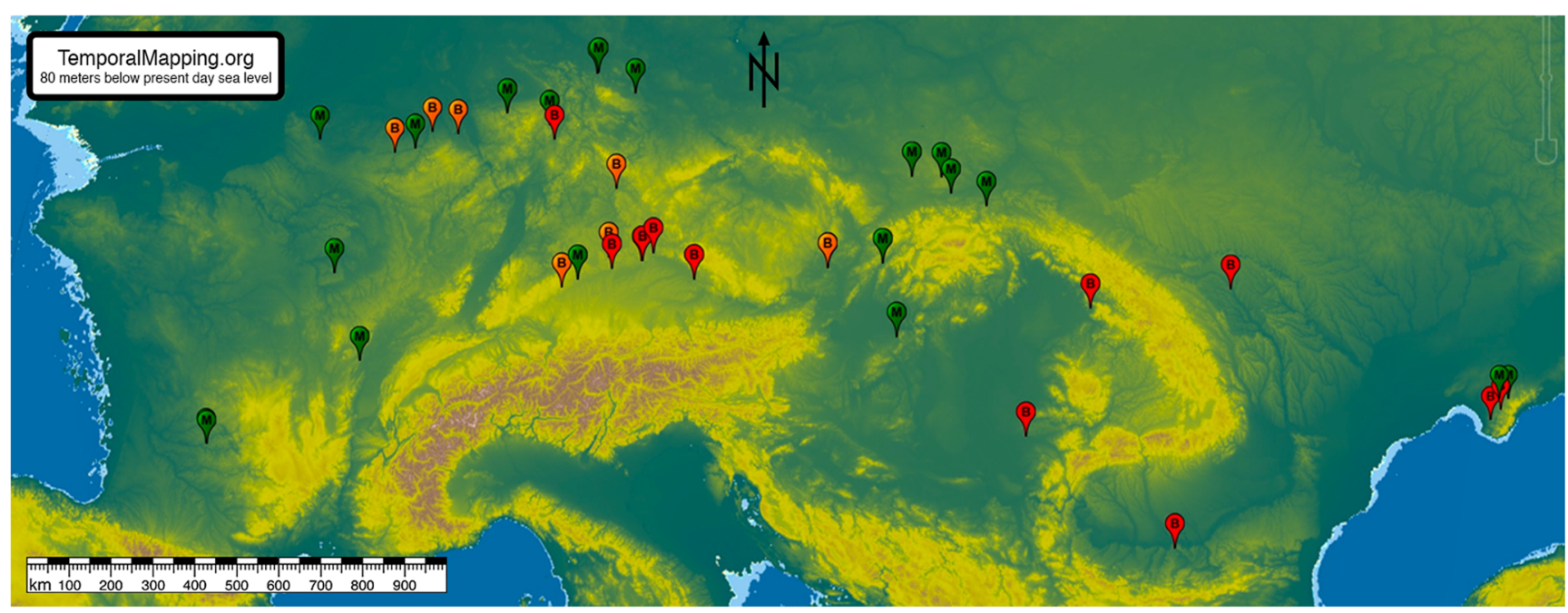

Fig. 14 Sites of the Micoquian with and without leaf points, according to Uthmeier (2004, p. 298, Abb. 11.1) 
Fig. 15 Cladogram of Micoquian positioning in Western and Central Europe (2007-2009), according to Delagnes et al. (2007), Bosinski (2008), and Koehler (2009)

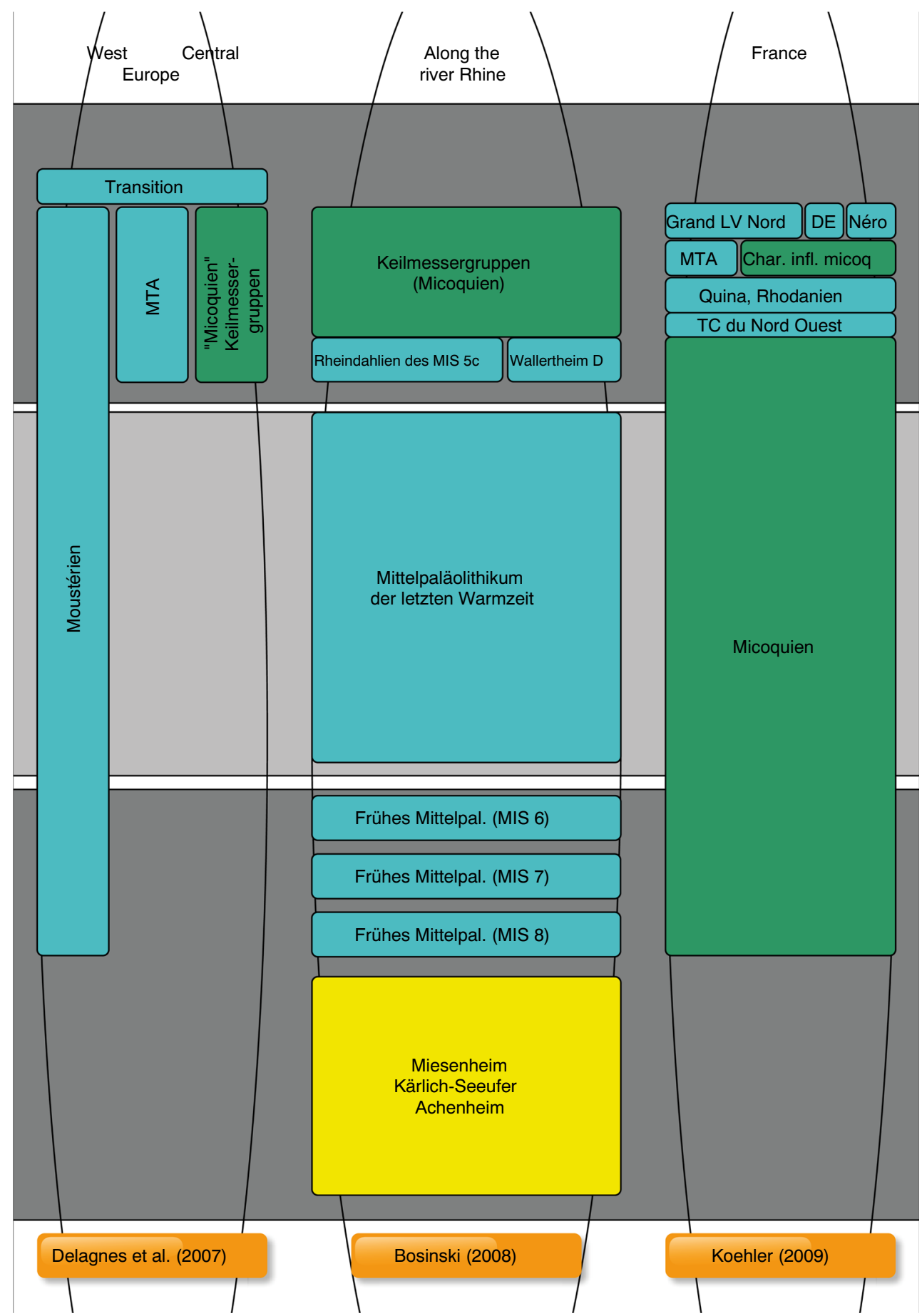

- "Classical" Micoquian with handaxes according to Bordes and Bosinski at Vinneuf $\mathrm{C}$ at the beginning of the Würm glacial (MIS 5)

- CIM (Charentian with Micoquian influence) described by Farizy (1995) at the Champlost site in the middle Pleniglacial (MIS 3)

- Technocomplexe du Nord-Ouest at Le Fond de la Tournerie in Lailly, at Le Domaine de Beauregard in Lailly, at le Grand Chanteloup in Molinons or at La
Prieurée in Villeneuve l'Archevêque from the Saalian (MIS 6) to the early Pleniglacial (MIS 4)

In describing "technocomplexes" in Western and Central Europe, Delagnes et al. (2007) continued the division into mousteroid and micoquoid assemblages. Bifacial pieces can be found in the MTA as well as in the Micoquian. The MTA is present in southwestern France, sporadically in northern France and in England. In contrast, the Micoquian 
(Keilmessergruppen) is mainly concentrated in Central Europe, but similar industries were also reported from Brittany (Molines et al. 2001), Burgundy (Gouédo et al. 1994; Gouedo 1988), and the Périgord (Bourguignon 1992; Brenet and Folgado 2003). In addition, the contemporaneity of the MTA and the Keilmessergruppen was assumed (Fig. 15 left).

Koehler's (2009) approach to technocomplexes in France differs from the previous one in that she attempts to include numerous regional studies in her chronology scheme, thus achieving a finer structure (Fig. 15 right). With regard to micoquoid industries, she distinguishes the Micoquian (Paris Basin, alternating unidirectional edge regularization) from the CIM (numerous often bifacial side scrapers and Levallois reduction; eastern France), whereas the Micoquian is situated in MIS 6 to $5 \mathrm{~d}$ and the CIM in MIS 4 to 3. All these French approaches are based on a single, uniform Late Middle Paleolithic industry (Keilmessergruppen) in Central Europe. The works of Bosinski (1967, 2000-2001, 2008) or Conard and Fischer (2000), however, show the complexity of the Middle Paleolithic in western Central Europe and different generic units.

\section{Micoquian research in Western and Central Europe during the 2010s}

More recently, the term Micoquian has been used mostly in conjunction with the term Keilmessergruppen. However, we will first compare the approaches of Baales (2013) and Kozłowski (2014) favoring a short chronology for the western part of Central Europe (Fig. 16 left) and a long chronology for the eastern part of Central Europe (Fig. 16 right), respectively. For Baales, Keilmessergruppen (Micoquian) and Mousterian are generic units running side by side, while the Keilmessergruppen (Micoquian) only occur between MIS 5b and MIS 3. This is in contrast to the Mousterian, which appears from MIS 8 to MIS 3. For Kozłowski, there are three units: a pure Mousterian, a pure Micoquian, and a mixture of both.

Richter (2014) takes a slightly different approach (Fig. 16 left). While the Micoquian sensu lato has a long chronology (MIS 7 to MIS 3), the position of the M.M.O. (Mousterian with Micoquian Option) is exclusively in MIS 3. The eastern Micoquian has a somewhat longer chronology (MIS 5 to MIS 3). The MTA in Western Europe is contrasted with the M.M.O. in Central Europe. In addition, for the early MIS 3, he designed a model of five European settlement zones (Richter 2014, p. 203):

- Northwestern Europe - different Mousterian facies

- Southwestern France-classical MTA and other Mousterian facies
- Central Europe (from the Rhine to the Carpathian Mountains) - industries with Keilmesser (Central European Micoquian or M.M.O.)

- Eastern Europe (from the Carpathian Mountains to the Ural) _ eastern Micoquian and different Mousterian facies - Southern Europe (Balkan)_-different Mousterian facies

In his overview of the European Middle Paleolithic, Depaepe (2014) made it clear that the facies model built by François Bordes has a spatial limitation. This quickly became visible for other regions by adopting the model and led to the definition of own generic units, which better described the features recognized. Figure 16 (mid) shows an attempt to represent the generic units described by Depaepe in a cladogram. He recognized that the term Mousterian is nearly synonymous to the term Middle Paleolithic. For the Micoquian, he defines two phases: phase 1 -Keilmessergruppen and phase 2 Blattspitzengruppen. This corresponds to the approach advocated by Richter (2014), whereby the M.M.O.-A and B correspond to the Keilmessergruppen and the M.M.O.-C to the Blattspitzengruppen. He also sees connections between the Micoquian, on the one hand, and the Babonyan, Szeletian, and Altmühlian, on the other hand. To complete this approach, Depaepe examines the chronological range of various lithic reduction concepts. He attests Levallois and Discoidal a long chronology. In contrast, Quina and Laminar occur only toward the end of the Middle Paleolithic.

Last but not least, in this chronological view of the term Micoquian, we would like to present and contrast three models from the year 2016 with very different approaches to deal with the Micoquian controversy. First, we consider the approach of Blaser and Chaussé (2016), who compiled the definitions of the term Micoquian for assemblages from the Paris basin. They make two remarkable observations. First, they can show that the Micoquian biface (or what has been described as such) is not suitable for forming generic units. Second, they can show that a total of three temporally separated generic units were described as Micoquian (Fig. 17 right). Due to the use of the term Keilmessergruppen, which is now increasingly used in Central Europe, they propose to form a separate term for the industries at the beginning of the last glaciation (but make no proposal).

Locht et al. (2016), who avoid using cultural allocations or generic units to describe the assemblages wherever possible, consider the production systems for flakes, blades, points, and bifaces in each chronostratigraphic phase for northern France (MIS 7 to early MIS 3). They come to the conclusion that the individual reduction systems do not always occur and that bifacial elements are only sporadically present in individual units (Fig. 17 left). The approach chosen by Kozłowski (2016) for the eastern part of Central Europe uses generic units and recognizes a juxtaposition of these Mousterian and Micoquian industries (Fig. $17 \mathrm{mid}$ ). 


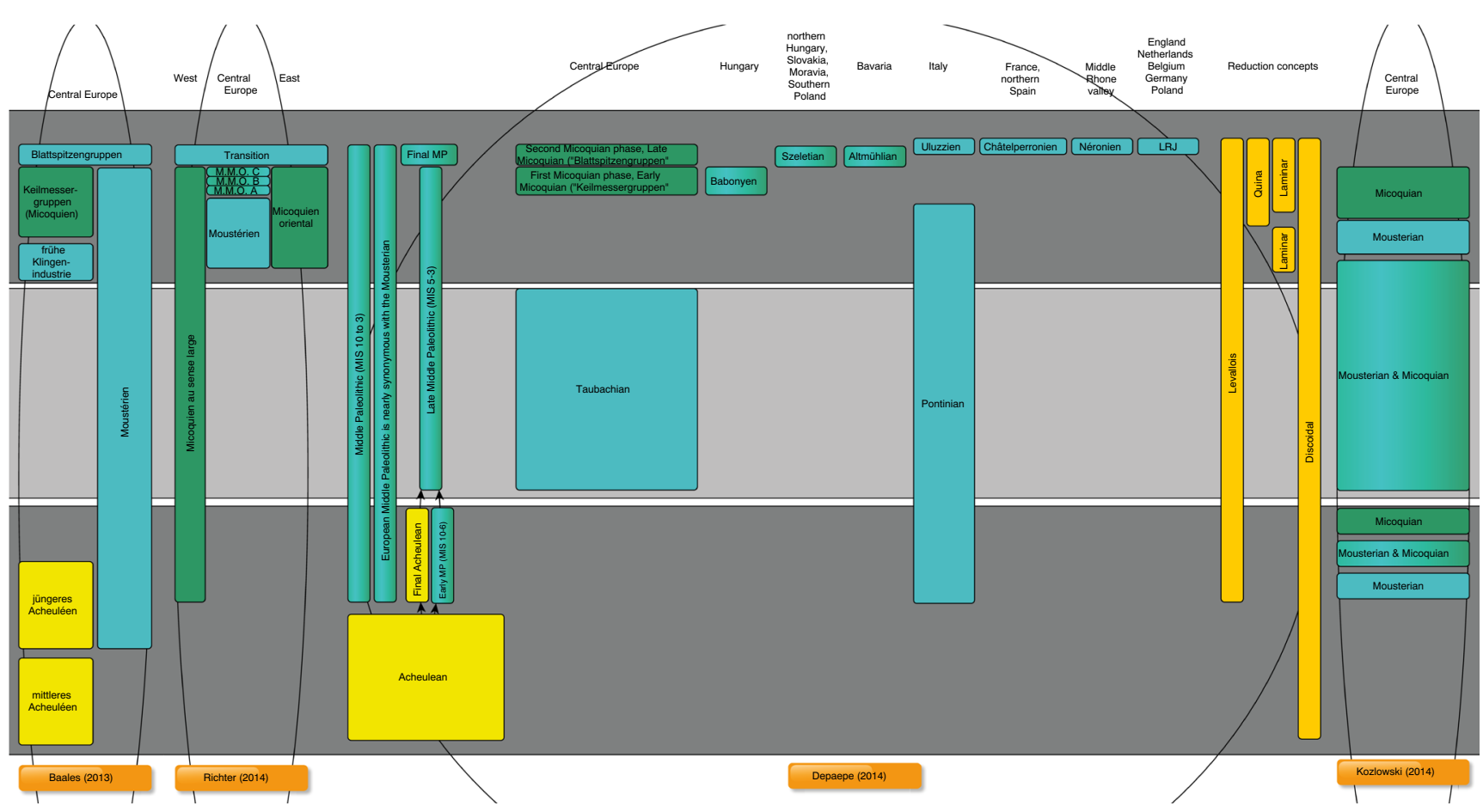

Fig. 16 Cladogram of Micoquian positioning in Western and Central Europe (2013-2014), according to Baales (2013), Richter (2014), Depaepe (2014), and Kozłowski (2014)

\section{Discussion}

\section{Shifts in chronological and epochal affiliation}

In the course of more than 100 years of Paleolithic research, in which the term Micoquian was used as a generic unit, several chronological shifts of the term's use can be observed. A total of 58 sources were used, in which clear information on the chronological position and its affiliation was given (Fig. 18). It is good to see that there is an interplay between the affiliation to the Lower (Acheulian) or Middle Paleolithic (starting right from the beginning of the use of the term). From the 1950s onwards, the assumption that the generic unit Micoquian can be attributed to the Middle Paleolithic prevails. Predominantly French authors continue to use the term Micoquian according to Breuil and Bordes and declare the assemblages to belong to the Acheulian. The term was thus not only increasingly used for chronologically younger assemblages, but also underwent a spatial shift from Western Europe to Central and Eastern Europe. The sources used show five significant shifts of meaning:

1. Discovery phase (1908-1932)

2. Würmian phase (1951-1969)

3. Chronological expansion phase (1977-1989)

4. New naming and Würmian phase (1990-1993)

5. Chronological expansion but Würmian manifestation phase (2014 to today)
The discovery phase (1) is characterized by a repeated change in affiliation, although the chronological assignment to the last interglacial is retained. In the Würmian phase (2), a twofold shift is visible: on the one hand, the chronological assignment of the assemblages to the last glacial, and on the other hand, to the Middle Paleolithic. In the chronological expansion phase (3), the duration of the Middle Paleolithic was extended to the time before the last glacial period, and thus, numerous assemblages were also assigned to the Middle Paleolithic. In the new naming and Würmian phase (4), a new name for the corresponding assemblages was defined with the term Keilmessergruppen and an assignment to the last glacial was manifested. In the newest phase (chronological expansion but Würmian manifestation phase, 5), two tendencies are visible: on the one hand, a manifestation in the last glacial, and on the other hand, an extension of the definition to older assemblages.

\section{Spatial shifts in affiliation}

The spatial shift of the affiliation of assemblages to the Micoquian is closely related to the question of whether the eponymous site La Micoque should be added or not. In the descriptions before 1990, a reference (explicit or not) to the eponymous site La Micoque was repeatedly made, either through the similarity of the assemblages or through the use of the term Micoquian. From the 1990s onwards, La Micoque was increasingly detached. This 


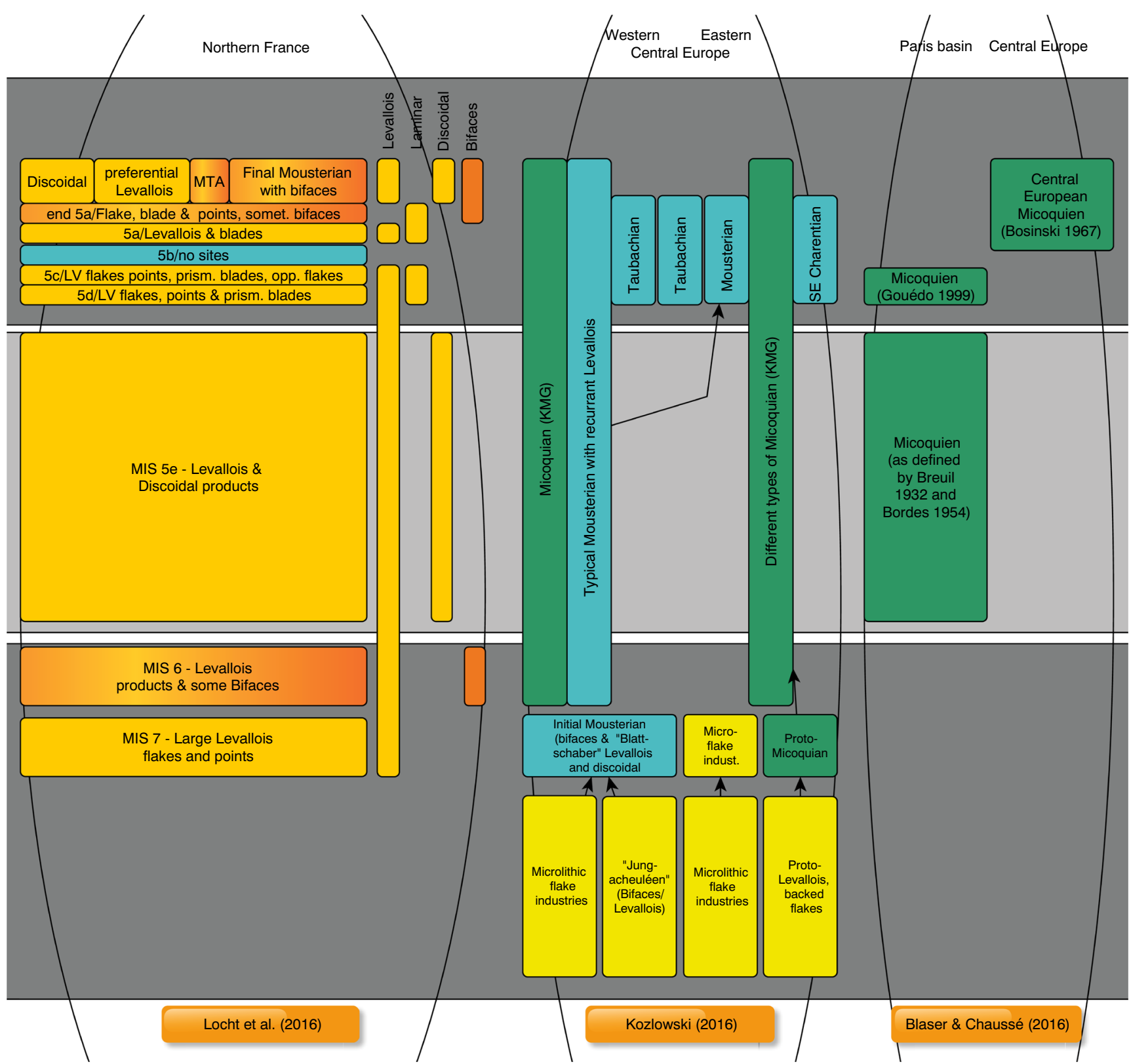

Fig. 17 Cladogram of Micoquian positioning in Western and Central Europe (2016), according to Locht et al. (2016), Kozłowski (2016), and Blaser and Chaussé (2016)

took place with the reference to the spatial distance of the sites, the undated layer N/6 in La Micoque, as well as the now recognized differences in the assemblages. One the one hand, despite the spatial distance, Bosinski $(1967,1970)$ explicitly interpreted the micoquoid assemblages he analyzed in Central Europe with reference to la Micoque. On the other hand, despite the name connection (Micoquo-Pradnikien), Chmielewski (1969) drew attention to the differences between the Central European assemblages and the eponymous site. The distribution of the Micoquian strongly depends on whether the eponymous site is part of the respective definition (see Figs. 2, 6,8 , and 14).

\section{Assigning new names}

Looking back to the 1990s, the differences between the eponymous site and the Central European assemblages were emphasized more intensively. Veil et al. (1994, p. 40) summarize the reasons for replacing the term Micoquian with a more appropriate one and point out that the lithic of the eponymic layer (La Micoque N/6) is not considered to be typical for the whole of what is now considered to be part of this group in Central and Eastern Europe. The mentioned difficulties with the eponymous site, as well as the fact that other northern French complexes were also called Micoquian, led to the search for a new term. Veil et al. (1994, pp. 40-41), as well 


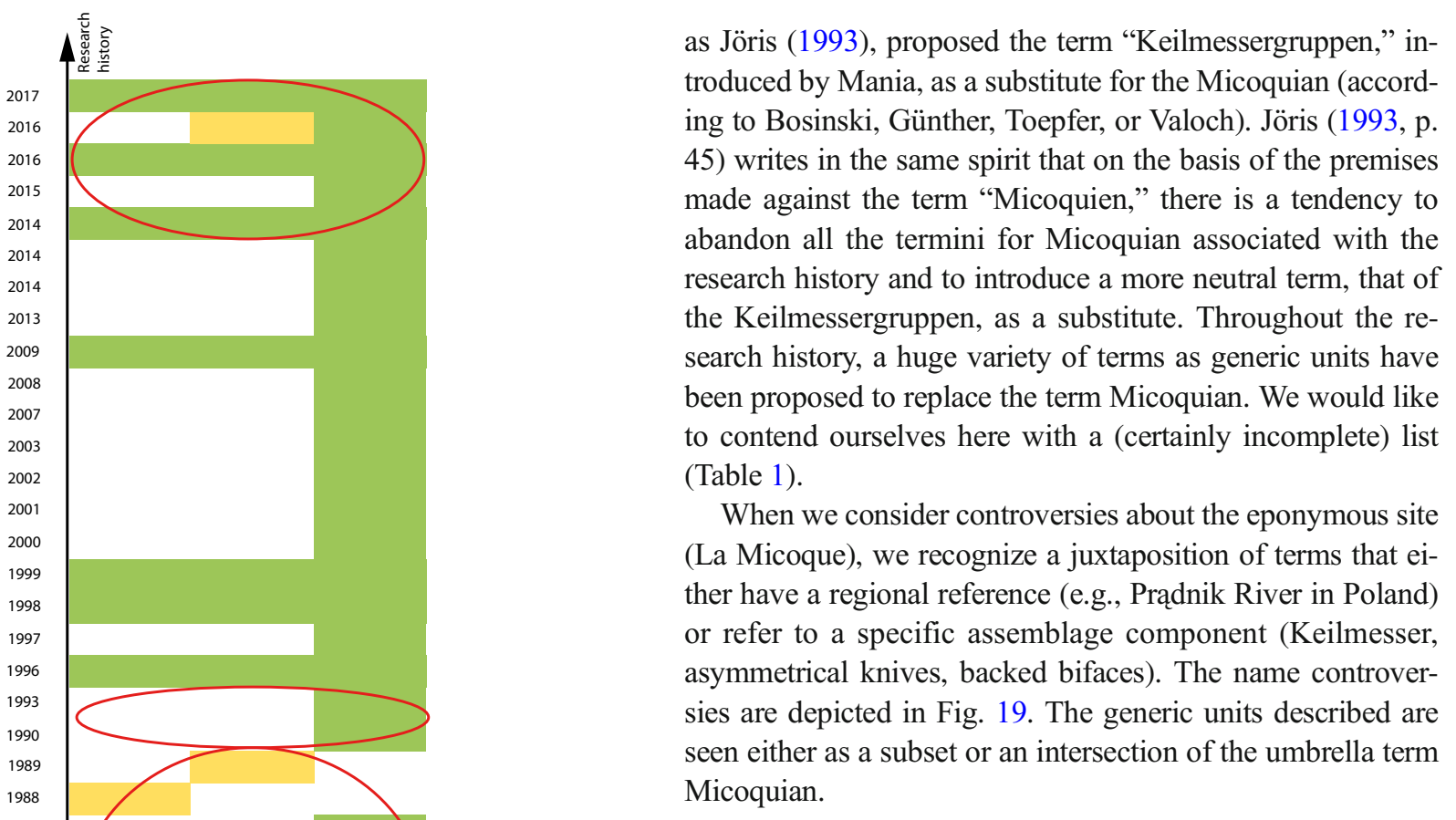

Shifting the focus of bifacial elements

At the beginning of the Micoquian research, the focus was on the preference of bifaces, which looked similar to pieces from la Micoque but different from comparable pieces from, e.g., Le Moustier. The importance of pieces that were mentioned from the 1940s onwards as Keilmesser, Faustkeilschaber, etc. (asymmetrical backed knives) in determining whether they belonged to a generic unit increased successively. Along with this added value, which bifacial pieces are now decisive, the spatial and temporal shift also came about. Thus, the meaning of the term Micoquian in more recent studies differs massively from what was regarded as Micoquian in the first half of the twentieth century.

\section{Linking the Mousterian with the Micoquian}

The attempt to systematically link the research approaches of the term Mousterian and Micoquian has been repeated in research. While at the beginning the industry of La Micoque was regarded as part of the Acheulian (Obermaier 1908a) or as transitional industry (Schmidt 1911, 1912a), the idea also arose that the Micoquian should be placed in the Middle Paleolithic. This raised the question of the simultaneity of Mousterian and Micoquian. The term Middle Paleolithic (Mittelpaläolithikum) was already introduced 10 years earlier (Blankenhorn 1905) and taken as a synonym for the Mousterian (see also Sollas 1911). The decisive difference, however, was that Hauser placed the Micoquian between the Mousterian and the Aurignacian, and Wiegers saw it as the Lower Mousterian. Perhaps Breuil (1932b) was the first to
Fig. 18 Diagram of the Micoquian's chronological positioning in the course of the research history 
Table 1 Variety of terms of generic units to replace the term Micoquian

\begin{tabular}{|c|c|c|}
\hline Term & Translation & Literature \\
\hline $\begin{array}{l}\text { Cykle przemystowe - mikocki i } \\
\text { pradnicki }\end{array}$ & $\begin{array}{l}\text { Industrial cycles of the Micoquian and } \\
\text { Pradnikian }\end{array}$ & $\begin{array}{l}\text { Krukowski } \\
\quad(1939-1948)\end{array}$ \\
\hline Bocksteinkultur & Bockstein culture & Wetzel (1954) \\
\hline $\begin{array}{l}\text { Oberes Altpaläolithikum mit } \\
\text { Faustkeilschabern }\end{array}$ & $\begin{array}{l}\text { Upper Lower Paleolithic with } \\
\text { handaxe-scrapers }\end{array}$ & $\begin{array}{l}\text { Müller-Beck (1956, } \\
\text { 1957) }\end{array}$ \\
\hline Charentien of Micoque tradition & Charentien of Micoque tradition & Valoch (1968) \\
\hline Micoquo-Prodnikien, Prondnikien & Micoquo-Pradnikian, Pradnikian & $\begin{array}{l}\text { Chmielewski (1969, } \\
\text { 1970) }\end{array}$ \\
\hline Group of backed bifaces & Group of backed bifaces & $\begin{array}{l}\text { Schild and Wendorf } \\
\text { (1977) }\end{array}$ \\
\hline Keilmessergruppen & Keilmesser groups & Mania (1990) \\
\hline Charentien à influence micoquienne & Charentian of Micoquian influence & Farizy (1995) \\
\hline Moustérien mit Micoque-Option & Mousterian with Micoquian Option & Richter (1997) \\
\hline $\begin{array}{l}\text { Prondnikian, backed biface } \\
\text { assemblages }\end{array}$ & Prondnikian, backed biface assemblages & Burdukiewicz (2000) \\
\hline Asymmetrical knives assemblages & Asymmetrical knives assemblages & Urbanowski (2003) \\
\hline $\begin{array}{l}\text { Keilmessergruppe } \\
\text { (Micoquian/Pradnikian) }\end{array}$ & $\begin{array}{l}\text { Keilmessergruppe } \\
\text { (Micoquian/Pradnikian) }\end{array}$ & Conard (2011) \\
\hline
\end{tabular}

juxtapose the Micoquian (Acheulian VI-VII, now limited to layer N/6) and the Mousterian (see Fig. 3).

Two newer approaches are briefly examined in more detail here. We want to call the first approach an extension of typology. Valoch $(1968,1988)$ recognized during the analysis of the lithics from Kulna that the common typology established by Bordes (1961b) was only insufficiently suitable to describe the assemblage variability. This was particularly visible in relation to bifacial pieces (Keilmesser) or special scrapers (Groszaki). Quintessentially, he described the assemblage
Fig. 19 Name controversies in regard to the terms Micoque, Prądnik and lithic assemblage component

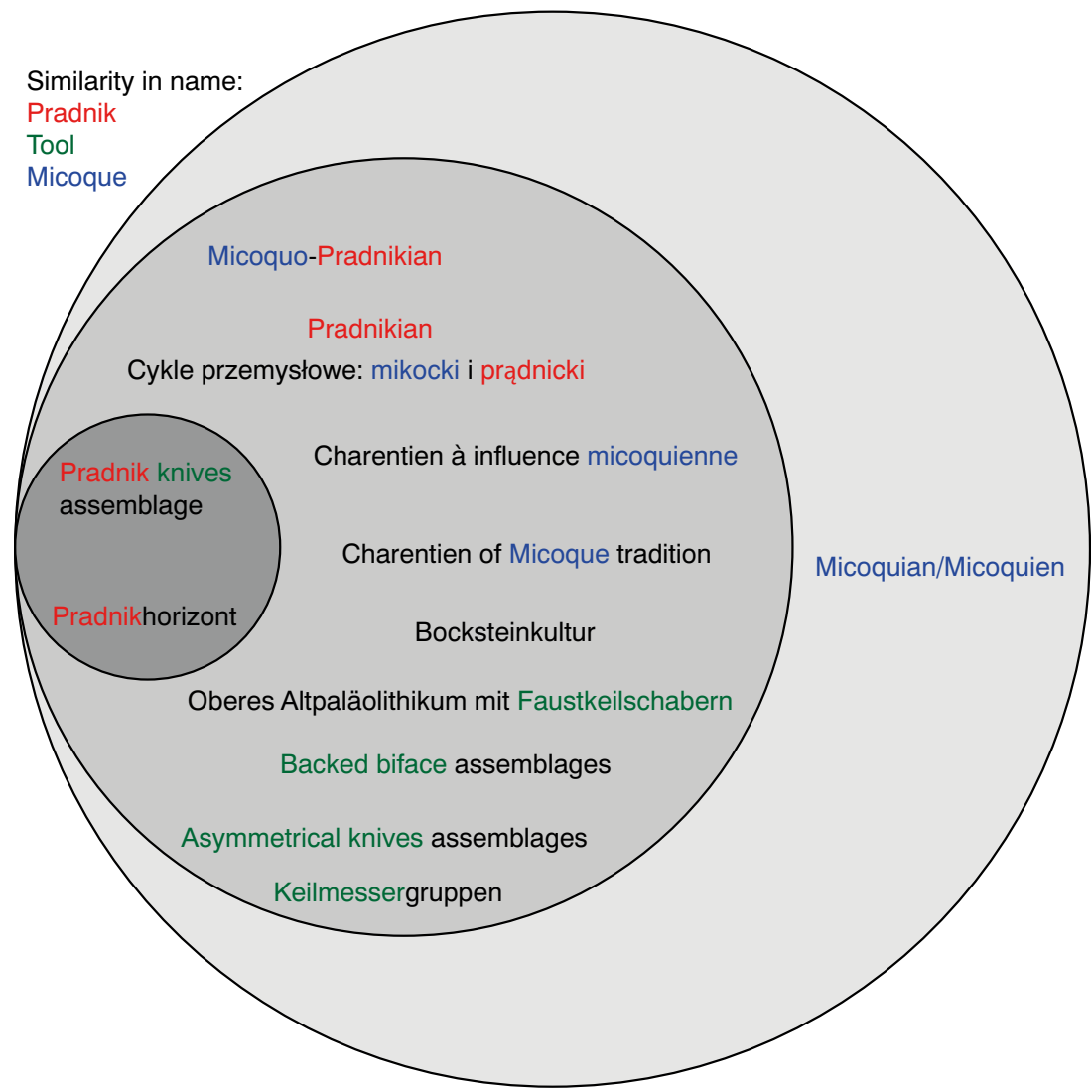


added by him to the Micoquian as a Charentian with Micoque tradition, pointing out the special significance of scrapers and special bifacial pieces, which did not occur in the Bordesian facies (Bordes 1953a, 1984 defined the Charentian as Quina or Ferrassie industry with a predominance of side scrapers, but relatively few handaxes and blades). In this case, both the bifacial assemblage component (Micoque tradition) and the unifacial assemblage component (Charentian) were emphasized.

The second approach extends the consideration of unifacial and bifacial assemblage components by a settlement dynamic element and was described by Richter (1997, 2002, 2006, 2014, 2016, 2018) as Mousterian with Micoque Option. His approach is based on the observation that in a conventional typological classification, the problem arises that assemblages can be called both Micoquian and Mousterian, depending on whether the affiliation is derived from bifacial tools (Micoquian) or unifacial tools (Micoquian). Thus, Micoquian and Mousterian are interwoven aspects of the same technological repertoire, but not different cultural units that can be clearly distinguished in time and space (Richter 2016, p. 118). The settlement dynamic momentum of this approach is based on the assumption that when a site or area is repopulated, other objects are deposited than if it had been settled there for a longer period of time. On the one hand, a repopulation assemblage (Initialinventar) is characterized by high raw material diversity, indifferent tool spectrum, and a low number of Micoquian tools. On the other hand, such a long duration assemblage (Konsekutivinventar) is characterized by a lower raw material diversity, a differentiated tool spectrum, and a high number of Micoquian tools. A question that keeps coming up is exactly what status bifacial tools constitute in this cycle. For Richter (2016, pp. 118-119), bifacial tools, at the beginning of land use cycles, tend to reflect their initial status, but at the end of the cycle, they tend to be more strongly reduced. The difficulty here in this approach for us lies in the fact that the M.M.O. model tries to unite all Central European sites in one model and to compare this model with a selected section of sites (MTA) in Western Europe (see Richter 2014).

\section{Structuring by means of the unifacial assemblage component}

Within the assemblages referred to as Micoquian/KMG/ M.M.O., etc., the unifacial assemblage component was sometimes used to structure them. Thus, Richter differentiated his M.M.O. into an older one (with Quina and other nonLevallois concepts) and a younger one (with Levallois concept). This unambiguous temporal differentiation of the assemblages must be accompanied by some remarks that have been compiled in the literature. We selected some examples of assemblages which can no longer be sorted into the M.M.O. model so clearly.
Let us first turn to the eponymous site (La Micoque). The upper strata in La Micoque remain undated despite several attempts (Rosendahl 1999, 2004, 2006, 2011). However, an age of about 300 to $250 \mathrm{ka}$ is assumed (Rosendahl 2006), meaning that these assemblages would fall out of Richter's time frame. As Rosendahl (2004, 2006, 2011) discovered, the assemblages of the upper layers (layer 6 to 8 ) are dominated by the reduction of "ingot-shaped cores" (according to Luttropp and Bosinski 1971). The Levallois and Discoidal concept is present but very rare. However, there is no evidence for Quina reduction. This would fit into the older M.M.O. according to Richter's model.

Another site considered here is the Bockstein. The faunal analysis by Krönneck (2012) assumes a probable deposition of the Micoquian assemblage (IIIa, IIIl) in the MIS 5a (or a warmer phase of MIS 5). This would fit into the older M.M.O. according to Richter's model, but not in the model of the KMG proposed by Jöris (2003), where the Bockstein site is placed into the MIS 3. The unifacial reduction of the site, however, is not so easy to grasp. Çep $(2014,2019)$ and Çep and Krönneck (2015) described it as a Quina concept in the broader sense, which carries a certain Levallois reduction. This raises the question of whether the reduction concepts for blank production have been sufficiently well described and separated from each other so far (Frick 2016, pp. 215-218; Frick and Herkert 2014).

\section{Possibilities and ideas for overcoming the term Micoquian}

According to our understanding of the matter, the approach described below could help to overcome these inconsistencies. However, we must stress that this hypothetical construct is still far from mature and applicable. As described above, the term Micoquian was used in a variety of different ways to form generic units. If we look at the latest uses of the term, there is no uniformity here either. If the aforementioned M.M.O. is equated with the Keilmessergruppen, Richter $(1997,2002,2014,2016,2018)$ assumes a very short chronology (exclusively MIS 3), while Jöris (2003) proposed a longer chronology (MIS 5 to 3) and Kozłowski (2014, 2016) applies an extended chronology (MIS 7 to 3). These massive differences in the application of the term make it difficult to compare the respective approaches.

Let us now move on to the approach proposed here for the classification of assemblages. As we have seen, over the decades, the bifacial assemblage component was first chosen intensively in order to assign the assemblages to a generic unit. Over time, the unifacial component has also been used. With a similar intensity, the further method apparatus was expanded within Paleolithic research (faunal remains, sedimentology, radiometric dating, settlement dynamic, etc.). We would therefore like to make use of this expansion of knowledge and the apparatus of methods to develop a classification system for the Middle 
Paleolithic. As lithologist, it is our intention to expand and specify the methodological apparatus of lithic technology. With this in mind, it must be examined:

- Whether there are transitions between the concepts of unifacial reduction, as well as bifacial and trifacial production already described

- Whether only inadequately described concepts need to be specified

When the assemblage components are described and a chronological framework exists, the assemblages are compared to one another. Similarly, Locht et al. (2016), Hérisson et al. (2016), or Soriano (2000) also tried to describe assemblages according to the reduction concepts and to fix them chronologically.

In other words, it is the attempt (as unbiased as possible) to get a clear understanding of the situation on the basis of technological and radiometric data (and by consulting further data). If we determine the types of assemblages chronologically piece by piece, it should be possible to recognize the respective patterns. It goes without saying that we are always confronted with the dynamics of settlement: not in terms of population shifts but in terms of different types of camp sites, which can have very different assemblages, depending on what is needed at the particular site before deposition (in terms of import, export, deposition, reduction, modification, or recycling). Here, generic units are irrelevant, because it must first be clarified (in relation to the lithic assemblage component) to what extent the unifacial, bifacial, and trifacial reduction systems analyzed in detail relate to one another.

\section{Conclusion}

In considering the research history of such a complex and controversial term, it is difficult to draw an appropriate conclusion that adequately takes into account the different opinions. First and foremost, the aim of this article is to show the complicated and intricate ways of researching the concept of Micoquian. It was demonstrated that a shift in the meaning of the term was made several times (see Fig. 18). This concerned its position within the chronology, its spatial extent, and the decisive assemblage components. The shift in meaning is associated with different levels of reflexivity or the question of which methodological apparatus should be used to analyze the underlying lithic artifacts.

The shifts in meaning are therefore closely related to the change in the way lithic assemblages are analyzed. In the early phase, the index fossil (in this case the Micoquian biface) was the point of reference for the assignment to a generic unit. The typological considerations since the 1950 s took into account a larger number of pieces, pushing the biface somewhat into the background, but it turned out that the unifacial assemblages were hardly distinguishable from classical Mousterian assemblages. With the increase of technological analyses from the 1980s onwards, assemblages were not only examined for their specific (static) lithic components, but the dynamic momentum of assemblages was also reflected. Some authors who became aware of this problem of the different levels of observation avoided these difficulties by either proposing a name for a defined generic unit or attempting to dispense with these generic units in order to take into account the assemblage components in their respective position in space and time.

It is very significant when three chronologically separated and technologically different units (Bordesian Micoquian, pre-Eem; Yonne Micoquian, MIS 5; and Charentién à influence micoquienne, MIS 3) within a region are labeled with the same term, as Blaser and Chaussé (2016) could show for the Parisian basin. In addition, it appears that these three units have little correspondence with the assemblage of the eponymous site La Micoque.

After this extensive (but certainly not complete) discussion of the use of the term Micoquian, the question remains as to whether the term should continue to be used or whether it is time to classify the Middle Paleolithic using new approaches. However, the simple assignment of a new name to a defined unit may not always be the most elegant way. The assignment of a new name should be strictly linked to the definitions of a technocomplex. Recalling the aforementioned definition ((Lithic) assemblages that share the same economic strategy, in similar environments with a similar technology and a similar trajectory) and supplement it with a narrow chronological framework, we should be able to form generic units that can be visibly separated from other units and perhaps even hint at certain settlement patterns.

As, for example, showed by the work in southwest France, it is necessary to build up and refine a regional chronological framework with which interassemblage comparisons are increasingly made possible (Jaubert 2011, 2014). However, in this context, it is important to include assemblages that are "out of the ordinary" in the considerations. On the one hand, we think of decontextualized assemblages, which can be added to models by new patterns of observation; on the other hand, we think of technologically unusual assemblages, which, for the time being, cannot quite be integrated into the already existing picture.

The essential definitions of generic units are derived from the consideration of the lithic assemblage component; therefore, it is important to include other disciplines in the reflections. The approach of Delagnes and Rendu (2011), for example, combines the data on lithic production systems and fauna and was thus able to show correlations that could previously only be conjectured, such as the differences in subsistence strategies between Laminar/Levallois systems, Discoidal-Denticulate, MTA, and Quina reduction systems. Due to the enormous amount of data to be processed, these large-scale reflections 
have only been possible since a short time, but they open up numerous possibilities for us to combine the partial results of Paleolithic disciplines in order to look at the finds anew and, if necessary, make changes in the generic units. From our lithic point of view, however, it is not only necessary to merge the data, but also to intensively reflect on the lithic reduction systems already recognized and their variations in order to use them as a lithic basis for regional and supraregional comparisons. Sometimes, it turns out that the intensive technological examination can uncover further, previously unknown reduction systems (e.g., Boëda 1991b, 2013; Bourguignon 1996; Çep 2014; Delagnes 1993, 2000; Frick and Herkert 2014; Luttropp and Bosinski 1971; Slimak 2004), which can be incorporated into the corpus as a basis for further considerations and comparisons. Based on these reflections, we come to the conclusion that the previous terms that were used as names for generic units can only be seen as umbrella terms or coarse units until the underlying assemblages are sufficiently understood to map settlement, movement, and subsistence patterns.

Acknowledgments This contribution arose from our desire to understand when the term Micoquian was used, how it was used, and for what purpose. If there are inconsistencies, they are due to me not accurately understanding certain facts. I would like to dedicate this contribution to Hansjürgen MüllerBeck, who encouraged me to reflect intensively on Paleolithic phenomena. My thanks go to Dominique Rose for her excellent linguistic review of the manuscript and the discussions with many colleagues, greatly enriching the content. I would also like to thank the reviewers and editors of the journal who ensured that the manuscript was transformed into an article worth publishing. The web page for downloading the map layers with sea levels (see Fig. 2, 8, 14), which was used in GoogleEarth as base map (www.temporalmapping.org) can no longer be accessed (last access in 2016). The cladogrammes also represent my interpretation of the respective facts and are not to be seen as absolute chronological fixations.

Funding information Open Access funding provided by Projekt DEAL. This study was funded by the Deutsche Forschungsgemeinschaft (DFG, German Research Foundation) (grant number DFG FR 4015/1-1).

\section{Compliance with ethical standards}

Research does not involve human participants and/or animals.

Conflict of interest The author declares that he has no conflict of interest.

Open Access This article is licensed under a Creative Commons Attribution 4.0 International License, which permits use, sharing, adaptation, distribution and reproduction in any medium or format, as long as you give appropriate credit to the original author(s) and the source, provide a link to the Creative Commons licence, and indicate if changes were made. The images or other third party material in this article are included in the article's Creative Commons licence, unless indicated otherwise in a credit line to the material. If material is not included in the article's Creative Commons licence and your intended use is not permitted by statutory regulation or exceeds the permitted use, you will need to obtain permission directly from the copyright holder. To view a copy of this licence, visit http://creativecommons.org/licenses/by/4.0/.

\section{References}

Adam KD (1969) Zur Großgliederung der Altsteinzeit Europas. Stuttgarter Beiträge zur Naturkunde aus dem Staatlichen Museum für Naturkunde in Stuttgart 207:1-16

Andree J (1930) Über die deutschen Benennungen eiszeitlicher Kulturstufen. Nachrichtenblatt für deutsche Vorzeit 6:8-11

Andree J (1939) Der eiszeitliche Mensch in Deutschland und seine Kulturen. Verlag von Ferdinand Enke, Stuttgart

Baales M (2013) Das Eiszeitalter - Klima, Geologie und Umwelt. In: Baales M, Pollmann H-O, Stapel B (eds) Westfalen in der Alt- und Mittelsteinzeit. Landschaftsverband Westfalen-Lippe, Münster, pp 21-35

Bailloud G, Daniel M, Daniel R, Sacchi C (1973) Les gisements préhistoriques du bois de Verrières-le-Buisson (Essonne). II. Gisement I, atelier de taille campignien. GalliaPrHist 16:105-129. https://doi.org/10.3406/galip.1973.1439

Balout L (1967) Terminologie préhistorique et Quaternaire. Bulletin de l'Association Française pour l'Étude du Quaternaire 4:103-111. https://doi.org/10.3406/quate.1967.1053

Bárta J (1990) Mittelpaläolithische Funde im Gebiet der Slowakei. Ethnographisch-Archäologische Zeitschrift 31:122-134

Basse de Ménorval E (1966) Ancienne circonscription de Paris. GalliaPrHist 9:437-446

Baudet J-L (1970) Contributions à l'Étude du Paléolithique ancien d'Europe septentrionale. In: Gripp K, Schütrumpf R, Schwabedissen H (eds) Frühe Menschheit und Umwelt. Teil 1 Archäologische Beiträge. Festschrift Alfred Rust. Fundamenta Monographien zur Urgeschichte, vol A2. Böhlau, Köln, pp 34-51

Baudouin M (1913) Le Paléolithique inférieur et moyen de la Vendée. Chelléen, Acheuléen et Moustérien. In: Baudouin M (ed) Huitième Congrès préhistorique de France. Session d'Angoulême 1912. Congrès préhistorique de France, Paris, pp 1-76

Bayer J (1920) Das Alter von La Micoque. PZ 11-12:204-208

Bégouën H (1915a) Hauser et la Science Allmande. L'Anthropologie 26: 293

Bégouën H (1915b) Suite de l'affaire Hauser. L'Anthropologie 26:480 488

Benet-Tygel S (1944) The Paleolithic period in Poland. Am Anthropol 46:292-316. https://doi.org/10.1525/aa.1944.46.3.02a00020

Birkner F (1918a) Die Kultur von La Micoque. WPZ 5:1-13

Birkner F (1918b) Hauser Micoquien. Korrespondenz-Blatt der Deutschen Gesellschaft für Anthropologie, Ethnologie und Urgeschichte 49:7-12

Blanchard J (1948) La préhistoire en France. La Terre et la vie 1948:6789

Blanchard J (1963) Bifaces Micoquiens (La Micoque et Bellême). BSPF 60:48-56. https://doi.org/10.3406/bspf.1963.3880

Blankenhorn DM (1905) Über die Steinzeit und die Feuersteinartefakte in Syrien-Palästina. ZfE 37:447-471

Blaser F, Chaussé C (2016) Saint-Illiers-la-Ville and the Micoquian of Weichselian sequences of the Paris Basin. Quat Int 411:163-178. https://doi.org/10.1016/j.quaint.2015.06.035

Boecking H (1971) Paläolithische Quarzitfundstellen im TrierLuxemburger Land. Quartär 22:125-141. https://doi.org/10.7485/ QU22 08

Boëda É (1991a) Approche de la variabilité des systèmes de production lithique des industries du Paléolithique inférieur et moyen: chronique d'une variabilité attendue. Techn Cult:37-79

Boëda É (1991b) La conception trifaciale d'un nouveau mode de taille paléolithique. In: Bonifay E, Vandermeersch B (eds) Les premiers européens. Actes du Congrès National des Sociétés Savantes. 
Commission de Pré-et Protohistoire, vol 114. Comité des Travaux Historiques et Scientifiques, Paris, pp 251-263

Boëda É (2013) Techno-logique \& Technologie. Une Paléo-histoire des objets lithiques tranchants. Préhistoire au Présent. Institut Universitaire de France. Université Paris Ouest Naterre La Défence. @https://rcheo-editions.com, Paris

Boëda É, Mazière G (1989) Eventail des possibilités d'existence de certains faciès du Paléolithique ancien et moyen dans le Pays d'Othe (Aube). In: Boucher A (ed) Pré et protohistoire de l'Aube: exposition présentée au Musée de Nogent-sur-Seine juin - octobre 1989. Édition du Association Régionale pour la Protection et l'Etude du Patrimoine Préhistorique, Vertus, pp 69-73

Bohmers A (1944) Die Mauerner Höhlen und ihre Bedeutung für die Einteilung der Altsteinzeit. In: Jankuhn H (ed) Jahrestagungen. Bericht über die Kieler Tagung 1939. Forschungs- und Lehrgemeinschaft "Das Ahnenerbe". Karl Wachholtz, Neumünster, pp 65-73

Bohmers A (1951) Die Höhlen von Mauern. Teil I. Kulturgeschichte der altsteinzeitlichen Besiedlung. Palaeohistoria 1:3-107

Böhner U (2000) Die Schicht E3 der Sesselfelsgrotte und die Funde aus dem Abri I am Schulerloch Späte Micoquien-Inventare und ihre Stellung zum Moustérien. Doctoral thesis, Friedrich-AlexanderUniversität Erlangen-Nürnberg.

Böhner U (2008) Sesselfelsgrotte IV. Die Schicht E3 der Sesselfelsgrotte und die Funde aus dem Abri I am Schulerloch. Späte MicoquienInventare und ihre Stellung zum Moustérien. Sesselfelsgrotte, vol 4. Franz Steiner Verlag, Stuttgart

Bonč-Osmolovskij G (1929) Le Paléolithique de Crimée. Bulletin de la Commission pour l'étude du Quaternaire 1:27-48

Bordes FH (1953a) Essai de Classification des industries « moustériennes ». BSPF 50:457-466. https://doi.org/10.3406/bspf.1953.5156

Bordes FH (1953b) Le dernier interglaciaire et la place du Micoquien et du Tayacien. L'Anthropologie 57:172-177

Bordes FH (1954) Les limons quaternaires du Basin de la Seine. Stratigraphie et archéologie paléolithique. Mémoire des archives de l'Institut de Paléontologie, vol 26. Masson, Paris

Bordes FH (1961a) Mousterian Cultures in France: Artifacts from recent excavation dispel some popular misconceptions about Neanderthal man. Science 134:803-810. https://doi.org/10.1126/science.134. 3482.803

Bordes FH (1961b) Typologie du Paléolithique ancien et moyen. Publications de l'Institut de préhistoire de l'Université de Bordeaux., vol 1. Delmas, Bordeaux

Bordes FH (1966) Acheulean cultures in southwest France. In: Sen D, Gosh AK (eds) Studies in prehistory. Robert Bruce Foote memorial volume. K. L. Mokhopadhyay, Calcutta, pp 49-57

Bordes FH (1968) Le Paléolithique dans le monde. Collection l'Univers des connaissances. Éditions Hachette, Paris

Bordes FH (1971) Observations sur l'Acheuléen des grottes en Dordogne. Munibe 23:5-23

Bordes FH (1977) Time and space limits of the Mousterian. In: Wright R (ed) Stone tools as cultural markers: change, evolution and complexity, Prehistory and material culture series, vol 12. Humanities Press, New Jersey, pp 37-39

Bordes FH (1981) Vingt - cinq ans après: le complexe moustérien revisité. BSPF 78:77-87. https://doi.org/10.3406/bspf.1981.5336

Bordes FH (1984) Leçons sur le Paléolithique. Le Paléolithique en Europe vol 2. Cahiers du Quaternaire, vol 7. Éditions du CNRS, Paris

Bordes FH, Bourgon M (1951) Le complexe Moustérien: moustériens, levalloisien et tayacien. L'Anthropologie 55:1-23

Bordes FH, Müller-Beck H (1956) Zur Chronologie der Lößsedimente in Nordfrankreich und Süddeutschland. Germania 34:199-208. https:// doi.org/10.11588/ger.1956.43812

Bosinski G (1963) Eine mittelpaläolithische Formengruppe und das Problem ihrer geochronologischen Einordnung. E\&G Eiszeitalter und Gegenwart Quart Sci J 14:124-140. https://doi.org/10.3285/ eg.14.1.14

Bosinski G (1967) Die mittelpaläolithischen Funde im westlichen Mitteleuropa. Fundamenta - Monographien zur Urgeschichte, vol A4. Böhlau, Köln

Bosinski G (1969) Eine Variante der Micoque-Technik am Fundplatz Buhlen, Kreis Waldeck. Jahresschrift mitteldeutscher Vorgeschichte 53:59-74

Bosinski G (1970) Bemerkungen zu der Grabung D. Peyronys in La Micoque. In: Gripp K, Schütrumpf R, Schwabedissen H (eds) Frühe Menschheit und Umwelt. Teil 1 Archäologische Beiträge. Festschrift Alfred Rust. Fundamenta - Monographien zur Urgeschichte, vol A2, 1st. edn. Böhlau, Köln, pp 52-56

Bosinski G (1981) Découvertes récentes de Paléolithique inférieur et moyen en Allemagne du nord-ouest. Notae Praehistoricae 1:100 102

Bosinski G (1982) The Transition Lower/Middle Palaeolithic in northwestern Germany. In: Ronen A (ed) The Transition from Lower to Middle Palaeolithic and the Origins of Modern Man. International symposium to commemorate the 50th anniversary of excavations in the Mount Carmel caves by D.A.E. Garrod. University of Haifa 6-14 October 1980. British archaeological reports international series 151. Archaeopress, Oxford, pp 165-175

Bosinski G (1985) Der Neandertaler und seine Zeit. Kunst und Altertum, vol 118. Dr. Rudolf Habelt GmbH, Bonn.

Bosinski G (2000-2001) El Paleolítico Medio en Europa Central. Zephyrus 53:79-142

Bosinski G (2008) Urgeschichte am Rhein. Tübinger Monographien zur Urgeschichte. Kerns Verlag, Tübingen

Bosinski G, Kulick J (1973) Der mittelpaläolithische Fundplatz Buhlen, Kreis Waldeck. Vorbericht über die Grabungen 1966-69. Germania 51:1-41

Bosinski G et al. (1995) Palaeolithic sites in the Rheinland. In: Schirmer W (ed) Quaternary field trips in Central Europe, vol 2. Verlag Dr. Friedrich Pfeil, München, pp 831-999

Boule M (1915a) M. Hauser et Les Eyzies. L'Anthropologie 26:176-182

Boule M (1915b) Une Marque de Sympathie pour Hauser. L'Anthropologie 26:295

Boule M (1916a) Hauser, docteur de la « Kultur ». L'Anthropologie 27: 497-498

Boule M (1916b) Hauser, ex-membre du T.C.F. L'Anthropologie 27:497

Boule M (1916c) Nouvelles d'Allemagne et d'Hauser. L'Anthropologie 27:303-304

Bourguignon L (1992) Analyse du processus opératoire des coups de tranchet latéraux dans l'industrie moustérienne de l'abri du Musée (Les Eyzies-de-Tayac, Dordogne). Paléo 4:69-89. https://doi.org/ 10.3406/pal.1992.1195

Bourguignon L (1996) La Conception de Débitage Quina. Quaternaria Nova 6:149-166

Brenet M, Folgado M (2003) Le débitage discoïde du gisement des Forets à Saint-Martin-de-Gurçon (Dordogne). In: Peresani M (ed) Discoid lithic technology: advances and implications, British archaeological reports international series, vol 1120. Archaeopress, Oxford, pp $153-178$

Breuil H (1926) Palaeolithic industries from the beginning of the Rissian to the beginning of the Wurmian glaciation. Man 26:176-179. https://doi.org/10.2307/2787959

Breuil H (1930) Premières impressions de voyage sur la préhistoire SudAfricaine. L'Anthropologie 40:209-223

Breuil H (1932a) Le Paléolithique ancien en Europe Occidentale et sa Chronologie. BSPF 29:570-578. https://doi.org/10.3406/bspf.1932. 5670

Breuil H (1932b) Les industries à éclat du Paléolithique ancien: I. Le Clactonien. Préhistoire 1:125-190

Breuil H (1938) The Stone Age of Mount Carmel. Nature 141:304-306. https://doi.org/10.1038/141304a0 
Brézillon MN (1971) La dénomination des objets de pierre taillée: matériaux pour un vocabulaire des préhistoriens de langue française. Gallia Préhistoire Supplément, vol 4. Éditions du CNRS, Paris

Burdo RPC (1951) L'état présent des fouilles à la grotte moustérienne de la Cotte de Saint-Brelade à Jersey. BSPF 48:322-324. https://doi. org/10.3406/bspf.1951.2902

Burdo RPC (1956) Résultats des fouilles récentes (1951-1956) à la grotte de la Cotte de Saint-Brelade à Jersey. BSPF 53:374-380. https://doi. org/10.3406/bspf.1956.3352

Burdo RPC (1960) La Cotte-de-Saint-Brelade, Jersey, British Channel Islands: excavation of a pre-Mousterian horizon, 1950-1958. Société Jersiaise, Jersey

Burdukiewicz JM (2000) The backed biface assemblages of East Central Europe. In: Ronen A, Weinstein-Euron M (eds) Toward modern humans: the Yabrudian and the Micoquian 400-50 k-years ago. Proceedings of a Congress held at the University of Haïfa November 3-9, 1996. British archaeological reports international series 850. Archaeopress, Oxford, pp 155-165

Cahen D, Haesaerts P (1984) Peuples Chasseurs de la Belgique préhistorique dans leur cadre naturel. Institut Royal des Sciences Naturelles de Belgique, Bruxelles

Cahen D, Michel J (1986) Le site paléolithique moyen ancien de Mesvin IV (Hainaut Belgique). In: Tuffreau A, Sommé J (eds) Chronostratigraphie et faciès culturels du paléolithique inférieur et moyen dans l'Europe du nord-ouest: actes du Colloque international organisé à l'Université des sciences et techniques de Lille dans le cadre du 22e Congrès préhistorique de France (Lille-Mons, 2-7 septembre 1984). Supplément au Bulletin de l'Association française pour l'étude du quaternaire, vol 26. Association française pour l'étude du quaternaire, Paris, pp. 89-102

Cahen D, Haesaerts P, Szabo BJ, Van Neer W, Wanet P (1984) An Early Middle Palaeolithic site at Mesvin IV (Mons, Belgium). Its significance for stratigraphy and Paleontology. Bull Inst R Sci Nat Belg 55: $1-20$

Callow P, Cornford JM (1986) La Cotte de St. Brelade, 1961-1978: excavations by C.B.M. McBurney. Geo Books, Norwich

Campy M, Chaline J, Vuillemey M (1989) La Baume de Gigny (Jura). Supplément à Gallia Préhistoire vol 27. Éditions du CNRS, Paris

Capitan L (1896a) La station acheuléenne de La Micoque (Dordogne). Bulletins de la Société d'anthropologie de Paris 7:529-532. https:// doi.org/10.3406/bmsap.1896.5664

Capitan L (1896b) La station acheuléenne de la Micoque (Dordogne). Revue mensuelle de l'École d'Anthropologie de Paris 16:406-416

Çep B (2014) Das mittelpaläolithische Silexinventar des Bocksteins im Lonetal (Schwäbische Alb). Vielfalt der Formen oder Fortbestand einer technologischen Idee? In: Beier H-J, Einicke R, Biermann E (eds) "Material-Werkzeug: Werkzeug-Material" \& "Klinge, Messer, Schwert \& Co - Neues aus der Schneidenwelt" Aktuelles aus der Neolithforschung. Beiträge der Tagungen der Arbeitsgemeinschaft Werkzeuge und Waffen Pottenstein (Fränkische Schweiz) 2011 \& Herxheim bei Landau in der Pfalz 2012 sowie Aktuelles. Beiträge zu Ur- und Frühgeschichte Mitteleuropas, vol 75. Beier \& Beran, Langenweissbach, pp 79-92

Çep B (2019) Das Mittelpaläolithikum auf der Schwäbischen Alb. In: Baales M, Pasda C (eds) ,All der holden Hügel ist keiner mir fremd ..." Festschrift zum 65. Geburtstag von Claus-Joachim Kind. Universitätsforschungen zur prähistorischen Archäologie 327. Verlag Dr. Rudolf Habelt, Bonn, pp 99-107

Çep B, Krönneck P (2015) Landscape and cave use in the Middle Paleolithic of Bockstein: new results from the lithic and fauna analysis. In: Conard NJ, Delagnes A (eds) Settlement dynamics of the Middle Paleolithic and Middle Stone Age, Tübingen publications in prehistory, vol IV. Kerns Verlag, Tübingen, pp 227-251

Chauvet G (1896) Station quaternaire de La Micoque. Bulletin de la Société Archéologique et Historique de la Charente 16:92-98
Chauvet G, Rivière E (1896) La Micoque. Rev Sci 33:284-285

Chauvet G, Rivière E (1898) Station quaternaire de La Micoque (Dordogne). In: Masson G, Masson C (eds) Compte Rendu de la 26e Session, Saint-Étienne 1897, vol 2. Association Française pour l'Avancement des Sciences, Saint-Germain, pp 697-708

Chmielewski W (1969) Ensembles micoquo-prondnikiens en Europe centrale. Geogr Pol 17:371-386

Chmielewski W (1970) The Micoquian-Proudnik group of assemblages in Central Europe. In: Filip J (ed) Actes du VIIe Congrès International des Sciences Préhistoriques et Protohistoriques, Prague, 21-27 Août 1966, vol 1. Institut d'Archéologie de l'Académie Tchécoslovaque des Science à Prague, Prague, pp 311-312

Chmielewski W (1972) The continuity and discontinuity of the evolution of archaeological cultures in central and eastern Europe between the 55th and 25th millenaries B.C. In: Bordes F (ed) The origin of Homo sapiens, Proceedings of the Paris symposium, 2-5 September, vol 1969. United Nations Educational, Scientific and Cultural Organization, Paris, pp 173-179

Chmielewski W (1975) The Upper Pleistocene archeological site Zwierzyniec I in Cracow. Swiatowit 34:7-59

Clark JD (1966) Acheulian occupation sites in the Middle East and Africa: a study in cultural variability. Am Anthropol 68:202-229. https://doi.org/10.1525/aa.1966.68.2.02a001010

Clark JD, Cole GH, Isaac GL, Kleindienst MR (1966) Precision and definition in African archaeology. S Afr Archaeol Bull 21:114 121. https://doi.org/10.2307/3888427

Clarke DL (1968) Analytical archaeology. Methuen, London

Cliquet D, Monnier JL (1993) Signification et évolution du Paléolithique moyen récent armoricain. BSPF 90:275-282. https://doi.org/10. 3406/bspf.1993.9594

Collins D (1969) Culture traditions and environment of early man. Pleistocene cultural evolution with special reference to the stone technology of northwestern Europe before the Last Glaciation. Curr Anthropol 10:267-316

Combier J (1965) Circumscription de Lyon. GalliaPrHist:103-127

Combier J, Thévenot J-P (1976) Livret-Guide de l'Éxcursion A8. Bassin du Rhône. Paléolithique et Néolithique. IXe Congrès de Union international des Sciences Préhistorique et Protohistoriques. Union international des Sciences Préhistorique et Protohistoriques, Nice

Conard NJ (2011) The demise of the Neanderthal cultural niche and the beginning of the Upper Paleolithic in southwestern Germany. In: Conard NJ, Richter J (eds) Neanderthal lifeways, subsistence and technology: one hundred fifty years of Neanderthal study. Proceedings of the international congress to commemorate " 150 years of Neanderthal discoveries, 1856-2006", organized by Silvana Condemi, Wighart von Koenigswald, Thomas Litt and Friedemann Schrenk, held at Bonn, 2006, Volume II. Vertebrate Paleobiology and Paleoanthropology Series. Springer, Dortrecht, pp. 223-240. https://doi.org/10.1007/978-94-007-0415-2_19

Conard NJ, Fischer B (2000) Are there recognizable cultural entities in the German Middle Palaeolithic? In: Ronen A, Weinstein-Evron M (eds) Toward modern humans: The Yabrudian and the Micoquian 400-50 k-years ago. Proceedings of a Congress held at the University of Haïfa November 3-9, 1996, British archaeological reports international series, vol 850. Archaeopress, Oxford, pp 7-21

Cro-Magnon H (1915) La guerre et M Hauser. L'Anthropologie 26:169171

Daniel R (1965) Les stations moustériennes des environs de Saint-Juliende-la-Liègue (Eure). BSPF 61:22-30. https://doi.org/10.3406/bspf. 1965.4009

Daniel M, Daniel R, Degros J, Vinot A (1973) Les gisements préhistoriques du Bois de Verrières-le-Buisson (Essonne). I Le site paléolithique du Terrier. GalliaPrHist 16:63-103. https://doi.org/10. 3406/galip.1973.1438 
Delagnes A (1993) Un mode de production inédit au Paléolithique moyen dans l'industrie du niveau 6e du Pucheuil (Seine-Maritime). Paléo 5: $111-120$

Delagnes A (2000) Blade production during the Middle Paleolithic in northwestern Europe. In: Dong W (ed) Proceedings of the 1999 Beijing International Symposium on Paleoanthropology. In Commemoration of the 70th anniversary of the discovery of the first skull-cap of the Peking Man. Supplement to Acra Anthropologica Sinica 19. Institute of Vertebrate Paleonology and Paleoanthropology, Beijing, pp 181-188

Delagnes A, Rendu W (2011) Shifts in Neandertal mobility, technology and subsistence strategies in western France. JAS 38:1771-1783. https://doi.org/10.1016/j.jas.2011.04.007

Delagnes A, Jaubert J, Meignen L (2007) Les technocomplexes du Paléolithique moyen en Europe occidentale dans leur cadre diachronique et géographique. In: Vandermeersch B, Maureille B (eds) Les néandertaliens: biologie et cultures, Documents préhistoriques vol, vol 23. Comité des Travaux Historiques et Scientifiques, Paris, pp 213-229

Deloze V, Depaepe P, Gouédo J-M, Krier V, Locht J-L (1994) Le Paleolithique dans le Nord du Senonais (Yonne): Contexte Geomorphologique, Industries Lithiques et Chronostratigraphie. Documents d'archeologie Française, vol 47. Maison des Sciences de l'Homme, Paris

Depaepe P (2002) Le Paléolithique moyen de la vallée de la Vanne (Yonne). Matières premières, indistries lithiques et occupations humanines. Doctoral thesis, Université des Science et Technologies de Lille, Université de Lille I

Depaepe P (2014) European Middle Paleolithic: geography and culture. In: Smith C (ed) Encyclopedia of global archaeology. Springer, New York, pp 2645-2670

Desbrosse R, Tavoso A (1970) Un gisement moustérien à Blanzy (Saône et Loire). Quartär 21:21-45. https://doi.org/10.7485/QU21_02

Desbrosse R, Texier P-J (1973a) La station moustérienne de Bissy-surFley (S.-\&-L.). La Physiophile 79:8-31

Desbrosse R, Texier P-J (1973b) Les silex de Germolles dans la collection Jeannin. La Physiophile 79:64-69

Desbrosse R, Kozłowski JK, Zuate y Zuber J (1976) Prondniks de la France et d'Europe centrale. L'Anthropologie 80:431-488

Despriée J, Lorain J (1982) Les industries du Paléolithique inférieur et moyen de la vallée du Loir Vendômois dans leur contexte géologique. Quaternaire 19:113-122. https://doi.org/10.3406/ quate.1982.1427

Esin U, Benedict P (1963) Recent developments in the prehistory of Anatolia. Curr Anthropol 4:339-346

Farizy C (1995) Industries Charentiennes à Influences Micoquiennes, l'Exemple de 1'Est de la France. Paléo Supplément:173-178. https://doi.org/10.3406/pal.1995.1393

Feustel R (1983) Die früheste Entwicklung der Produktivkräfte. AltThüringen 19:7-15

Fiedler L (1977) Altsteinzeitliche Fundplätze in Hessen. Führer zur hessischen Vor- und Frühgeschichte, vol 2. Landesamt für Denkmalpflege Hessen, Wiesbaden

Freericks M (1995) Transition du Paléolithique moyen au Paléolithique supérieur en Allemagne: quelques exemples. Paléo Supplément: 117-122. https://doi.org/10.3406/pal.1995.1388

Freund G (1963) Die ältere und mittlere Steinzeit in Bayern. Jahresbericht der Bayerischen Bodendenkmalpflege 4:9-166

Frick JA (2016) On technological and spatial patterns of lithic objects. Evidence from the Middle Paleolithic at Grotte de la Verpillière II, Germolles, France. Doctoral thesis, Eberhard Karls Universität Tübingen. https://doi.org/10.15496/publikation-14816

Frick JA, Herkert K (2014) Lithic technology and logic of technicity. Mitteilungen der Gesellschaft für Urgeschichte 23:129-172

Frick JA, Herkert K, Hoyer CT, Floss H (2017) The performance of tranchet blows at the Late Middle Paleolithic site of Grotte de la
Verpillière I (Saône-et-Loire, France). PLoS ONE 12:1-44. https:// doi.org/10.1371/journal.pone.0188990

Gábori M (1976) Les civilisations du Paleolithique moyen entre les Alpes et l'Oural. Esquisse historique. Akadémiai Kiadó, Budapest

Garrod DAE (1962) The Middle Palaeolithic of the Near East and the problem of Mount Carmel man. J R Anthropol Inst G B Irel 92:232259

Garrod DAE, Bate DMA, McCown TD, Keith A (1937) The Stone Age of Mount Carmel. Joint expedition of the British School of Archaeology in Jerusalem and the American School of Prehistoric Research (1929-1934) vol 1. Oxford University Press, Oxford

Giot PR (1962-1963) Problemes de Geologie Quaternaire en Bretagne. Quartär 14:1-14

Golomshtok EA (1938) The Old Stone Age in European Russia. TAPS 29:190-460. https://doi.org/10.2307/1005529

Gouedo JM (1988) Etude préliminaire de la technologie de l'industrie de Champlost: exemples de la chaîne opératoire Levallois et des racloirs à retouche biface. Revue archéologique de Picardie 1:149 155

Gouédo J-M (1999) Le technocomplexe micoquien en Europe de l'ouest et centrale: exemples de trois gisements du sud-est du basin parisien, Vinneuf et Champlost (Yonne), Verrières-le-Buisson (Essonne). Doctoral thesis, Université des Sciences et Technologies de Lille 1

Gouédo J-M, Alix P, Beaune SAd, Krier V, Locht J-L (1994) Études archéologiques: Vinneuf/Les Hauts Massous (plateau du Sénonais). In: Deloze V, Depaepe P, Gouédo J-M, Krier V, Locht J-L (eds) Le Paléolithique moyen dans le nord du Sénonais (Yonne). Maison des sciences de l'Homme, Paris, pp. 83-118.

Grahmann R (1940) Andree, Julius. Der eiszeitliche Mensch in Deutschland und seine Kulturen. Geogr Z 46:188-189

Grahmann R (1952) Urgeschichte der Menschheit. Einführung in die Abstammungs- und Kulturgeschichte der Menschheit, 1st edn. W. Kohlhammer Verlag, Stuttgart

Grahmann R, Müller-Beck H (1967) Urgeschichte der Menschheit, 3rd edn. W. Kohlhammer Verlag, Stuttgart

Grenier A (1945) Compte rendu d'une note de l'abbé Breuil sur ses recherches sur le paléolithique sud-africain. Comptes rendus des séances de l'Académie des Inscriptions et Belles-Lettres 89:51-55. https://doi.org/10.3406/crai.1945.77821

Gross H (1962-1963) Der gegenwärtige Stand der Geochronologie des Spätpleistozäns in Mittel- und Westeuropa. Quartär 14:49-68

Guillaume C (1982) Les gisements du Paléolithique inférieur et moyen de Lorraine. Bulletin de l'Association Française pour l'Étude du Quaternaire 19:135-146. https://doi.org/10.3406/quate.1982.1431

Günther G (1962) Neue Ausgrabungen in der Balver Höhle. PZ 40:271272. https://doi.org/10.1515/prhz.1962.40.1-2.269

Günther K (1964) Die alsteinzeitlichen Funde der Balver Höhle. Mit Beiträgen von Bernhard Bahnschulte und Florian Heller. Bodenaltertümer Westfalens, vol 8. Aschendorffsche Verlagsbuchhandlung, Münster

Hauser O (1915) Letter of Otto Hauser to Berliner Gesellschaft für Anthropologie, Ethnologie und Urgeschichte. ZfE 47:443-444

Hauser O (1916) Über eine neue Chronologie des mittleren Paläolithikums im Vézèretal: Speziell mit bezug auf meine Ausgrabungen auf la Micoque. Doctoral thesis, FriedrichAlexanders-Universität zu Erlangen

Hauser O (1928) Die große zentraleuropäische Urrasse: La Micoque Ehringsdorf - Byci skála - Predmost - Kisla Nedzimova. Ein Beitrag zur Entstehung der Weißen Rasse. Verlag für Urgeschichte und Menschforschung, Weimar

Hérisson D et al (2016) The emergence of the Middle Palaeolithic in north-western Europe and its southern fringes. Quat Int 411:233283. https://doi.org/10.1016/j.quaint.2016.02.049

Hörmann K (1916) Sitzung der Anthropologischen Sektion der Naturhistorischen Gesellschaft Nürnberg. Korrespondenz-Blatt der 
Deutschen Gesellschaft für Anthropologie, Ethnologie und Urgeschichte 47:30-31

Janot A (1981) Essai de chronologie des industries paléolithiques à quartzites de la région sud de Nancy (Meurthe-et-Moselle). BSPF 78:306-316. https://doi.org/10.3406/bspf.1981.5284

Jaubert J (2011) Les archéo-séquences du Paléolithique moyen du SudOuest de la France: Quel bilan un quart de siècle après François Bordes? In: Delpech F, Jaubert J (eds) François Bordes et la Préhistoire Colloque International François Bordes, Bordeaux, 2224 Avril 2009. Éditions du Comité des travaux historiques et scientifiques, Bordeaux, pp 235-253

Jaubert J (2014) Middle Palaeolithic archeo-sequences from southwestern France: where do we stand a quarter century after François Bordes? In: Derevianko AP, Drozdov NI (eds) Topical issues of the Asian Paleolithic. Proceedings of the international symposium in Krasnoyarsk, July 6-12, 2012. Institute of Archaeology and Ethnography Press, Novosibirsk, pp 44-62

Jöris O (1992) Pradniktechnik im Micoquien der Balver Höhle. Archäologisches Korrespondenzblatt 22:1-12

Jöris O (1993) Die Pradniktechnik in Buhlen (Oberer Fundplatz). Eine technologische Studie anhand ausgewählter Beispiele. Magister's thesis, University of Köln

Jöris O (2003) Zur chronostratigraphischen Stellung der spätmittelpaläolithischen Keilmessergruppen: Der Versuch einer kulturgeographischen Abgrenzung einer mittelpaläolithischen Formengruppe in ihrem europäischen Kontext. BerRGK 84:49-153

Joullié H (1963) Bifaces micoquiens et lancéolés de la vallée de l'Aisne aux environs de Vailly-sur-Aisne. Bulletin de la Société Archéologique Champenoise 56:10-17

Kind C-J (1992) Bemerkungen zur Differenzierung des süddeutschen Mittelpaläolithikums. Archäologisches Korrespondenzblatt 22: $151-159$

Koehler H (2009) Comportements et identité techniques au Paléolithique moyen (Weichsélien ancien) dans le Bassin parisien: une question d'échelle d'analyse? Doctoral thesis, Université Paris X-Nanterre la Défense

Koenigswald WV, Müller-Beck H (1975) Das Pleistozän der Weinberghöhlen bei Mauern (Bayern). Quartär 26:107-118. https://doi.org/10.7485/QU26 06

Koenigswald Wv, Müller-Beck H, Pressmar E (1974) Die Archäologie und Paläontologie in den Weinberghöhlen bei Mauern (Bayern): Grabungen 1937-1967 vol 3. Institut für Urgeschichte

Kolosov YG (1986) Akkajskaya Musterskaya Kultura. Naukova Dumka, Kiew

Kowalski S (1967) Ciekwsze zabytki paleolityczne z najnowszych badan' archeologicznych (1963-1965) w Jaskini Ciemnej w Ojcowie, pow. Olkusz. Mater Archeol 8:39-44

Kozłowski L (1924) Die ältere Steinzeit in Polen. Die Eiszeit Zeitschrift für allgemeine Eiszeitforschung 1:112-163

Kozłowski JK (1961) Bemerkungen über den Stand der Paläolithforschung in Polen. ArchAustr 30:118-143

Kozłowski JK (1972) Comment on Bosinki (1972) Late Middle Palaeolithic groups in north-western Germany and their relations to early Upper Palaeolithic industries. In: Bordes F (ed) The origin of Homo sapiens. Proceedings of the Paris symposium, 2-5 September 1969, organized by UNESCO in co-operation with the International Union for Quaternary Research (INQUA). Unesco, Paris, pp 160-160

Kozłowski JK (1989) La fin du paléolithique moyen en Pologne. Anthropologie (Brno) 27:133-142

Kozłowski JK (2014) Middle Palaeolithic variability in Central Europe: Mousterian vs Micoquian. Quat Int 326-327:344-363. https://doi. org/10.1016/j.quaint.2013.08.020

Kozłowski JK (2016) Taxonomy of the Early Middle Palaeolithic in Central Europe. Litikum 4:19-27. https://doi.org/10.23898/ litikuma0016
Kozłowski JK, Kozłowski SK (1977) Epoka kamienia na ziemiach Polskich. Państwowe Wydawnictwo Naukowe, Warszawa

Krönneck P (2012) Die pleistozäne Makrofauna des Bocksteins (Lonetal - Schwäbische Alb). Ein neuer Ansatz zur Rekonstruktion der Paläoumwelt. Doctoral thesis, Eberhard Karls Universität Tübingen

Krüger H (1964-1965) Zwei Blattspitzen unterschiedlicher Morphologie aus dem Paläolithikum Oberhessens. Quartär 15-16:155-166

Krukowski S (1939-1948) Paleolit. In: Krukowski S, Kostrezewski RJ (eds) Prehistoria ziem polskich. Encyklopedia Polska, vol 4. Drukarnia Uniwersytetu Jagiellonskiego, Kracow, pp 1-117

Laville H (1982) On the transition from "Lower" to "Middle" Palaeolithic in south-west France. In: Ronen A (ed) The transition from Lower to Middle Palaeolithic and the origins of modern man. International symposium to commemorate the 50th anniversary of excavations in the Mount Carmel caves by D.A.E. Garrod. University of Haifa 6-14 October 1980. British archaeological reports international series 151. Archaeopress, Oxford, pp 131-135

Leclercq X, Briois F (1982) Une station du Paléolithique inférieur près de Pamiers, à Fontvives (Ariège). BSPF 79:305-318. https://doi.org/ 10.3406/bspf.1982.5339

Locht J-L et al (2016) Timescales, space and culture during the Middle Palaeolithic in northwestern France. Quat Int 411:129-148. https:// doi.org/10.1016/j.quaint.2015.07.053

Lumley H (1960) Clactonien et Tayacien dans la région méditerranéenne française. C R Seances Acad Sci 250:1887-1888

Lumley H (ed) (1976) Le Civilisations Paléolithiques et Mésolithiques de la France. La Préhistoire Française, vol 1, 1st. edn. Éditions du CNRS, Paris

Luttropp A, Bosinski G (1971) Der Altsteinzeitliche Fundplatz Reutersruh bei Ziegenhain in Hessen. Fundamenta Monographien zur Urgeschichte, vol A6. Böhlau-Verlag, Köln

Mania D (1990) Auf den Spuren des Urmenschen: Die Funde aus der Steinrinne von Bilzingsleben. Deutscher Verlag der Wissenschaften, Berlin

Mania D, Toepfer V (1973) Königsaue: Gliederung, Ökologie und mittelpaläolithische Funde der letzten Eiszeit. Veröffentlichungen des Landesmuseums für Vorgeschichte in Halle, vol 26. Deutscher Verlag der Wissenschaften, Berlin

McBurney CMB (1950) The geographical study of the Older Palaeolithic stages in Europe. PPS 16:163-183. https://doi.org/10.1017/ S0079497X00019009

McCarthy I (1995) Manufacturing classification: lessons from organizational systematics and biological taxonomy. Integr Manuf Syst 6: 37-48. https://doi.org/10.1108/09576069510099365

Mellars PA (1996) The Neanderthal legacy. An archaeological perspective of western Europe. Princeton University Press, Princeton

Menghin O (1926) Zur Terminologie des Paläolithikums. WPZ 13:1-13

Menghin O (1931) Weltgeschichte der Steinzeit. Anton Scholl \& Co., Wien

Molines N, Hinguant S, Monnier J-L (2001) Le Paléolithique moyen à outils bifaciaux dans l'Ouest de la France: synthèse des données anciennes et récentes. In: Cliquet D (ed) Les Industries à Outils Bifaciaux du Paléolithique Moyen d'Europe Occidentale. Actes de la table ronde organisée à Caen (Basse-Normandie - France). 14 et 15 octobre 1999. Études et Recherches Archéologiques de l'Université de Liège, vol 98. Université de Liège, Liège, pp 109115

Monnier JL (1986) Chronostratigraphie et faciès cultureles du Paléolithique inférieur et moyen en Bretagne. Comparaison avec les régions loessiques. In: Tuffreau A, Sommé J (eds) Chronostratigraphie et faciès culturels du paléolithique inférieur et moyen dans l'Europe du nord-ouest: actes du Colloque international organisé à l'Université des sciences et techniques de Lille dans le cadre du 22e Congrès préhistorique de France (Lille-Mons, 2-7 septembre 1984). Supplément au Bulletin de Association française 
pour l'étude du quaternaire, vol 26. Association française pour l'étude du quaternaire, Paris, pp 113-127

Monnier J-L (1988) Chronostratigraphie et écologie des industries paléolithiques de la Bretagne. Revue archéologique de Picardie 12:75-80. https://doi.org/10.3406/pica.1988.1578

Mortillet Gd (1869) Essai d'une classification des cavernes et des stations sous abri fondée sur les produits de l'industrie humaine. In: Mortillet GD (ed) Matériaux pour L'histoire primitive et naturelle de L'Homme et l'étude du sol, de la faune et de la flore qui s'y rattachent, vol 5. Reinwald, Paris, pp. 172-179.

Mortillet Gd (1873) Classification des diverses périodes de l'âge de la pierre. In: Mortillet GD (ed) Compte Rendu du Congrès International d'Anthropologie et d'Archéologie Préhistorique. 6ième Session, Bruxelles, 1872. Weissenbruch, Paris, pp 432-444

Mortillet G (1883) Le préhistorique. Antiquité de l'homme vol 8. Bibliothèque des Sciences Contemporaines. Ch. Ferdinand Reinwald, Paris

Mortillet A (1907) Présentation d'une carte topographique de Otto Hauser. Bulletin de la Société Préhistorique de France 4:500-501. https://doi.org/10.3406/bspf.1907.7835

Müller-Beck H (1956) Das obere Altpaläolithikum in Süddeutschland. Ein Versuch zur ältesten Geschichte des Menschen, vol 1. Hamburger Buchdruckerei und Verlagsanstalt Auerdruck, Hamburg

Müller-Beck H (1957) Paläolithische Kulturen und Pleistozäne Stratigraphie in Süddeutschland. E\&G Eiszeitalter und Gegenwart Quart Sci J 8:116-140. https://doi.org/10.3285/eg.08.1.07

Müller-Beck H (1958) Zur Bezeichnung paläolithischer Artefakttypen. Alt-Thüringen 3:140-200

Müller-Beck H (1966) Paleohunters in America: origins and diffusion. Science 152:1191-1210. https://doi.org/10.1126/science.152.3726. 1191

Narr KJ (1953) Zur Frage altpaläolithischer Kulturkreise. Anthropos 48: 773-794

Obermaier H (1908a) Die Steingeräte des französischen Altpaläolithikums: Eine kritische Studie über ihre Stratigraphie und Evolution. Mittheilungen der Prähistorischen Commission der Kaiserlichen Akademie der Wissenschaften, vol 1-2. A. Hölder, Wien

Obermaier H (1908b) M. Hauser et la Micoque. RÉA 10:85-88. https:// doi.org/10.3406/rea.1908.1532

Obermaier H (1912) Der Mensch der Vorzeit. Der Mensch aller Zeiten. Natur und Kultur der Völker der Erde, vol 1. Allgemeine Verlagsgesellschaft, Berlin

Obermaier H (1924) Acheuléen. In: Ebert M (ed) Erster Band. Aal Beschneidung, Reallexikon der Vorgeschichte, vol 1. Verlag Walter de Gruyter \& Co., Berlin, pp 8-10

Penck AFK, Brückner E (1909) Die Alpen im Eiszeitalter. Tauchnitz, Leipzig

Peyrony D (1908) A propos des fouilles de La Micoque et des travaux récents parus sur ce gisement. Revue de l'École d'Anthropologie de Paris 11:380-382

Peyrony D (1921) Le Moustérien - Ses faciès. In: Calmétie A (ed) Compte Rendu de la 44ème Session de la Association Française pour l'Avancement des Sciences, Strasbourg 1920. Masson, Paris, pp 496-497

Peyrony D (1930) Le Gisement préhistorique de la Micoque et ses nouvelles industries. In: Perrier G (ed) Compte Rendu de la 53e Session. Accociation Française pour l'Avancement des Sciences. Le Havre 1929. Accociation Française pour l'avancement des Sciences, Paris, pp 487-488

Peyrony D (1933) La Micoque et ses diverses industries. In: XVe Congrès International d'Anthropologie et d'Archéologie Préhistorique. Ve session de l'Institut international d'anthropologie: Paris, 20-27 septembre 1931. E. Nourry, Paris, pp 1-6

Peyrony D (1938) La Micoque. Les Fouilles récentes.-Leur signification. BSPF 35:257-283. https://doi.org/10.3406/bspf.1938.12316
Pittioni R (1939) Andree Julius. Der eiszeitliche Mensch in Deutschland und seine Kulturen. Anthropos Stud Anthropol Palaeoethnol Palaeontol Quat Geol 34:451-452

Prausnitz MW (1969) The sequence of Early to Middle Paleolithic flint industries along the Galilean littoral. IEJ 19:129-136

Richter J (1997) Sesselfelsgrotte III. Der G-Schichten-Komplex der Sesselfelsgrotte. Zum Verständnis des Micoquien. QuartärBibliothek, vol 7. Saarbrückener Druckerei und Verlag, Saarbrücken

Richter J (2002) Die ${ }^{14}$ C-Daten aus der Sesselfelsgrotte und die Zeitstellung des Micoquien/M.M.O. Germania 80:1-22

Richter J (2006) Neanderthals in their landscape. In: Demarsin B, Otte M (eds) Neanderthals in Europe. Actes de la conférence internationale, au Musée gallo-romain de Tongres, 17-19 septembre 2004. Études et Recherches Archéologiques de l'Université de Liège, vol 117. Université de Liège, Liège, pp 51-66

Richter J (2014) L'impact environnemental sur la formation des assemblages lithiques unifaciaux et bifaciaux « micoquiens » ou « $\mathrm{MMO}$ » d'Europe centrale. In: Jaubert J, Fourment N, Depaepe P (eds) Paléolithique et Mésolithique. Transitions, ruptures et continuité en Préhistoire. Transitions, rupture and continuity in prehistory. XXVIIe Congrès préhistorique de France. Bordeaux - Les Eyzies, 31 mai-5 juin 2010), vol 2. Société Préhistorique Française, Paris, pp 195-205

Richter J (2016) Leave at the height of the party: a critical review of the Middle Paleolithic in Western Central Europe from its beginnings to its rapid decline. Quat Int 411:107-128

Richter J (2018) Altsteinzeit: Der Weg der frühen Menschen von Afrika bis in die Mitte Europas. Verlag W. Kohlhammer, Stuttgart

Riek G (1934) Die Eiszeitjägerstation am Vogelherd im Lonetal: Die Kulturen. Akademische Verlagsbuchhandlung Franz F. Heine, Tübingen

Rigaud J-P (1986) Circonscription d'Aquitaine. GalliaPrHist 29:233-258

Rigaud J-P (ed) (1988) La Grotte Vaufrey. paléoenvironnement, chronologie, activités humaines. Mémoire de la Sociéte Préhistorique Française, vol 19. Société Préhistorique Française, Châlons-sur-Marne

Ringer Á (1983) Bábonyien. Eine mittelpaläolithische Blattwerkzeugindustrie in Nordostungarn. Doctoral thesis, Eötvös Loránd University

Ronen A, Weinstein-Evron M (2000) Toward modern humans. The Yabrudian and Micoquian. 400-50 k-years ago. Proceedings of a Congress held at the University of Haifa, November 3-9, 1996. British archaeological reports international series, vol 850 . Archaeopress, Oxford

Rosendahl G (1999) La Micoque und das Micoquien in den altsteinzeitlichen Sammlungen des Reiss-Museums Mannheim. Mannheimer Geschichtsblätter Neue Folge 6:315-351

Rosendahl G (2004) Die oberen Schichten von La Micoque (Dordogne, Frankreich). Doctoral thesis, Universität zu Köln

Rosendahl G (2006) Les Couches Supérieures de la Micoque (Dordogne). Paléo:161-192

Rosendahl G (2011) Technological analysis of the bifacial tools from La Micoque and its implications. In: Conard NJ, Richter J (eds) Neanderthal lifeways. Subsistence and technology. One hundred fifty years of Neanderthal study, Vertebrate paleobiology and paleoanthropological series. Springer, New York, pp 133-138

Sacchi C, Chantret F, Klimek É, Vandermeersch B, Vinot A (1978) Les Gisements Préhistoriques du Bois de Verrières-Le-Buisson (Essonne). III. Le Site Paléolithique du Terrier. GalliaPrHist 21: 47-89. https://doi.org/10.3406/galip.1978.1583

Schild R, Wendorf F (1977) The prehistory of Dakhla Oasis and Adjacent Desert. Ossolineum, Wroclaw

Schmidt RR (1911) Die Grundlagen für die Diliuvialchronologie und Paläethnologie Westeuropas. ZfE 43:945-974

Schmidt RR (1912a) Archäologischer Teil. Die Diluvialen Kulturen Deutschlands. In: Schmidt RR (ed) Die diluviale Vorzeit 
Deutschlands. Schweizerbartsche Verlagsbuchhandlung. Nägele und Dr. Sproesser, Stuttgart, pp 1-156

Schmidt RR (ed) (1912b) Die diluviale Vorzeit Deutschlands. Schweizerbartsche Verlagsbuchhandlung. Nägele und Dr. Sproesser, Stuttgart

Schönweiß W (1962-1963) Paläolithische Funde vom Hahnenberg im schwäbisch-bayrischen Ries. Quartär 14:95-104

Schwabedissen H (1973) E. Archaeological research: 1. Palaeolithic and Mesolithic periods. Eiszeit Gegenw 23-24:340-359. https://doi.org/ 10.23689/fidgeo- 1565

Slimak L (2004) Les dernières expressions du Moustérien entre Loire et Rhône. Doctoral thesis, Université de Provence

Sollas WJ (1911) Ancient hunters and their modern representatives, 1st. edn. MacMillian and Co., London

Soriano S (2000) Outillage bifacial et outillage sur éclat au Paléolithique ancien et moyen: coexistence et interaction. Doctoral thesis, Paris X Nanterre-La Defense

Soriano S (2001) Statut fonctionnel de l'outillage bifacial dans les industries du Paléolithique moyen: Propositions méthodologiques. In: Cliquet D (ed) Les industries à outils bifaciuaux du Paléolithique moyen d'Europe occidentale. Actes de la table-ronde internationale organisée à Caen (Basse-Normandie - France) - 14 et 15 octobre 1999. Etudes et recherches archéologiques de l'Université de Liège, vol 98. Liège, pp 77-83

Street M, Baales M, Jöris O (1999) Beiträge zur Chronologie archäologischer Fundstellen des letzten Glazials im nördlichen Rheinland. Terrestrische Quartärgeologie 1999:426-465

Tixier J, Inizan M-L, Roche H (1980) Terminologie et Technologie vol 1. Préhistoire de la Pierre Taillée, vol 47. Cercle de Recherche et d'Études de Prehistoriques, Valbonne

Tuffreau A (1979) Les débuts du Paléolithique moyen dans la France septentrionale. BSPF:140-142. https://doi.org/10.3406/bspf.1979. 5196

Tuffreau A (1982) The transition Lower/Middle Palaeolithic in northern France. In: Ronen A (ed) The transition from Lower to Middle Palaeolithic and the origins of modern man. International symposium to commemorate the 50th anniversary of excavations in the Mount Carmel caves by D.A.E. Garrod: University of Haifa 6-14 October 1980. British archaeological reports international series 151. Archaeopress, Oxford, pp 137-150

Tuffreau A (1988) Les habitats du Paléolithique inférieur et moyen dans le Nord de la France (Nord, Pas-de-Calais, Somme). Revue archéologique de Picardie 1-2:91-104. https://doi.org/10.3406/ pica. 1988.1580

Tuffreau A, Sommé J (eds) (1988) Le Gisement Paléolithique moyen de Biache-Saint-Vaast (Pas-de-Calais). Volume I. Stratigraphie, Environnement, Études Archéologiques (1ère partie). Mémoire de la Société Préhistorique Française, vol 21, 1st. edn. Éditions du Éditions du CNRS, Paris

Ulrix-Closset M (1969-1970) Biface micoquien provenant de la sablière Stouvenakers à Omal (Province de Liège). Bulletin des Chercheurs de la Wallonie 21:307-311

Ulrix-Closset M (1975) Le Paléolithique moyen dans le Bassin mosan en Belgique. Bibliothèque de la Faculté de philosophie et lettres de l'Université de Liège. Publications exceptionnelles, vol 3. Éditions Universa, Wetteren

Urbanowski M (2003) Pradnik knives as an element of Micoqian technostylistic specifics. Doctoral thesis, Warswa University

Uthmeier T (2004) Micoquien, Aurignacien und Gravettien in Bayern: Eine regionale Studie zum Übergang vom Mittel-zum Jungpaläolithikum. Dr. Rudolf Habelt Verlag

Valoch K (1955) Beitrag zur Frage der Blattspitzen im Paläolithikum Mährens. Germania 33:10-12. https://doi.org/10.11588/ger.1955. 43622

Valoch K (1967) Le Paléolithique moyen en Tchécoslovaquie. L'Anthropologie 71:135-144
Valoch K (1968) Evolution of the Palaeolithic in Central and Eastern Europe. CurrAnthr 9:351-390

Valoch K (1988) Die Erforschung der Kůlna-Höhle 1961-1976. Anthropos Studien zur Anthropologie, Paläoethnologie, Paläanthropologie und Quartärgeologie, vol 24. Moravské Muzeum, Brno

Veil S et al (1994) Ein mittelpaläolithischer Fundplatz aus der WeichselKaltzeit bei Lichtenberg, Lkr. Lüchow-Dannenberg. Germania 72:1-66

Verneau R (1915) Un mot au sujet des collections Hauser. L'Anthropologie 26:597-599

Vignard E (1945) Levalloisien et Moustérien d'Europe et d'Afrique. Leur place dans le quaternaire. Bulletin de la Société Préhistorique de France 42:155-168. https://doi.org/10.3406/bspf.1945.2007

Weinert H (1939) Andree, Julius: Der eiszeitliche Mensch in Deutschland und seine Kulturen. Zeitschrift fü Morphologie und Anthropologie 38:344-345

Weißmüller W (1995) Sesselfelsgrotte II. Die Silexartefakte der Unteren Schichten der Sesselfelsgrotte. Ein Beitrag zum Problem des Moustérien. Quartär-Bibliothek, vol 6. Saarbrückener Druckerei und Verlag, Saarbrücken

Werth E (1916a) Das Micoquien-Hauser in Deutschland. ZfE 48:89-92

Werth E (1916b) Hausers Micoquien. Korrespondenz-Blatt der Deutschen Gesellschaft für Anthropologie, Ethnologie und Urgeschichte 47:71-72

Werth E (1919) Die Kultur von La Micoque. Korrespondenz-Blatt der Deutschen Gesellschaft für Anthropologie, Ethnologie und Urgeschichte 50:10-12

Wetzel R (1935) Die Bocksteinschmiede im Lonetal, Markung Rammingen. Fundberichte aus Schwaben Neue Folge 8:16-20

Wetzel R (1944) Die Faustkeilfunde der Grabung Bocksteinschmiede. In: Jankuhn H (ed) Jahrestagungen. Bericht über die Kieler Tagung 1939. Forschungs- und Lehrgemeinschaft „Das Ahnenerbe“. Karl Wachholtz, Neumünster, pp 81-92

Wetzel R (1954) Quartärforschung im Lonetal. E\&G Eiszeitalter und Gegenwart Quart Sci J 4-5:106-141. https://doi.org/10.3285/eg. 04-5.1.10

Wetzel R, Bosinski G (1969) Die Bocksteinschmiede in Lonetal (Markung Rammingen, Kreis Ulm) vol Teil II: Tafeln. Veröffentlichungen des Staatlichen Amtes für Denkmalpflege Stuttgart Reihe A Vor- und Frühgeschichte, vol 15, 1st edn. Müller \& Graff, Stuttgart

Wetzel R, Völzing O, Gieseler W, Keller K (1941) Die Lontalforschung. Plan und Zwischenbericht. Jahresband der Wissenschaftlichen Akademie Tübingen des NSD-Dozentenbundes 2:79-130

Wiegers F (1920) Diluvialprähistorie als geologische Wissenschaft. Abbandlungen der Preosischen Geologischen Landesanstalt. Neue Folge, vol 84, Preußischen Geologischen Landesanstalt edn. Preußischen Geologischen Landesanstalt, Berlin

Wiegers F (1928) Allgemeine Diluvialprähistorie. Diluviale Vorgeschichte des Menschen, vol 1. Ferdinand Enke Verlag, Stuttgart

Wiegers F, Schuchhardt C, Hilzheimer M (1913) Eine Studienreise zu den paläolithischen Fundstellen der Dordogne. ZfE 45:126-160

Zamiatnin SN (1929) Station Moustérienne Ilskaya province de Kouban (Caucase du Nord). Rev Anthropol 7:282-295

Zotz LF (1939) Die Altsteinzeit in Niederschlesien. Verlag Kurt Kabitzsch, Leipzig

Zotz LF (1941) Die Altsteinzeitkunde auf der Jahrestagung 1939 der Forschungs- und Lehrgemeinschaft "Das Ahnenerbe". Quartär 12: $179-180$

Zotz LF (1951) Altsteinzeitkunde Mitteleuropas. Ferdinand Enke, Stuttgart

Publisher's note Springer Nature remains neutral with regard to jurisdictional claims in published maps and institutional affiliations. 